



\section{СИСТЕМА СТАТИСТИКИ КУЛЬТУРЫ ЮНЕСКО - 2009 (ССК)}

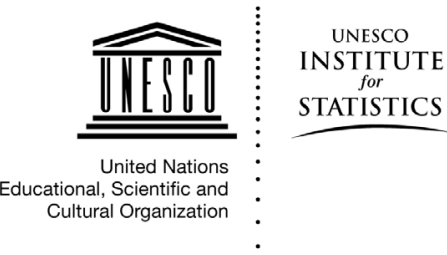




\section{ЮНЕСКО}

Решение о создании Организации Объединённых Наций по вопросам образования, науки и культуры (ЮНЕСКО) было утверждено 20 странами на Лондонской конференции в ноябре 1945 г. Оно вступило в силу 4 ноября 1946 г. В настоящее время в Организацию входит 193 страны-члена и 7 ассоциированных членов.

Главной целью ЮНЕСКО является укрепление мира и безопасности на земле путем развития сотрудничества между странами через образование, науку, культуру и коммуникации для содействия достижению всеобщего уважения и справедливости, главенства закона, соблюдения прав человека и основных свобод, утвержденных для народов мира без различия рас, полов, языков или религий Уставом Организации Объединенных Наций.

Для претворения в жизнь своих полномочий ЮНЕСКО выполняет пять основных функций: 1) проводит перспективные исследования в области образования, науки, культуры и коммуникаций в интересах будущего мира; 2) развивает, передает и распространяет знания путем исследований, подготовки и преподавательской деятельности; 3) определяет стандарты для подготовки и внедрения внутренних инструментов и нормативных рекомендаций; 4) благодаря техническому сотрудничеству стран-членов проводит экспертизу их политики и проектов развития; и 5) осуществляет обмен отраслевой информацией.

Руководящие структуры ЮНЕСКО расположены в Париже, Франция.

\section{Институт статистики ЮНЕСКО (ИСЮ)}

Институт статистики ЮНЕСКО (ИСЮ) является статистическим подразделением ЮНЕСКО и хранилищем всемирной статистической информации ООН в области образования, науки и техники, культуры и коммуникаций.

ИСЮ был образован в 1999 г. Он был создан для усовершенствования статистической программы ЮНЕСКО, а также для развития и своевременного распространения точных и политически значимых статистических данных, необходимых в постоянно усложняющейся и быстро меняющейся современной социальной, политической и экономической ситуации.

ИСЮ находится в Монреале, Канада.

Опубликовано в 2010 г.

UNESCO Institute for Statistics

P.O. Box 6128, Succursale Centre-Ville

Montreal, Quebec H3C 3J7

Canada

Тел.: (1514) 343-6880

Факс: (1 514) 343-5740

Адрес электронной почты: publications@uis.unesco.org

Веб-сайт: http://www.uis.unesco.org

ISBN 978-92-9189-085-9

Ref: UIS/TD/10-02

CUNESCO-UIS 2010 


\section{Предисловие}

Система статистики культуры ЮНЕСКО - 2009 (ССК) является итогом совместной работы Института статистики ЮНЕСКО (ИСЮ) и Сектора культуры ЮНЕСКО. Основанная на Системе статистики культуры ЮНЕСКО - 1986 (ССК), настоящая переработанная версия методологии статистики культуры ЮНЕСКО учла новые концепции, возникшие в области культуры после 1986 г., включая те из них, которые связаны с новыми технологиями, кардинально изменившими культуру и фрормы доступа к ней, нематериальным культурным наследием и развитием культурной практики и политики.

Культура играет ключевую роль во всех обществах мира, влияя на разные стороны жизни людей - от досуга до профессиональной деятельности. В последнее время роль культуры в процессе развития также стала важной политической проблемой. Тем не менее, сохранение и уважение самобытности каждой отдельной культуры, как и отличительных качеств других культур, представляет собой проблему, требующую урегулирования в глобальном масштабе.

Чтобы разработать конструктивную политику и иметь возможность определять и оценивать последствия ее применения, необходима достоверная информация. Учитывая это, ЮНЕСКО признала необходимость обновления Системы статистики культуры 1986 г., которая была основана на фрормальном и статичном представлении о культуре, что не отражает более широкий современный подход и приоритеты развивающихся стран. Кроме того, новая система предоставляет концептуальную базу и методологию, позволяющие получать и распространять сопоставимые в международном плане данные статистики культуры.

Эта пересмотренная версия является результатом всесторонних консультаций, проводившихся во всем мире на протяжении трех лет. Вклад в ее развитие внесли многие специалисты, ученые, статистики, страны-члены ЮНЕСКО и международные организации. Обширный и разносторонний вклад различных участников оказался неоценимым для создания этой методологии, открывшей новые широкие перспективы в изучении культуры и статистике культуры. ССК 2009 г. разработана в качестве методологии для международного и национального применения. Ее главная цель состоит в облегчении международных сравнений благодаря общему пониманию культуры, использованию унифицированных определений и международных социально-экономических классификаций.

За счет этого проекта ЮНЕСКО надеется стимулировать инвестиции в развитие статистики культуры. Страны-члены, международные и неправительственные организации остро нуждаются в данных и статистических материалах для того, чтобы лучше определять воздействие и актуальность культурной политики и программ. Мы верим, что Система статистики культуры - 2009 внесет вклад в более совершенное измерение социально-экономического значения культуры.

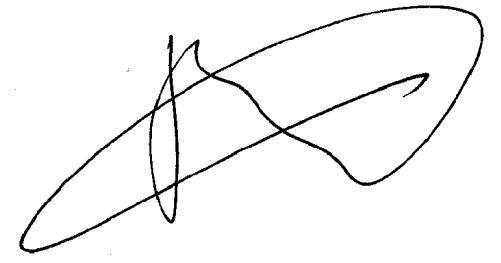

Хендрик Ван Дер Пол Директор Института статистики



Франсуаза Ривьер

Заместитель Генерального Директора по культуре 


\section{Выражение признательности}

Система статистики культуры ЮНЕСКО - 2009 (ССК) подготовлена Хосе Пессоа и Лидией Делумо из Института статистики ЮНЕСКО (ИСЮ) под общим руководством Саймона Эллиса. Она основана на первоначальном проекте, составленном для ИСЮ консультационной группой в состав которой входили Ричард Нэйлор и Пол Оуэнс (ВОР Consulting), Энди Пратт (Лондонская школа экономики) и Калвин Тейлор (Университет Лидса).

ССК является результатом проводившихся в разных странах консультаций со многими учеными, статистиками и экспертами в области статистики культуры, включая представителей многих министерств культуры, национальных статистических организаций и международных партнерских агентств. ИСЮ благодарит всех, кто внес вклад в ее подготовку, и выражает признательность коллегам из Сектора культуры ЮНЕСКО.

Особую благодарность за рекомендации и экспертные советы ИСЮ хотел бы выразить следующим членам рабочей группы ССК: Альфонсо Кастельяносу-Рибо (Председатель), Гиомар Алонсо Кано, Марте Бек-Домзальской, Элен Беилби-Оррин, Владимиру Бина, Ибтиссаму Эль-Жуни, Мате Ковачу, Виже Мадану, Гленну Масокоане, Лилиане ОртисОспино, Дж. П. Сингху и Дэвиду Тросби. 


\section{Аббревиатуры}

\begin{tabular}{|c|c|}
\hline $\begin{array}{l}\text { АНСКЗ } \\
\text { АНСПК } \\
\text { ОСБЗЭТВ }\end{array}$ & $\begin{array}{l}\text { Австралийская и новозеландская стандартная классификация занятости } \\
\text { Австралийская и новозеландская стандартная промышленная классификация } \\
\text { Организация стран Бенгальского залива в сфрерах экономического и } \\
\text { технического взаимодействия }\end{array}$ \\
\hline ПБ & Платежный баланс \\
\hline КФОУ & Классификация функций органов управления \\
\hline КИПЦ-ДХ & Классификатор индивидуального потребления домашних хозяйств по целям \\
\hline КЦНО & Классификация целей некоммерческих организаций \\
\hline КПВД & Классификатор продукции по видам деятельности, ЕС \\
\hline КОП & Классификация основных продуктов \\
\hline КУ & Коллективные услуги \\
\hline DCMS & Департамент культуры, СМИ и спорта Соединенного Королевства \\
\hline EBOPS & Расширенная классификация услуг в платежном балансе \\
\hline ССК & Система статистики культуры \\
\hline ICATUS & $\begin{array}{l}\text { Проект ООН - Международная классификация деятельности по статистике } \\
\text { используемого времени }\end{array}$ \\
\hline $\mathrm{HKH}$ & Нематериальное культурное наследие \\
\hline ИКТ & Информационно-коммуникационные технологии \\
\hline IIFB & Международный форум коренных народов по биологическому разнообразию \\
\hline MOT & Международная организация труда \\
\hline ИУ & Индивидуальные услуги \\
\hline MCKO & Международная стандартная классификация образования \\
\hline MCK3 & Международная стандартная классификация занятий \\
\hline MCOK & Международная стандартная отраслевая классификация \\
\hline ЭГЛ & Экспертная группа руководатва ЕС по статистике культуры \\
\hline ЦРТ & Цели развития тысячелетия, ООН \\
\hline $\mathrm{HCY}$ & Национальное статистическое управление \\
\hline ОЭСР & Организация экономического сотрудничества и развития \\
\hline КДЕС & Классификация видов экономической деятельности Европейского Сообщества \\
\hline NAICS & Североамериканская система классификации отраслей \\
\hline NAPCS & Североамериканская система классификации продуктов \\
\hline НЕПАД & Новое партнерство в интересах развития Африки \\
\hline СПК & Стандартная промышленная классификация \\
\hline CKMT 4 & Стандартная классификация международной торговли, версия 4 \\
\hline $\mathrm{CHC}$ & Система национальных счетов \\
\hline TCC & Сателлитный отчет по туризму \\
\hline ИСЮ & Институт статистики ЮНЕСКО \\
\hline ЮНКТАД & Конференция ООН по торговле и развитию \\
\hline UNPFII & Постоянный форум ООН по вопросам коренных народов \\
\hline $\mathrm{COOOH}$ & Статистический отдел ООН \\
\hline BOT & Всемирная организация по туризму \\
\hline Воис & Всемирная организация интеллектуальной собственности \\
\hline BTO & Всемирная торговая организация \\
\hline n.e.s. & Не указано в другом месте \\
\hline n.e.c & Не классифицировано в других рубриках \\
\hline n.f.d. & Определение дано не полностью \\
\hline
\end{tabular}





\section{Оглавление}

Предисловие ...............................................................................................................ii

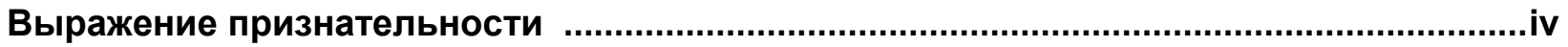





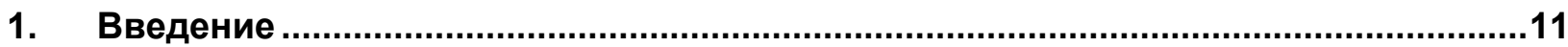



1.2 ПОЛИТИЧЕСКИЕ УСЛОВИЯ ПЕРЕСМОТРА СИСТЕМЫ СТАТИСТИКИ КУЛЬТУРЫ..............13

1.3 ЦЕЛЬ И ОСНОВНЫЕ ЗАДАЧИ ПЕРЕСМОТРА СИСТЕМЫ СТАТИСТИКИ КУЛЬТУРЫ ............16

2. Система статистики культуры: понятия и структура ….......................................17

2.1 ПЕРЕСМОТР СИСТЕМЫ СТАТИСТИКИ КУЛЬТУРЫ: НОВЫЙ ПОДХОД ….......................17

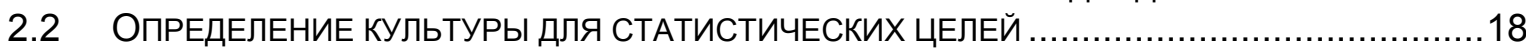

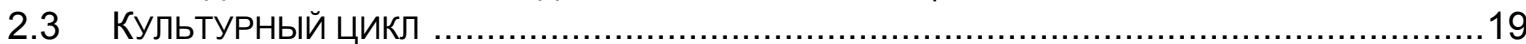



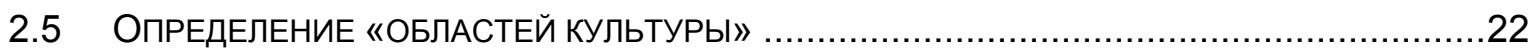

3. Статистика культуры: измерение экономических параметров .............................33

3.1 ИСПОЛЬЗОВАНИЕ МЕЖДУНАРОДНЫХ КЛАССИФИКАЦИЙ ПРИ ИЗМЕНЕНИИ

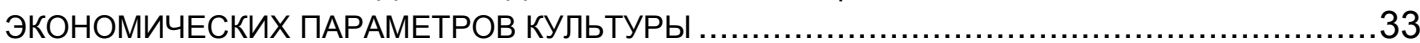

3.2 ОПРЕДЕЛЕНИЕ КУЛЬТУРНОЙ ПРОИЗВОДСТВЕННОЙ ДЕЯТЕЛЬНОСТИ И ПРОДУКТОВ КУЛЬТУРЫ: ПРИМЕНЕНИЕ КЛАССИФИКАЦИИ ОСНОВНЫХ ПРОДУКТОВ (КОП) И МЕЖДУНАРОДНОЙ СТАНДАРТНОЙ ОТРАСЛЕВОЙ

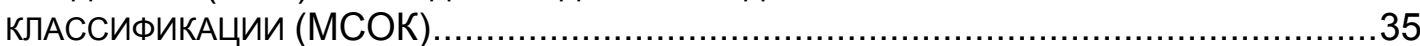

3.3 МЕЖДУНАРОДНАЯ ТОРГОВЛЯ КУЛЬТУРНЫМИ ТОВАРАМИ И УСЛУГАМИ:



3.4 ЗАНЯТОСТЬ В ОБЛАСТИ КУЛЬТУРЫ: ПРИМЕНЕНИЕ МЕЖДУНАРОДНОЙ

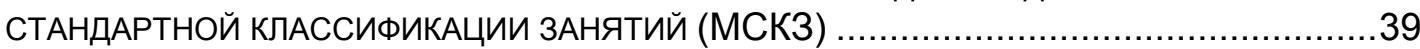

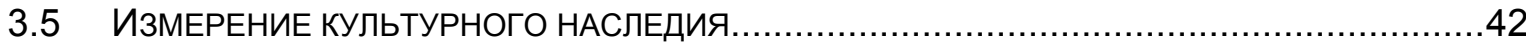

4. Статистика культуры: измерение социальных параметров ................................44

4.1 ИЗМЕРЕНИЕ УЧАСТИЯ В КУЛЬТУРНОЙ ДЕЯТЕЛЬНОСТИ .........................................44

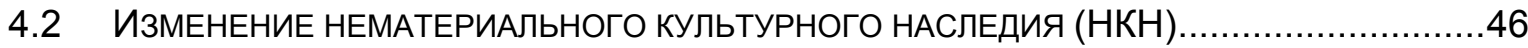

5. Сбор данных: таблицы международных категорий ..............................................51

ТАБЛИЦА 2. КУЛЬТУРНАЯ ПРОИЗВОДСТВЕННАЯ ДЕЯТЕЛЬНОСТЬ, ТОВАРЫ И УСЛУГИ, ОПРЕДЕЛЯЕМЫЕ НА ОСНОВЕ КАТЕГОРИЙ КОП 2 И МСОК 4 ........................52

ТАБЛИЦА 3. МЕЖДУНАРОДНАЯ ТОРГОВЛЯ КУЛЬТУРНЫМИ ТОВАРАМИ И УСЛУГАМИ, ОПРЕДЕЛЯЕМЫМИ НА ОСНОВЕ КАТЕГОРИЙ ГАРМОНИЗИРОВАННОЙ СИСТЕМЫ (ГС) 2007 Г.

ТАБЛИЦА 4. ЗАНЯТОСТЬ В ОБЛАСТИ КУЛЬТУРЫ, ОПРЕДЕЛЯЕМАЯ НА ОСНОВЕ КАТЕГОРИЙ МСКЗ 08

ТАБЛИЦА 5. ОПРОСЫ ПО ИСПОЛЬЗОВАНИЮ ВРЕМЕНИ НА ОСНОВЕ КАТЕГОРИЙ ICATUS .78

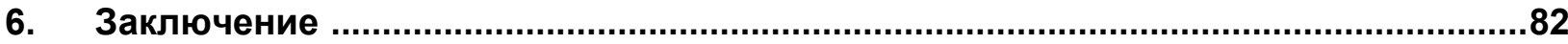

6.1 ПРОБЛЕМЫ, СВЯЗАННЫЕ СО СБОРОМ ДАННЫХ ПО КУЛЬТУРЕ $\ldots \ldots \ldots \ldots \ldots \ldots \ldots \ldots \ldots \ldots . . . . . . . \ldots 2$

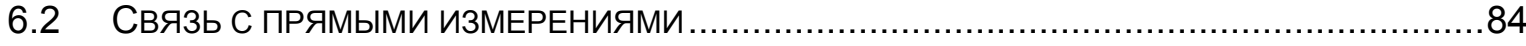

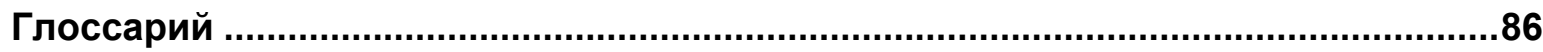

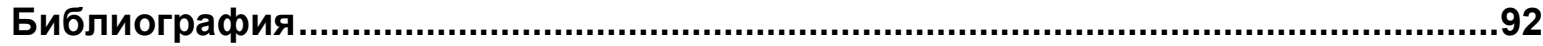





\section{Краткое содержание}

\section{Цель Системы статистики культуры ЮНЕСКО (ССК)}

Система статистики культуры (ССК) является инструментом для организации статистики культуры как на национальном, так и на международном уровнях. Она исходит из концептуальной основы и общепринятого понимания культуры, которые позволяют проводить измерения широкого спектра проявлений культурного творчества независимо от конкретных экономических и социальных способов их производства. Благодаря применению стандартных определений она также позволяет получать сопоставимые в международном плане данные.

Система является результатом широкого консультационного процесса, проходившего в глобальном масштабе. Она создана на основе ССК - 1986 (UNESCO, 1986) и переработана в ходе творческих/культурных обсуждений, связанных с воздействием глобализации на производство и распространение продуктов культуры, отражая современную практику и вопросы интеллектуальной собственности.

Благодаря большей доступности экономических данных и наличию многих применяющихся международных систем классификации более полное развитие в ССК получило измерение экономических параметров культуры. Однако, такое же значение имеют социальные параметры культуры, включая участие в культурной жизни и нематериальное культурное наследие. Хотя здесь предложены исходные элементы для их измерения, в этом направлении требуется дальнейшая работа.

ССК является инструментом классификации, включающим действующие ныне международные классификационные системы, такие как Международная стандартная отраслевая классификация (МСОК) - в отношении деятельности, связанной с культурным производством, Классификация основных продуктов (КОП) - в отношении благ и услуг в области культуры, Международная стандартная классификация занятий (МСКЗ) - в отношении занятости в области культуры, Гармонизированная система описания и кодирования товаров (ГС) - в отношении международных потоков товаров культуры, и Проект ООН - Международная классификация деятельности по статистике используемого времени (ICATUS) - в отношении участия в культурной жизни. Результатами стали инструмент и методология, предназначенные для применения на международном и национальном уровнях в качестве основы для организации сбора и распространения статистических данных в области культуры. В ней сделана попытка отразить максимально широкий спектр деятельности, связанной с производством, распределением и использованием культуры.

\section{Определение культуры}

ЮНЕСКО определяет культуру как комплекс особых духовных, материальных, интеллектуальных и эмоциональных характеристик общества или социальной группы, которые охватывают не только искусство и литературу, но также образ жизни, уклад совместного проживания, системы ценностей, традиции и верования (ЮНЕСКО, 2001). Хотя непосредственно измерить эти верования и ценности можно не всегда, измерению поддаются связанные с ними поведение и обычаи. В качестве таковой Система статистики культуры ЮНЕСКО определяет культуру через идентификацию и измерение поведения и обычаев, определяющихся верованиями и ценностями общества или социальной группы. 
Области культуры, выделенные в ССК, представляют собой общий комплекс экономической (такой, как производство товаров и услуг) и социальной (такой, как участие в культурной жизни) деятельности, которая традиционно рассматривается в качестве «культурной». Кроме того, Смежные области включают другие виды экономической и социальной деятельности, которые можно рассматривать как «отчасти культурные», или, как их чаще называют в отличие от «чисто культурных» - «развлечения и досуг».

Хотя в качестве исходного пункта большинство нынешних стандартов, используемых для разработки этих определений, исходят из экономической перспективы, интерпретация итоговой области не ограничена исключительно экономическими сторонами культуры, она распространяется на все аспекты этой области. Иначе говоря, определение для измерения «представления» включает все представления, независимо от того, любительские они или профессиональные, исполняются ли они в концертном зале или в деревне под открытым небом.

Кроме того, в системе выделены три «сквозные» области, измеряемые поперек спектра отраслевых областей. Образование и подготовка кадров, Архивирование и хранение и Нематериальное культурное наследие характеризуются как сквозные культурные области; включение каждой из этих трех областей чрезвычайно важно для измерения полного объема культурного творчества.

\section{Измерение культуры: прагматический подход}

Способность стран собирать и распространять данные по статистике культуры значительно различается в зависимости от их политических приоритетов, опыта в области статистики, а также людских и финансовых ресурсов. Система разработана для гибкого и приспособленного к национальному уровню развития применения.

Кроме того, система создана на основе концепции модели культурных циклов области культуры, что помогает нам понять соотношение между различными культурными процессами. Цикл отражает всю совокупность обычаев, деятельности и необходимых ресурсов, требуемых для трансформации идей в блага и услуги культуры, которые, в свою очередь, достигают потребителей, участников или пользователей.

Система включает в себя все современные значимые международные классификационные системы и стандарты, чтобы максимально увеличить сопоставимость данных и способность использования существующих опросов для измерения культуры. Эти классификационные системы предоставляют странам всеобъемлющую структуру для сбора и распространения данных по культуре. Она также служит в качестве руководства по измерению культурной деятельности, благ и услуг с использованием основополагающей базовой структуры ССК. Страны, обладающими большими возможностями в области статистики, могут собирать более детальные данные, используя более точные или специально разработанные статистические инструменты, отражающие их политические приоритеты в области культуры.

Система не дает определений или предложений относительно конкретных показателей. Разработка системы показателей в области культуры и сопутствующих показателей является следующим важным шагом как на национальном, так и на международном уровнях. 


\section{1. Введение}

Настоящая система заменяет Систему статистики культуры ЮНЕСКО - 1986 (ССК) (UNESCO, 1986). Со времени разработки первой ССК ЮНЕСКО возникло много разных подходов к определению или измерению культуры, а общественные и технические сдвиги изменили место культуры в мире.

Международная система статистики культуры призвана максимально увеличить международную сопоставимость в тех случаях, где это уместно и возможно. Потребность в данных на национальном уровне определяется необходимостью разработки конструктивной политики, чтобы страны имели информацию о своем положении по сравнению с другими странами региона или мира.

Система предоставляет концептуальную основу для оценки экономического и социального вклада культуры. Она является инструментом, призванным помогать странам-членам в организации сбора и распространения данных их статистики в области культуры. Она даст возможность собирать как национальные, так и межнациональные статистические данные в области культуры для использования ЮНЕСКО, многими международными организациями и глобальным сообществом пользователей данных.

Эта новая система призвана быть гибкой, а не ограничительной, и способствовать развитию сопоставимости. ССК имеет целью оказывать странам поддержку в создании их собственной системы культуры путем отбора основных областей, являющихся формообразующими для их статистики культуры. Кроме того, каждая страна, применяя соответствующие определения ССК по областям, обеспечит международную сопоставимость собственных данных.

\section{1 Обоснование}

После 1986 г. изменилось восприятие роли культуры в социально-экономической сфере. Bce большее признание со стороны организаций и специалистов по оказанию помощи играет роль связи между культурой и развитием. Культура все в большей степени рассматривается и как средство развития, т.е., двигатель развития и поддержки экономического прогресса, и как результат развития, т.е., смысл нашего существования. Она может создавать источники дохода за счет туризма, ремесел и памятников материальной культуры, внося свой вклад в устойчивое развитие региона и страны. Признано, что культура оказывает влияние на поведение людей, их вклад в процесс экономического развития, общественное развитие и рост благосостояния (UNESCO, 1995).

Потенциальное воздействие культуры на социально-экономическое развитие стран можно суммировать следующим образом:

- Общественное культурное достояние можно успешно использовать для поддержки устойчивого развития на местах через его экономическое воздействие в качестве культурных отраслей и их вклада в общественное и культурное возрождение.

- Культура предоставляет женщинам и детям возможности для участия в производственной деятельности, внося свой вклад в достижение равенства полов, самоуважение и участие в общественной жизни. Продуманная политика в области культуры может помочь сохранить традиционные обычаи и отражать потребности 
таких социально ущемленных групп населения, как женщины или коренные народы. Женщины являются хранительницами опыта, передают культурные ценности и хранят культурные традиции (UNESCO, 1995).

- Определенные отрасли культуры в основном приспособлены для малого или семейного предпринимательства, соответствующего потребностям развития на местах.

Некоторые причины повышения значения культуры отражают лежащие в их основе долгосрочные тенденции; другие определяются событиями недавнего прошлого. Во многих регионах мира увеличилось благосостояние и возрос чистый доход, что привело к росту систематических расходов на культурную деятельность и продукты. Это значит, что культура скорее является важной частью цикла экономического воспроизводства, чем роскошью или предпочтительным продуктом, приобретаемым с целью размещения избыточных средств. Культурное потребление возросло, спектр продуктов расширился, и теперь «продукт» стал носителем информации для большинства типов культурного опыта.

Эти долгосрочные тенденции усилились за счет двух более поздних связанных с этим явлений:

- Культурные отрасли, которые ранее были разделены за счет аналоговых систем производства (кинофильмы, телевидение, фотография и печать), теперь оказались объединенными в цифровом формате, где во многих случаях их больше нельзя разделить. Цифровая технология коренным образом изменила способ производства и распространения культурной продукции. Прежде всего, это относится к Интернету, все шире используемому для распространения различных продуктов культуры через один и тот же носитель информации.

- Глобализация привела к интернационализации потоков товаров и услуг, а также к общемировому обмену идеями, людьми и капиталом. Культурное многообразие и взаимное проникновение культур создали новые продукты, новые обычаи и множественные идентичности.

По сравнению с периодом до-цифровых технологий современные устройства позволяют быстрое коммерческое использование даже таких «единичных» культурных продуктов, как песня. Это изменение привело к сдвигам в соотношении экономических возможностей между культурными продуктами, воспроизводимыми с помощью цифровых технологий - и лучше распространяемыми коммерчески, - и теми, которые обычно продать труднее (Barrowclough and Kozul-Wright, 2006).

В результате область культуры в некоторых развитых странах имеет большее экономическое значение (хотя бы с точки зрения занятости), чем некоторые ранее сложившиеся отрасли промышленности (например, горное дело, производство автомобилей и т.п.), и вносит значительный вклад в поступления от экспорта. Хотя экономическое воздействие культуры в развивающемся мире в настоящее время сказывается в области занятости значительно меньше, экспортные доходы здесь могут быть непропорционально высокими. В связи с этим роль культуры в качестве инструмента развития пересматривается и отмечается, что она оказывает потенциально позитивное влияние на рост и развитие в развивающемся мире (Barrowclough and Kozul-Wright, 2006). 
Нынешние системы политики в области культуры основаны на существующем соотношении сил, предпочтений и ресурсов периода, предшествующего цифровым технологиям. Поэтому новые формы культурной продукции составляют для них серьезные проблемы - особенно в таких областях, как сохранение культурного наследия, интеллектуальная собственность и разнообразие, - и делают их менее эффективными в достижении поставленных целей. Например, если некоторые фрормы музыкального творчества имеют больший коммерческий успех, другие культурные формы, не пользующиеся преимуществами цифрового воспроизведения и распространения, нуждаются в продолжении государственной поддержки для сохранения существующего в области культуры положения. Равным образом, эти перемены могут привести к переоценке этой ситуации.

Новые фрормы культурного производства также привели к созданию новой области политических действий в сфере культуры, связанной с деятельностью различных подгрупп культурной индустрии. Их еще иногда называют творческими отраслями (см. Раздел 2.2). Они имеют много общего с распространенным ранее понятием культурной индустрии, которое обычно употребляется при характеристике коммерческой стороны деятельности в области культуры. Однако настоящая система исходит из более широкого представления о сильной и полной жизни взаимозависимости между всеми типами деятельности в области культуры - как в государственном, так и в частном секторе. Например, исполнители могут получать плату как из государственных, так и из частных средств - точнее говоря, им могут платить или не платить за работу на еженедельной основе, что существенно затрудняет определение их принадлежности к государственному или частному сектору. Если сосредоточить внимание на исполнении, можно рассчитывать на то, что система будет отражать изменчивость границ и оценивать взаимно усиливающие друг друга элементы этих двух компонентов.

Такие изменения в создании, производстве, распространении и потреблении культуры означают, что область культуры выросла в относительном и абсолютном выражении, нередко опережая традиционные области экономики. В связи с быстрыми темпами изменений и новаторским характером культурной продукции для полной оценки уровня и глубины этих изменений требуются большие по объему и лучшие по качеству данные. Как отмечается ниже, область культуры развивается неравномерно. Это ведет к возникновению ряда чувствительных для общества проблем и противоречий между коммерческой и некоммерческой деятельностью, традицией и современностью, а также международным аспектом культуры и ее состоянием у коренных народов.

\section{2 Политические условия пересмотра системы статистики культуры}

Со времени появления ССК - 1986 (UNESCO, 1986) возросло значение культуры в государственной политике, что объясняется рядом причин:

- Увеличение международной торговли продуктами культуры. Это привело к серьезным последствиям в области прав на интеллектуальную собственность в прямом смысле слова (на их создание, обладание и использование), а также в более широком плане культурной самобытности и обладания ею (например, нематериальное культурное наследие).

- Рост и усиление рыночных позиций нескольких транснациональных компаний, действующих в области культуры. Организация культурного производства на многих рынках благоприятствует монополизации; в связи с этим существует «право первой руки», сосредоточенное почти целиком в развитых странах. Тем не менее, Интернет 
также позволяет развивать рыночные возможности распространения за пределами этих каналов, но значительно расширяет пиратскую деятельность.

- Юридические и политические институты регулирования и развития культуры были созданы до бурного всплеска индустрии культуры. В качестве таковых эти институты не имеют достаточных возможностей для решения нынешних проблем. Основным при разработке соответствующей политики является наличие четкой исходной базы. Жизненно важную составляющую отражения положения в области культуры представляют собой статистические источники, необходимые для анализа современных культурных процессов.

- Политика в области культуры как политика «индустрии культуры» позволяет развивать отраслевой подход и экономическую перспективу. Вследствие этого политика в области культуры должна учитывать индустрию культуры.

- Существует сложная взаимозависимость между общественной и частной областями, выходящая за рамки простого дуализма. Например, некоторые коммерческие культурные мероприятия оказывают влияние на тенденции политики в области культуры. Системы, ограниченные дуалистическим подходом, будут становиться в этом плане все менее состоятельными.

- На региональном уровне политическое стремление к инвестициям в индустрию культуры демонстрируют две инициативы, направленные на снижение уровня бедности:

- Инициатива Паро (BIMSTEC, 2006) стран-членов ОСБЗЭТВ гласит: «Культурная индустрия может внести вклад в борьбу с нищетой, она показала себя действенным инструментом общественных преобразований и возрождения местных общин, особенно среди беднейших слоев населения как в сельской местности, так и в городских трущобах».

- План действий Найроби в культурных и творческих отраслях в Африке, разработанный на первой сессии конференции министров культуры Афрриканского союза (African Union, 2005) и принятый на второй сессии конференции министров культуры Африканского союза в Алжире (African Union, 2008) содержит аналогичные выводы и рекомендации. Его основная цель состоит в улучшении условий жизни и работы африканских деятелей культуры, вносящих вклад в развитие местной культуры и содействующих ее развитию в Африке. К числу других задач относятся облегчение защиты, организации, производства, маркетинга, распространения, демонстрации на выставках и охраны культурных и творческих отраслей в Африке; а также создание в Африке условий для того, чтобы там можно было в полном объеме получать выгоду от будущих стратегий развития, технологий и рынков как в области культуры, так и в других отраслях (AU, 2008). Кроме того, в плане действий подчеркивается значение сбора статистических данных о культурных и творческих отраслях. 
С 1986 г. значительно усилились внимание и потребность в проведении более активной политики в отношении культурного разнообразия. Конвенция ЮНЕСКО об охране и поощрении разнообразия форм культурного самовыражения также отражает такое развитие событий (UNESCO, 2005a). Учитывая растущее значение творческого вклада в экономику, следует иметь в виду, что культурное разнообразие является основным условием развития творчества и новаторских начинаний. Как отмечал Дэвид Тросби: «...принципы поддержания культурного разнообразия определяются тем обстоятельством, что разнообразие идей, верований, традиций и других проявлений художественного и культурного творчества ведет к возникновению широкого спектра культурных услуг, которые существенно отличаются от услуг, предоставляемых их отдельными составляющими... культурное разнообразие вносит весомый вклад в динамику художественной и культурной жизни, которая, в свою очередь, оказывает стимулирующее воздействие на экономику».

Культурное разнообразие - это многоплановая в политическом отношении сфера с различными истоками, где внимание уделяется разным территориальным уровням: внутригосударственному, межгосударственному или транснациональному. В последнем случае стремление к активной политике в области культурного разнообразия имеет ряд взаимосвязанных аспектов:

- В общем плане возник растущий спрос на продукты культуры, создаваемые в развивающихся странах, а в отдельных случаях на их создание совместно с продуктами развитых стран. Но при переговорах о доходах от культурного экспорта развивающиеся страны зачастую находятся в гораздо менее выгодном положении, чем развитые; отчасти это объясняется отсутствием местных институциональных возможностей, но большую роль здесь также играет абсолютное засилье монополистического сектора развитых стран;

- Размывание границ между (в основном западными) представлениями о высокой и популярной культуре и между Западом и «всеми остальными»; и

- Коммерциализация продуктов кустарных промыслов и eе роль в стратегии экономического развития развивающихся стран.

В результате этих изменений возник целый ряд проблем, в числе которых, возможно, больше всего дискуссий вызывает вопрос о правах на интеллектуальную собственность. По мере того, как культура все в большей степени рассматривается в качестве товара, степень защиты, которой должны быть обеспечены отдельные лица, чьи идеи используются, определяется системой прав (и определением тех прав, которые могут иметь отдельные производители). Уже много говорилось о конкретных проблемах в этой области, связанных с копированием или кражей, прежде всего, в связи со стремлением крупных корпораций защитить свои активы. В то же время, в тех областях культуры, которые не связаны с коммерциализацией, четкое определение прав отсутствует, что делает их уязвимыми для кражи. Эта проблема существует в развивающихся странах, причем о ней часто не говорят, что ставит под угрозу разнообразие культурного творчества. В частности, по этой причине в Конвенции ЮНЕСКО 2005 г. об охране и поощрении разнообразия форм культурного самовыражения (UNESCO, 2005a) подчеркивается двойственная природа (экономическая и культурная) культурной деятельности, благ и услуг, «которая передает самобытность, ценности и значения» и их уязвимость. В Декларации ЮНЕСКО о культурном разнообразии 2001 г. (UNESCO, 2001), культурное разнообразие характеризуется как «источник обмена, новаторства и 
творчества [...] столь же необходимый человечеству, как биологическое разнообразие природе... это один из источников развития, понимаемого не просто как экономическое развитие, но и как средство достижения более удовлетворительного интеллектуального, эмоционального, морального и духовного существования». Двумя принципами этих инструментов являются равный доступ ко всем выражениям культуры и устойчивое развитие.

ССК 1986 г. (UNESCO, 1986) была разработана странами-членами ЮНЕСКО, которые в основном принадлежали к развитым государствам. В пересмотренной ССК принимаются во внимание потребности развивающихся стран. В частности, в ней рассматриваются уместность и возможность включения таких элементов, как нематериальное культурное наследие и неформальная экономика, а также проблемы культурного разнообразия. В системе 1986 г. полностью или должным образом не были отражены некоторые виды культурной деятельности, такие как народные промыслы и роль образования.

\section{3 Цель и основные задачи пересмотра системы статистики культуры}

Настоящая система создает концептуальную основу, обеспечивающую взаимопонимание, которое позволит проводить международные сравнения полного цикла деятельности по производству, распространению и использованию культуры. Для достижения этой цели в системе использованы следующие основополагающие принципы:

- Создание концептуальной основы, охватывающей полный спектр культурного творчества, независимо от конкретного социально-экономического способа его реализации;

- Обращение к полному охвату культурного творчества (культурные формы, практика, продукты и процессы) включая новые фрормы их создания и потребления (индустрия культуры и культурная составляющая интеллектуальной собственности), а также культурная практика, не связанная с индустрией культуры (нематериальное культурное наследие);

- Использование по мере возможности категорий, присущих таким международным классификациям, как Классификация основных продуктов (КОП), Гармонизированная система описания и кодирования товаров (также известная как Гармонизированная система - ГС), Международная стандартная отраслевая классификация (МСОК) и Международная стандартная классификация занятий (МСКЗ); и

- Помощь странам в развитии их собственных, отражающих местные условия систем статистики, но имеющих общие базисные параметры, позволяющие проводить международные сравнения и выявлять их общие характеристики. 


\section{2. Система статистики культуры: понятия и структура}

\section{1 Пересмотр системы статистики культуры: новый подход}

Проблема развития новой системы статистики культуры состоит в разработке подхода, который преодолел бы определенные противоречия и двойственность, присущие спорам о политике в области культуры, прежде всего о том, как культуру измерять. Использованный в настоящей работе подход направлен на преодоление противоречий, возникших в результате трех типов двойственности, присущих политике в области культуры:

i) Сфера культуры (социально-экономическая). Этот подход основан на понимании того, как создается и передается культурный замысел. Такой подход к производству и распространению культуры неизбежно влечет за собой осознание того, как она сопрягается с социальными и экономическими процессами. Культура не вычленяется и не отделяется от общества и экономики. Многие элементы культуры, включая те, которые не имеют связи с рынком, могут быть отслежены через такие показатели, как участие в культурной жизни, потраченное время или общественный капитал. Многие другие процессы, связанные с производством и передачей культуры, имеют отношение к экономическим операциям, которые поддаются измерению.

ii) Тип функционирования (государственный - частный). При производстве и передаче культуры такой подход не учитывает субсидирование и тип фуннционирования (частный сектор, государственный сектор или гражданское общество). К трем источникам финансирования культуры относятся: і) общественное (в основном из средств правительства или общественных институтов), предоставляемое в прямой (субсидии и гранты) или косвенной (освобождение от налогов) форме; іi) частное (из рыночных источников); и іiі) некоммерческих организаций или доноров. На основании имеющихся данных нельзя составить четкой картины этих трех источников фринансирования культуры. Рабочая группа по расходам и финансированию культуры признает чрезвычайную сложность получения сопоставимых и упорядоченных данных об общественном фринансировании культуры в европейских странах (European Commission, 2001). Сравнение очень затрудняется наличием различных структур общественного фринансирования (централизованных или нет) и методологиями, применяемыми в разных странах.

В системе акцент ставится на отношениях, связях и обменах, пересекающих эти границы в области культуры.

iii) Степень институционализации (формальная - неформальная). При таком подходе допускается, что производство и распространение в области культуры имеют место в рамках как фрормальной, так и неформальной экономики и общественной жизни. Неформальное культурное производство характерно как для развитых, так и для развивающихся стран. Однако, если культурное производство развивается в рамках неформальной экономики или натуральных отношений, ему можно дать оценку. Данный подход предназначен для справедливого охвата всего процесса культурного творчества, его выражения и значения (см. Раздел 2.3). 
Возрастающая специализация разделения труда во многих отраслях культуры привела к четкому различию задач между «созданием» культуры и ее «использованием». Тем не менее, в других отраслях, таких как народные промыслы, эти различия выражены в меньшей степени, поскольку создатели кустарных произведений искусства могут сами придумывать, создавать и демонстрировать/продавать свои произведения, тем самым сочетая функции или стирая различия в разделении труда. В силу этого народные умельцы сами могут быть участниками нескольких этапов культурного производственного цикла.

Логика, лежащая в основе пересмотра настоящей системы, включает три аспекта:

- Отраслевой охват (включая области, считающиеся культурными) и его глубину (включая исполнителей, артистов, вспомогательный персонал и продукты, без которых исполнители и артисты не могут обойтись);

- Стремление движения системы к прямым показателям; и

- Способность давать сопоставимые в международном плане оценки. Вместе с тем, важно, чтобы в данной системе «всех не стригли под одну гребенку». В ее рамках необходимо учитывать как местную специфику и разнообразие, так и возможности для сравнения.

\section{2 Определение культуры для статистических целей}

Восприятие культуры, лежащее в основе пересмотра Системы статистики культуры, основано на определении, данном во Всеобщей декларации о культурном разнообразии ЮНЕСКО, где сказано: «Культуру следует рассматривать как комплекс особых духовных, материальных, интеллектуальных и эмоциональных характеристик общества или социальной группы, которые охватывают не только искусство и литературу, но также образ жизни, уклад совместного проживания, системы ценностей, традиции и верования» (UNESCO, 2001). Такое определение культуры тесно связано с теми способами, которыми общества, группы и общины определяют свою самобытность.

При разработке определения культуры для статистических целей в ССК учитывались два основных положения:

- Концепция «области культуры». Определение области культуры можно начать с ряда отраслей (в совокупности обычно называемых культурной индустрией), поскольку фрормально их можно определить, используя существующие международные классификации. Область может также охватывать все виды культурной деятельности под соответствующими названиями, включая нефрормальную и общественную деятельность. Например, статистика кино может включать посещаемость коммерческих кинотеатров и коммерческое производство кинофильмов, а также домашнюю съемку и просмотр фрильмов. Такую неформальную и общественную деятельность, составляющую основную часть культурной деятельности, труднее определить используя современные статистические инструменты, и это требует иного методологического подхода в рамках ССК. С точки зрения системы область включает все виды связанной с ней деятельности - как экономические, так и общественные. 
- Дебаты «творческий - культурный». Во многих странах эти отрасли нередко называют "творческими», но значительная часть компаний, действующих в таких отраслях, на деле не обязательно являются таковыми. Определение и измерение творчества само по себе является предметом ожесточенных дискуссий. Творческие отрасли обычно имеют более широкие рамки, чем традиционные художественные области, включая, например, отрасли ИКТ или исследования и разработки. В системе эта проблема рассматривается через включение некоторых конкретных творческих отраслей (дизайн и реклама) в качестве отдельной области.

\section{3 Культурный цикл}

Культурный цикл охватывает все различные этапы создания, производства и распространения культуры. При таком подходе культуру можно рассматривать как продукт комплекса схожих процессов. Эта деятельность может быть институционализированной или нет, может развиваться под руководством государства или самостоятельно. Широкий подход к этой отрасли, включающий неформальную, любительскую и не связанную с рынком деятельность, здесь определяется как «область», указывая на то, что концепция охватывает как общественные и не связанные с рынком, так и экономические, связанные с рынком виды деятельности.

Развитие подхода, основанного на областях, позволяет обозначить процессы производства и распространения культуры в соответствии с производственным циклом. Как явствует из анализа национальных и региональных классификаций первоначального Консультационного исследования ПБ (UNESCO-UIS, 2006а), в ряде стран-членов ЮНЕСКО уже применяется концепция культурного цикла. Однако в некоторых ситуациях потенциал этой концепции используется не полностью и/или она применяется непоследовательно. Подход с позиций культурного цикла помогает осмыслить как на деле производится культурная продукция и происходит культурная деятельность, он выходит за рамки простой группировки областей.

Проблема надежной и устойчивой системы статистики культуры состоит в охвате тех процессов, которые позволяют создавать, распространять, получать, использовать, критиковать, понимать и сохранять культурные достижения. Был разработан ряд подходов, позволяющих полнее выявлять все стороны деятельности, необходимой для производства и распространения культуры. На их основе была сделана попытка свести производственный цикл к пяти этапам (Схема 1), хотя, естественно, разные культурные формы имеют различные производственные циклы и потому не все из них равным образом вовлечены в каждую стадию процесса.

Как и в ССК - 1986 (UNESCO, 1986), культурный цикл включает пять стадий, которые не совсем одинаково представлены скорее в циклической, нежели в иерархической модели, чтобы подчеркнуть мысль о том, что эти отношения могут быть достаточно сложными и проявляться скорее в качестве системы.

1. Создание: замысел, авторские идеи и содержание (например, скульпторов, писателей, дизайнерских компаний), а также производство единичной продукции (например, кустарные промыслы, изящные искусства).

2. Производство: воспроизводимые культурные фрормы (например, телевизионные программы), а также специальные инструменты, инфраструктура и процессы, используемые при их реализации (например, производство музыкальных инструментов, издание газет). 
3. Распространение: доставка обычно массово воспроизводимых продуктов культуры потребителям или распространителям (например, оптовая и розничная продажа и аренда музыкальных записей и компьютерных игр, распространение кинофильмов). При цифровом распространении некоторые товары и услуги направляются непосредственно от создателя к потребителю.

4. Демонстрация/восприятие/передача: относятся к месту потребления и предоставлению живого и/или непосредственного культурного творчества аудитории через раздачу или продажу доступа к потреблению/участию в ходе ограниченных по времени культурных мероприятий (например, организация и проведение фестивалей, посещение оперных и других театров, музеев). Передача связана с передачей знаний и навыков, которые не могут иметь отношения к коммерческим сделкам, и часто происходит в неформальной обстановке. Она включает передачу нематериального культурного наследия от поколения к поколению.

5. Потребление/участие: деятельность аудитории и участников по потреблению продуктов культуры, участие в культурных мероприятиях и приобретение культурного опыта (например, чтение книг, танцы, участие в карнавалах, прослушивание радиопередач, посещение картинных галерей).

\section{Схема 1. Культурный цикл}

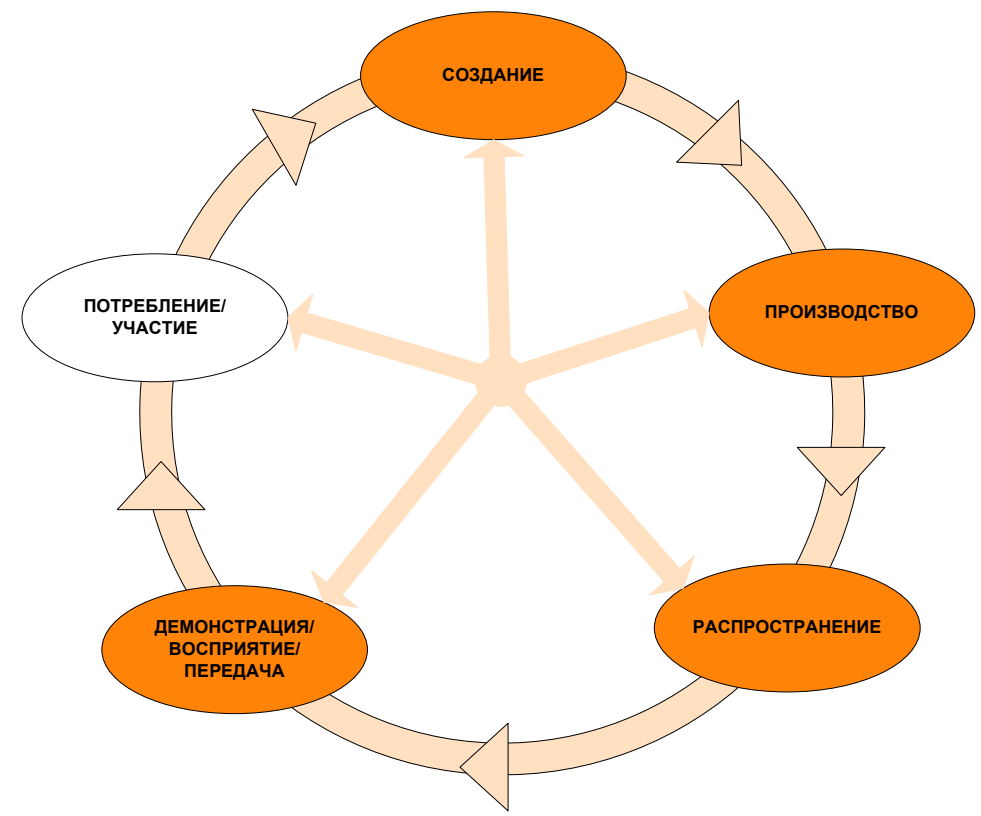

Термин культурный цикл в данном случае уместен, поскольку он предполагает наличие взаимосвязи между этими типами деятельности, включая процесс обратной связи, за счет которой деятельность, связанная со спросом (потребление), вдохновляет на создание новых продуктов и произведений культуры. Модель помогает абстрактному осмыслению культурного производства и распространения; ее следует отчасти рассматривать в плане сенсибилизации модели. На практике некоторые ее этапы могут быть объединены. Например, если музыканты могут сочинять (создавать) и исполнять (производить/ распространять), то драматурги пишут (создают), но редко играют на сцене (производят/ распространяют). Индивидуальный ремесленник, который добывает сырье (неформальный вклад ресурсов), при создании произведений культуры опирается на традицию (неформальная подготовка) и продает свои изделия на обочине дороги 
(неформальное распространение и розничная продажа) сам неформально воплощает весь производственный цикл. Понимание того, какая часть процесса измерена, составляет важный элемент в разработке последующей государственной политики вмешательства в процесс производства культуры.

Для некоторых типов культурной деятельности этот процесс может начинаться на любой стадии культурного цикла, некоторые фразы которого могут быть объединены или вообще отсутствовать, как например, в случае культурного наследия, где можно сказать, что его создание относится к прошлому. Большая часть деятельности, связанная с мероприятиями нематериального культурного наследия, приходится на этапы «демонстрация и передача» и «потребление/участие».

Система структуры цикла уделяет внимание новым формам производства, в основном связанным с новыми технологиями. Их использование привело к созданию взаимозависимости между различными функциями, и со временем эти новые фооры культурных процессов могут эти функции объединить. Например, благодаря таким технологиям, как YouTube или блоги, можно одновременно создавать и потреблять.

Культурный цикл помогает определить происхождение культурной продукции в области общественных отношений. Подход с позиций культурного цикла не уделяет внимания мотивации, определяющей создание продуктов культуры - будь то прибыль или передача унаследованных культурных ценностей. Поскольку культурная деятельность и ее участники находятся в постоянном движении между рыночными и нерыночными отношениями, следует признать ту роль, которую играют и те, и другие, а также трудности, связанные с их измерением.

Культурный цикл не обременен суждениями о том, насколько «культурен» каждый отдельный его этап. Скорее здесь важно понять и отследить весь объем деятельности и необходимых ресурсов для трансформации идей в культурные блага и услуги, которые, в свою очередь, достигают потребителей, участников или пользователей. Произведение искусства (будь то картина, предмет народного творчества или спектакль) бессмысленно без системы ценностей и производственной системы, придающей ему ценность/значимость. Так, если какая-то страна решит, что некая территория должна быть признана центром национального значения или выдающегося культурного наследия, ее руководство примет решение о мобилизации необходимых средств на развитие туризма, транспорта, ее сохранности и гостиниц, что позволило бы ему обеспечить доходы от ее посещения.

Культурный цикл также имеет пространственное измерение. Некоторые виды деятельности могут быть сосредоточены в одном месте, регионе или стране, в то время как другие - разбросаны по всему миру. Точно определить природу такого членения можно лишь эмпирическим путем, и это обстоятельство имеет важные последствия как для регулирования культурной отрасли, так и в вопросе о том, как извлекать из этого прибыль (экономическую и социальную). Столь же важным пространственным компонентом культуры является перемещение, при котором люди отрываются от культурной среды своего происхождения в связи с миграцией. Глобализация увеличила возможности таких перемещений и обострила проблему культурной ассимиляции, в результате чего могут усилиться противоречия и ощущение чего-то экзотического и чуждого.

Эмпирические данные (количественные и качественные), которые можно использовать для анализа цикла (частично получаемые на базе системы статистики культуры) не всегда доступны по всем странам. Для тех из них, где выделяются средства на сбор 
информации, модель показала, что уровень культурного вклада является достаточно значительным. Однако его подлинную значимость - как и информации, на основе которой разрабатывается политический курс, - можно будет оценить, когда станут доступны сравнительные данные по странам и регионам.

Любая конкретная политика в области культуры не нуждается в полном культурном цикле. Однако при выработке политического курса следует принимать в расчет, что даже небольшое/ограниченное вмешательство в рамках всего цикла может привести к значительным последствиям.

\section{4 Охват области культуры}

Обзор некоторых систем классификации культуры всего мира (UNESCO-UIS, 2006a) свидетельствует о наличии согласия по вопросу о том, что культура является продуктом коллективного творчества, составляющие которого поддаются определению. Тем не менее, в этом вопросе существуют некоторые неясности:

i) Отсутствует согласие при определении того, как эти типы деятельности группировать в более высокие категории областей; и

ii) Нет единой точки зрения на то, какие функции следует включать в анализ области культуры.

Отчасти расхождения по пункту (i) являются отражением местных культурных различий. Вместе с тем они связаны и с отсутствием четкой исходной модели или логики анализа, что составляет суть пункта (ii).

Однако, требование последовательного и логичного подхода при пересмотре системы статистики культуры является не единственным. Здесь следует принимать в расчет и более прагматичные вопросы, связанные с:

- Применением - возможностью применить определения видов деятельности и категорий в рамках статистических систем классификации, будь то Классификация основных продуктов (КОП), Международная стандартная отраслевая классификация (МСОК), Международная стандартная классификация занятий (МСКЗ) или другие международные классификации.

- Политикой - обеспечением применения системы (которая была бы полезна) при поддержке и одобрении стран, многие культурные институты которых представляют могущественные интересы, при том условии, что они будут в состоянии «увидеть себя» в рамках системы.

\section{5 Определение «областей культуры»}

Для измерения области культуры и определения входящих в нее категорий необходимо представлять себе широту ее охвата. Исходя из задач настоящей системы, основанной на прагматическом подходе, данное выше рабочее определение культуры основано на общем определении, приведенном выше (Раздел 2.2).

Прагматическое определение культуры, используемое в ССК, исходит из представления культуры по областям, что соответствует целям измерения культурной деятельности, благ и услуг, создаваемых в ходе промышленных и непромышленных процессов. Культурные блага и услуги связаны с художественными, эстетическими, символическими и духовными ценностями. Характеристики культурных благ и услуг отличаются от других продуктов, поскольку система их оценки, включающей невоспроизводимые качества, связана с их восприятием или удовольствием (Throsby, 2001). 
Культурные блага передают идеи, символы и уклады жизни, некоторые из которых могут быть защищены авторскими правами. Культурные услуги не представляют собой культурных товаров как таковых, но обеспечивают их производство и распространение. Например, культурные услуги включают лицензионную деятельность и другие услуги, связанные с авторскими правами, деятельность по распространению аудиовизуальной продукции, содействие развитию исполнительских видов искусства и культурных мероприятий, а также услуги в области культурной информации и хранению книг, записей и произведений искусства (в библиотеках, информационных центрах и музеях). Большая часть этих товаров и услуг охраняется авторским правом.

Культурная деятельность воплощает в себе или передает произведения культуры независимо от коммерческой ценности, которую они могут иметь. Эта деятельность может иметь самостоятельное значение или вносить вклад в производство культурных благ и услуг (UNESCO-UIS, 2005).

В отличие от Системы 1986 г. (UNESCO, 1986) определение областей культуры основывается на иерархической модели, включающей основные и связанные с ними культурные области. Основные области включают культурную деятельность, блага и услуги, имеющие отношение к разным стадиям модели культурного цикла. Связанные с ними области имеют отношение к более широкому определению культуры, имеющему отношение к общественной жизни и развлечениям. Эти области являются взаимоисключающими, поэтому музыка, например, выделяется в единую категорию. В отличие от предыдущей системы нематериальное культурное наследие теперь получило сквозное определение, в то время как в ССК 1986 оно частично входило в категорию «общественных услуг».

Области культуры ССК, отраженные на Схеме 2, представляют собой общеизвестный комплекс связанных с культурой отраслей производства, деятельности и практики, которые можно сгруппировать следующим образом:

- А: Культурное и природное наследие;

- Б: Представления и празднества;

- В: Изобразительное искусство и ремесла;

- Г: Книги и пресса;

- Д: Аудиовизуальные и интерактивные средства; и

- Е: Дизайн и творческие услуги

- Нематериальное культурное наследие (сквозная область)

Эти области считаются культурными. Они также представляют собой минимальный комплекс культурной деятельности, по которому ЮНЕСКО намерена просить страны собирать сопоставимые данные. Это позволит определить параметры охвата области культуры, а также даст представление о ее структуре.

Кроме того, сюда включены еще три сквозные области, поскольку они играют важную роль в культурном цикле производства и передачи культуры. Они относятся к числу сквозных, поскольку применимы ко всем культурным и связанным с ними областям:

- Образование и подготовка кадров

- Архивы и хранение

- Оборудование и сопутствующие материалы 
Схема 2. Области системы статистики культуры



ОБРАЗОВАНИЕ И ПОДГОТОВКА КАДРОВ

АРХИВЫ и ХРАНЕНИЕ

ОБОРУДОВАНИЕ И СОПУТСТВУЮЩИЕ МАТЕРИАЛЫ

\section{ДОПОЛНИТЕЛЬНЫЕ}

ОБЛАСТИ

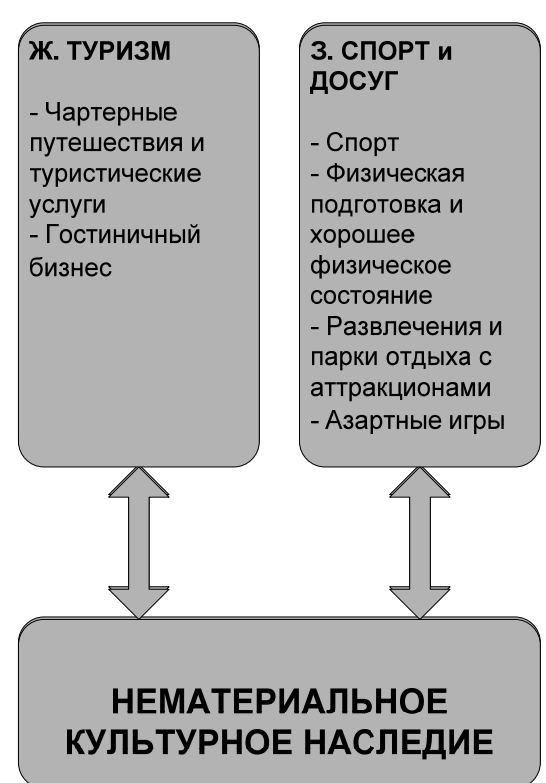

ОБРАЗОВАНИЕ И ПОДГОТОВКА КАДРОВ

АРХИВЫ и ХРАНЕНИЕ

ОБОРУДОВАНИЕ И СОПУТСТВУЮЩИЕ МАТЕРИАЛЫ 
Чтобы избежать двойного счета, каждый вид деятельности в системе следует классифицировать лишь единожды, даже несмотря на то, что логически некоторые виды деятельности распространяются более чем на одну область. Например, музыка попадает под рубрики «Представления и празднества» и «Аудиовизуальные средства», поскольку может звучать как в живом исполнении (Представление), так и в записи (Аудиовизуальные средства). Однако в ССК приоритет отдается скорее самому предмету, чем форме, в которой может проявляться его культурное содержание. Кроме того, значительная часть культурной области не может быть произвольно отделена в рамках статистической классификации от других видов исполнительских искусств.

\section{Культурные области}

Культурные области ССК определяются следующим образом:

\section{А. Культурное и природное наследие}

Область Культурное и природное наследие включает следующие разделы: музеи, археологические и исторические территории (включая территории археологических раскопок и памятников), культурные ландшафты и природное наследие.

Природное наследие распространяется на предметы, памятники, группы строений и территории, имеющие различную ценность, включая символическое, историческое, художественное, эстетическое, этнографическое или антропологическое научное или общественное значение.

Культурные ландшафрты представляют собой сочетание результатов природных процессов и человеческой деятельности, которые отражают продолжительные и тесные связи между людьми и их природным окружением (UNESCO, 2007).

Природное наследие охватывает национальные черты, геологические и фризикогеографические образования и распространяется на области, составляющие места обитания видов животных и растений, находящихся под угрозой исчезновения, представляющих ценность с точки зрения науки, охраны природы или естественной красоты. Оно распространяется на природные парки и заповедники, зоопарки, аквапарки и ботанические сады (UNESCO, 1972).

Деятельность, связанная с культурным и природным наследием, включает управление ткрриториями и собраниями, имеющими историческое, эстетическое, научное, экологическое и общественное значение. К этой же категории относится хранение и архивирование в музеях и библиотеках.

Музей определяется как «некоммерческое постоянно действующее учреждение на службе общества и развития, открытое для публики, которое приобретает, хранит, исследует, описывает и экспонирует объекты материального и нематериального культурного наследия человечества и среды его обитания в целях образования, изучения и получения удовольствия» (ICOM, 2007). К другим фрормам музеев, включенным в эту область, относятся музеи живой истории, в которых находятся предметы, все еще используемые для ритуалов и священных церемоний общинами, и виртуальные музеи, представленные в электронной форме на компакт-дисках или на сайтах в Интернете. 


\section{Б. Представления и празднества}

Представления и празднества включают все виды непосредственно проводимых культурных мероприятий.

Исполнительские искусства включают как профессиональную, так и любительскую деятельность, такую как театр, танцы, опера и кукольный театр. Кроме того, к ней относится проведение культурных мероприятий - фестивалей, празднеств и ярмарок, которые происходят на местах и могут носить неформальный характер.

Музыка в этой области определяется во всей совокупности, безотносительно к формату. В качестве таковой она охватывает живую музыку, музыкальные записи, цифровую музыку, включая загрузку музыки в сеть и из сети, а также музыкальные инструменты.

\section{В. Визуальные искусства и художественные промыслы}

Визуальные искусства представляют собой художественные фрормы, относящиеся к созданию визуальных по природе произведений. Они предназначены для воздействия на зрительное восприятие и могут иметь многие формы. Признано также, что некоторые современные виды изобразительного искусства могут включать междисциплинарные формы искусства, такие как «виртуальное искусство», в таком случае они относятся к области Д - Аудиовизуальные и интерактивные средства.

Область Визуальные искусства $и$ художественные промыслы включает такие изобразительные искусства, как картины, рисунки, скульптуры, художественные промыслы и фотография. В эту область также входят коммерческие помещения, где выставляются такие произведения искусства, - коммерческие художественные галереи.

В ССК принято определение художественных промыслов или кустарных продуктов, данное Международным торговым центром (МТЦ) и ЮНЕСКО, и гласящее: «эти продукты произведены ремесленниками либо полностью вручную, либо с помощью ручных инструментов, или даже механическими средствами, но лишь в том случае, если непосредственный ручной вклад ремесленника остается основной составляющей готового изделия. Особая природа кустарных продуктов определяется их характерными чертами, которые могут носить утилитарный, эстетический, художественный, творческий, связанный с культурой, декоративный, функциональный, традиционный, религиозный и общественно символический и значимый характер» (UNESCO-ITC, 1997).

ЮНЕСКО (UNESCO-ITC, 1997) определило шесть крупных категорий кустарных продуктов, исходя из используемых при их создании материалов: корзины/плетеные изделия/изделия из растительных волокон; кожаные изделия; металлические изделия; гончарные изделия; текстильные изделия и изделия из дерева. В пособии также указаны дополнительные категории, включающие кустарные изделия из материалов, присущих лишь определенным регионам или редким и трудным в обработке материалам, таким как камень, стекло, слоновая кость, кость, раковины, перламутр и т.д. Другие дополнительные категории выделяются в тех случаях, когда одновременно применяются различные материалы и технологии производства украшений, ювелирных изделий, музыкальных инструментов, игрушек и произведений искусства. Многие изделия художественных промыслов производятся промышленным способом; тем не менее, продукты, имеющие традиционный характер (узор, дизайн, технология или материал), рассматриваются как часть ССК. Современные художественные промыслы включены не в Визуальные искусства и художественные промыслы, а в область Е - Дизайн и творческие услуги. 


\section{Г. Книги и пресса}

В этой категории представлены все типы печатных материалов: книги, газеты и периодические издания. Она остается такой же, как была в СCK 1986 (UNESCO, 1986), но теперь в нее включены электронные или виртуальные фрормы изданий, такие как Интернет-газеты, электронные книги и цифровое распространение книг и материалов прессы. К этой же области относятся библиотеки - как фризические, так и виртуальные, а также книжные выставки-ярмарки.

Печать обычно не включается в культурные классификации или определения творческих отраслей и сама по себе не является культурной деятельностью. Тем не менее, при использовании модели производственного цикла печать может быть включена как часть производственной функции издательского дела. Поэтому ССК включает печатное дело в той его части, которая связана с конечным использованием преимущественно культурного назначения. Трудность состоит в попытке проведения различий между этими видами печатной деятельности при использовании существующих систем статистической классификации. Обычно печать, связанная с издательской деятельностью, включается в основную область Книги и пресса как производственная фрункция издательского дела, а другие печатные издания - коммерческие и технические каталоги или оперативная полиграфрия - исключаются. ССК рекомендует помещать эту связанную с печатью деятельность в разделе оборудования и сопутствующих материалов.

\section{Д. Аудиовизуальные и интерактивные средства}

Основными элементами этой области являются передачи радио и телевидения, включая передачи в Интернете, кино и видеофильмы и интерактивные средства. Интерактивные средства охватывают видеоигры и новые формы культурного выражения, главным образом реализующиеся через сеть или компьютер. Они включают онлайновые игры, сетевые порталы и сайты для деятельности, связанной с такими общественными сетями, как Facebook, и подкастинг в Интернете, в частности, YouTube. Тем не менее, программное обеспечение Интернета и компьютеров относится к инфраструктуре или инструментам, поэтому, говоря о содержании продукции интерактивных средств, их следует отнести к сквозной области Оборудование $u$ сопутствующие материалы.

Важными областями деятельности являются интерактивные средства и программное обеспечение. Если конечное использование многих продуктов и услуг интерактивных средств информации (компьютерные и видеоигры, интерактивный Интернет и мобильные средства связи) имеет культурное содержание, о создании программного обеспечения этого сказать нельзя. Интерактивные средства рассматриваются в ССК как часть области Аудиовизуальные и интерактивные средства. На деле это зависит от применяемой системы классификации и ее способности четко отличать деятельность, связанную с интерактивными средствами, от основного потока деятельности, связанной с программным обеспечением и телекоммуникациями. Классификация основных продуктов (КОП) позволяет определить некоторые, но не все интерактивные средства. Когда тип деятельности не может быть четко определен в рамках КОП или при применении более широких видов классификации, их следует включать в сквозную область Оборудование $и$ сопутствующие материалы.

Интерактивные средства определяются как взаимодействующие в тех случаях, если (1) два или более объектов оказывают воздействие друг на друга; (2) пользователь может оказать воздействие на объект или окружающую его среду (пользователи видеоигр); (3) они требуют активного вовлечения пользователя; или (4) существует двустороннее 
воздействие вместо одностороннего или простой причинно-следственной связи (Canadian Heritage, 2008).

Видеоигры и их развитие (разработка программного обеспечения) также включены в эту категорию, поскольку представляют собой интерактивную деятельность.

\section{Е. Дизайн и творческие услуги}

В ССК 1986 (UNESCO, 1986) область Дизайн и творческие услуги отсутствовала. Она охватывает виды деятельности, товары и услуги, связанные с творческим, художественным и эстетическим дизайном предметов, строений и ландшафта.

Область включает дизайн одежды, графический дизайн и дизайн интерьера, ландшафтнный дизайн, архитектурные и рекламные услуги. Архитектура и реклама являются частью основных культурных областей, но только в качестве услуг. Основная цель архитектурных и рекламных услуг состоит в предоставлении творческих услуг или промежуточного вклада в создание конечного продукта, характер которого не всегда является культурным. Например, конечным продуктом творческих рекламных услуг может быть коммерческая реклама, которая сама по себе не является культурным продуктом, но создается в результате определенной творческой деятельности. Чтобы избежать двойного счета, некоторые виды дизайнерской деятельности было решено отнести к другим категориям, а не к области Е. В частности, строения, включенные в раздел культурного наследия, уже рассматриваются в области А - Культурное и природное наследие, а содержание дизайна интерактивных средств включено в область Д Аудиовизуальные и интерактивные средства.

\section{Сквозные области}

Хотя эти области могут быть выделены в самостоятельные, они рассматриваются как сквозные, поскольку могут быть применимы и в других областях культуры.

Область Нематериальное культурное наследие рассматривается как полностью относящаяся к культуре, в то время как остальные сквозные области, а именно: Архивы и хранение, Образование и подготовка кадров и Оборудование и сопутствующие материалы считаются отчасти культурными, поскольку они содержат элементы $и$ деятельность, имеющие отношение к культуре, и потому представляют интерес и достаточно важны в культурном отношении для ССК.

Нематериальное культурное наследие (сквозная культурная область)

В Конвенции ЮНЕСКО об охране нематериального культурного наследия (UNESCO, 2003b), нематериальное культурное наследие (НКН) определяется как «практика, представления, творчество, знания, опыт, - а также связанные с ними инструменты, объекты, предметы и культурное пространство, - которые признаются частью своего культурного наследия сообществами, группами, а в некоторых случаях отдельными лицами» (ст. 2).

НКН одновременно представляет собой традицию и современность. Оно «передается от поколения к поколению» и «постоянно воспроизводится сообществами и группами как реакция на среду обитания, взаимодействие с природой и историей и наделяет их чувством самобытности и целостности» (ст. 2).

Уникальной чертой НКН является то, что его можно определить как таковое, когда сообщество признает его в качестве части своего наследия. Иначе говоря, в его выражении или практике нет ничего такого, что позволило бы посторонним 
(правительствам, статистикам, исследователям) определить его как нематериальное культурное наследие. Поэтому идентификация, как и определение нематериального культурного наследия, остается прерогативой общин, групп, а в некоторых случаях отдельных лиц, которые создают, сохраняют и передают это наследие.

Нематериальное культурное наследие не может рассматриваться как отдельная область культурной деятельности или производства; скорее оно находит отражение во всех культурных областях ССК. Например, НКН может отражаться в художественных промыслах или исполнительских искусствах. Поэтому оно представлено в качестве сквозной области (см. Схему 2). К числу нескольких неполных областей, в которых проявляется нематериальное культурное наследие, относятся: а) устная традиция и творчество, включая язык как средство передачи нематериального культурного наследия; б) исполнительские искусства; в) общественная практика, ритуалы и празднества; г) знания и практика, касающиеся природы и вселенной; д) традиционные кустарные промыслы.

За созданием этой новой области НКН лежат многие годы исследований, проводившихся ЮНЕСКО в области ффункций и ценностей культурного творчества и практики. Они помогли создать новый подход к пониманию, защите и уважению нашего культурного наследия, обеспечив признание со стороны тех общин и групп, которые идентифицируют, воплощают, воссоздают и передают нематериальное культурное наследие.

Архивы и хранение (сквозная культурная область)

Архивирование представляет собой сбор и хранение памятников культуры (движимых и нематериальных объектов) в целях сохранения для будущего, демонстрации и повторного использования (например, сохранение исторических территорий и строений, архивов звукозаписи и рисунков). Хранение связано с охраной или сохранением, а также организацией определенного культурного и природного достояния.

Деятельность по архивированию и хранению имеет место в каждой области культуры (авторская рукопись, первое представление произведения, программа концерта/выставки). Архивный материал также может служить исходным пунктом, воодушевляющим на новые творческие достижения. Архивированные и сохраняемые элементы произведений изящных искусств, кустарных промыслов, дизайна, архитектуры и аудиовизуальных отраслей, в свою очередь, также могут способствовать творческому вдохновению для создания новых произведений. Например, сохранение (и демонстрация) исторических зданий; хранение (и демонстрация) в музеях и художественных галереях картин, скульптур, ювелирных изделий и широкого спектра других произведений искусства, ценность которых состоит прежде всего в атрибутах их дизайна (во всем - от мебели до автомобилей); в то время, как в архивах хранятся такие оригинальные документы, как рукописи, фоотографии, книги, кинофильмы и записи радиопередач.

Образование и подготовка кадров (сквозная культурная область)

ССК рассматривает образование не во всей его полноте, а лишь в той части, где оно является средством передачи культурных ценностей или навыков. Обучение поддерживает развитие, понимание и восприятие культуры, включая критику (например, художественных и балетных школ, литературоведение). Образование - это процесс, благодаря которому культура передается от поколения к поколению. Благодаря ему люди также учатся ценить или составлять ценностные суждения (т.е. критиковать) культурную деятельность или произведения искусства. Образование - это процесс общения, в ходе которого осмысливается культура и развивается творческое начало, которое может поставить под сомнение существующие культурные нормы. 
Образование и подготовка кадров в сфере культуры помогают человеку приобрести навыки для творческих замыслов и воплощения в жизнь продуктов культуры. Они учат людей ценить результат потребления культурных благ и услуг или получать общественные преимущества от участия в культурной деятельности. Кроме того, образование служит для передачи нематериального культурного наследия в формальных или неформальных системах, формирующих самобытность сообщества. Таким образом, образование и подготовка кадров играют важную роль во всех областях культуры и на всех этапах культурного цикла.

Используя переменную образования, странам рекомендуется применять Международную стандартную классифрикацию образования (МСКО97) (UNESCO-UIS, 2006d) при сборе данных или их расположении в системе классификации МСКО97 при обработке данных, чтобы их было проще сопоставлять в международном плане. Странам также следует использовать классификационную структуру по областям образования МСКО97.

Оборудование и сопутствующие материалы (сквозная культурная область)

Эта область охватывает «инструменты продуктов культуры и культурной деятельности». Продукты культуры (блага и услуги) в разных ее областях непосредственно касаются культурного содержания, в то время как оборудование и сопутствующие материалы связаны с сопутствующими отраслями, а также с дополнительными услугами (если они хотя бы частично относятся к культурному содержанию), которые облегчают или делают возможным создание, производство и распространение благ и услуг в области культуры, и потому включаются в эту область. Сюда же включены компьютерные и информационные технологии, поскольку они являются инструментами, с помощью которых создаются, производятся и распространяются в Интернете многие продукты и услуги, а также развиваются интерактивные средства информации.

Причина отличия этой категории от продуктов и деятельности, включенных в области А $\mathrm{E}$, состоит в необходимости определения элементов, характер которых не целиком относится к культуре, но их можно использовать для производства и воплощения в жизнь товаров или деятельности в области культуры, и они необходимы для существования этих продуктов культуры.

Культурологические исследования выделяются в каждой области в соответствующих категориях.

\section{Дополнительные области}

Спорт и досуг, а также туризм не всегда рассматриваются как культурная деятельность, хотя в них содержатся элементы культуры. Иначе говоря, они представляют собой деятельность, которая может иметь культурный характер, но основные ее составляющие не относятся к культуре. Как таковые они отнесены в ССК к дополнительным.

\section{Ж. Туризм}

Туризм качественно отличается от других областей культуры, поскольку его нельзя просто классифицировать как отрасль в традиционном смысле, т.е. измеряемую либо с рыночных, либо с производственных позиций. Скорее туризм легче понять как деятельность, определяемую потребительским спросом, и в качестве таковой тесно связанную со всеми другими областями в рамках индустрии культуры, поскольку каждая из них содержит деятельность, регулярно осуществляемую туристами. Поэтому в настоящее время также существует хорошо разработанная международная методология по измерению экономического воздействия туризма, частично основанная на развитии сателлитных отчетов по туризму (TCC) (см. также: Eurostat, OECD, UN and UNWTO, 2001). 
В идеале ССК должна была бы учитывать такие культурные параметры туризма, как деятельность, связанную с культурным туризмом, духовным туризмом и экологическим туризмом. Поскольку признанной в международном плане дефиниции культурного туризма не существует, ССК предлагает следующее определение: «специальные экскурсии для непосредственного ознакомления с иными культурами и территориями с целью достаточно близкого знакомства с живущими там людьми, их образом жизни, культурным наследием и искусством, которое дает возможность в истинном свете увидеть их ценности и условия исторического развития, включая практическое знакомство с существующими различиями» (Steinberg C, 2001). Он также может принимать фрормы духовного или экологического туризма. Эта деятельность относится к культурной и включается в области А, Б, В или Нематериальное культурное наследие. Например, если турист посещает памятники древних цивилизаций или концерты, эта деятельность автоматически относится к той или иной области культуры.

В соответствии с подходом ТСС, статистика туризма измеряет потребность туристов в товарах и услугах (международных или отечественных). Они включают расходы на путешествие, размещение и другие затраты. Однако, она должна включать и данные, не связанные с деньгами, касающиеся численности туристов и целей путешествий. Поэтому, чтобы избежать двойного счета, туристическая деятельность включается в эту область (например, туристические справочники и агентства), а также в деятельность вне рамок индустрии культуры, где в основном сосредоточен основной объем деятельности туристов (например, размещение).

\section{3. Спорт и досуг}

Спорт

Спорт в ССК рассматривается в широком понимании, поскольку включает организованный и/или состязательный спорт, а также фризическую подготовку и хорошее физическое состояние и развлечения, связанные с фризической культурой. В ССК отражены как профессиональный, так и любительский спорт.

В некоторых странах определенные виды спорта тесно связаны с их культурной самобытностью, поскольку спорт нередко ассоциируется с общественными структурами и традициями. Примером в данном случае может служить борьба сумо в Японии. В других странах спорт считается лишь активным досугом или - как в большинстве случаев - им занимаются немного интенсивнее, чем фризическими упражнениями. Более того, одинаковые виды спорта в разных странах могут восприниматься по-разному. В некоторых классификациях (European Commission, 2002), присутствие зрителей на спортивных состязаниях или просмотр спортивных событий по телевизору рассматриваются как культурная деятельность, в то время как профессиональный спорт не обязательно относится к культуре. Эти важные различия в подходах и распространенное отношении к тому, что именно участие, а не сам спорт рассматривается как «продукт или отрасль культуры» определяют нашу классификацию спорта в качестве дополнительной деятельности.

Досуг

К этой же области относится и досуд, который определяется как деятельность, связанная с получением удовольствия или расслаблением, которая развлекает, забавляет или возбуждает. Она охватывает азартные игры, развлечения и парки отдыха с аттракционами, а также другие виды проведения досуга. Она исключает виды досуга, связанные с физической культурой, которые относятся к спорту. 
Азартные игры

Азартные игры учитывают заведения, главным образом предоставляющие услуги в области азартных игр, такие как казино, букмекерские конторы на ипподромах, помещения для игры в лото, залы игровых автоматов, лотерейные агентства и внеипподромный тотализатор (ABS, 2001).

В некоторых странах, таких как Соединенное Королевство, лотерея, в частности, является крупнейшим источником финансирования культуры. Это объясняет, почему азартные игры составляют часть ССК, а не включаются в дополнительные области.

Развлечения и парки отдыха с аттракционами

Эта деятельность включает развлечения, парки отдыха с аттракционами и другие виды аттракционов. 


\section{3. Статистика культуры: измерение экономических параметров}

Данный раздел посвящен измерению некоторых экономических параметров культурной деятельности с использованием существующих международных систем классификации. Экономические аспекты культуры, охватываемые ССК, представляют все виды деятельности, услуг и товаров, производимых по отраслям культуры промышленным или кустарным способом. Результат такого подхода отражается в определении каждой области культурной деятельности, благ и услуг или занятости через категории, связанные с функциями культурного цикла. Это отражено в Разделе 5, где представлены списки всех значимых категорий по соответствующим классификациям.

\section{1 Использование международных классификаций при измерении экономических параметров культуры}

В этом разделе рассматривается использование существующих инструментов сбора инфрормации для получения данных по статистике культуры. Такими инструментами являются существующие международные системы классификаций, позволяющие получать и анализировать сопоставимые в международном плане данные по культуре. Большая часть этих международных классификаций представляют собой комплексные системы, в рамках которых можно собирать и излагать экономические данные в фрормате, предназначенном для целей экономического анализа, принятия решений и разработки политического курса.

Имеющиеся административные данные и выборочные опросы (индивидуальные, компаний и домашних хозяйств) можно использовать для получения широкого спектра данных о культуре, которые помогают определить вклад культуры в национальную экономику по отношению к ВВП и тенденции как занятости в сфере культуры, так и потребления культуры. В настоящее время экономические данные о культурной продукции и занятости собираются большинством национальных статистических учреждений путем перегруппировки общих данных экономической статистики, получаемых на базе существующих экономических опросов с использованием стандартных международных статистических классификаций (см. Раздел 5). Данные обычно собираются на основе опросов, проводимых в компаниях и на предприятиях, опросов, связанных с домашними расходами, регистрационных списков предприятий, статистических исследований заработков, выборочных обследований рабочей силы и переписей населения. Хотя эти инструменты сбора данных не предназначены специально для сбора информации о культуре, они, тем не менее, позволяют анализировать выборочные типы культурной и связанной с ней деятельности.

В настоящий раздел включено использование четырех международных экономических классификаций. Подробный список приведен в Разделе 5 настоящего документа:

і) Международная стандартная отраслевая классификация (МСОК 4) - для определения культурной производственной деятельности или отраслей (Раздел 5, Таблица 2);

ii) Классифрикация основных продуктов (КОП 2) - для определения благ и услуг в области культуры (Раздел 5, Таблица 2);

iii) Гармонизированная система описания и кодирования товаров 2007 (ГС 2007) (Раздел 5, Таблица 3) и Расширенная классификация услуг в платежном балансе (Раздел 3, Таблица 1) - для определения международной торговли культурными благами и услугами; 
iv) Международная стандартная классификация занятий (МСКЗ 08) - для определения занятости в области культуры (Раздел 5, Таблица 4).

Многие инструменты для сбора данных и опросы, проводимые на национальном и международном уровнях, используют эти системы классификации. Обычно международные системы классификации согласуются с национальными или региональными, такими как Североамериканская система классификации отраслей (NAICS), Австралийская и новозеландская стандартная промышленная классификация (АНСПК) или Классификация видов экономической деятельности Европейского Сообщества (КДЕС). Североамериканская система классификации продуктов (NAPCS) и Классификатор продукции по видам деятельности (КПВД) для Европы можно использовать для классификации по типам продуктов. Для согласования двух любых классификаций следует использовать существующие таблицы соответствия ${ }^{1}$.

Другой широко распространенной экономической моделью является Система национальных счетов (СНC). СНС 08 также совместима с категориями МСОК 4 и КОП 2. Кроме того, здесь используется Классификация расходов в соответствии с целевой классификацией функций органов управления (КФОУ); Классификатор индивидуального потребления домашних хозяйств по целям (КИПЦ-ДХ) и Классификация целей некоммерческих организаций, обслуживающих домашние хозяйства (КЦНО). Виды культурной деятельности, определяемой с использованием этих классификаций, представлена ниже.

а) КФОУ используется для оценки государственных расходов на культуру. Основные категории культуры выделяются указанными ниже кодами:

08.1 .0 - услуги в области развлечений и спорта (ИУ)

08.2.0 - услуги в области культуры (ИУ)

08.3.0 - услуги в области вещания и издательского дела (КУ)

08.5.0 - исследования и разработки в области досуга, культуры и религии (КУ)

08.6.0 - досуг, культура и религия, не классифицированные в других рубриках (КУ).

б) КИПЦ-ДХ определяет культуру с помощью следующих категорий:

13 - расходы на индивидуальное потребление некоммерческих организаций, обслуживающих домашние хозяйства (NPISHs):

13.3 - развлечения и культура

14 - расходы на индивидуальное потребление центрального правительства: 14.3 - развлечения и культура.

в) Категории КЦНО, относящиеся к культуре:

03 - развлечения и культура

03.1 - услуги в области развлечений и спорта

03.2 - услуги в области культуры

1 Классификации и таблицы соответствия можно получить в реестре классификаций СОООН и на европейском сайте RAMON. 
Следует отметить, что оценка культуры лишь с помощью указанных выше категорий или данных СНC привела бы к недооценке вклада культуры в экономику. Это одна из причин того, почему некоторые страны, такие как Чили и Колумбия, начали развивать сателлитные отчеты по культуре. Например, Соглашение Андреса Бельо (САБ) международная межправительственная организация, работающая в Колумбии и нескольких других латиноамериканских странах, в настоящее время развивает методологию применения сателлитного отчета по культуре. Сателлитный отчет поможет оценить экономический вклад культурных отраслей и деятельности в ВВП. Такой подход составляет особую проблему при оценке и учете нерыночных продуктов и деятельности в области культуры. ССК может служить в качестве интеграционной модели для развития национальных сателлитных отчетов путем поощрения использования конкретных классификаций, в частности, МСОК и МСКЗ. Преимущество такого подхода состоит в том, что он позволяет проводить более четкую финансовую оценку культуры с помощью бухгалтерских методологий. С другой стороны, данная система отличается более широким подходом к измерению культурной деятельности и ее воздействию, чем сателлитные отчеты, сосредоточенные лишь на экономическом воздействии.

\section{2 Определение культурной производственной деятельности и продуктов культуры: применение Классификации основных продуктов (КОП) и Международной стандартной отраслевой классификации (МСОК)}

В этом разделе показано, как использовать КОП 2 и МСОК 4 для определения производственной культурной деятельности. Он охватывает в основном четыре первые фазы производственного цикла: создание, производство, распространение и демонстрацию/восприятие/передачу.

Фаза потребление/участие связана с экономическим и социальным поведением, отражаемым разными статистическими инструментами, рассматриваемыми в Разделе 4. Например, товары культуры могут производиться на некоммерческой основе некоторыми производителями, в число которых входят государственные организации, добровольные общества, любители или специальные группы артистов и создателей.

Несмотря на то, что КОП пока используется недостаточно широко, более высокий уровень детализации может позволить увязать ее с МСОК, что приведет к повышению сопоставимости и более точному выявлению производственных отраслей и продуктов культуры (см. Раздел 5, Таблицу 2). Это имеет особое значение в случае данных об услугах. Главная задача КОП состоит в предоставлении системы международной сопоставимости статистических данных, связанных с продуктами и служащих ориентиром для развития или пересмотра существующих схем классификации продуктов с тем, чтобы сделать их сопоставимыми с международными стандартами. МСОК создана для повышения совместимости классификации продуктов. В принципе, КОП распределяет товары или услуги по категориям, которые обычно производятся в рамках одной отрасли, как они определяются в МСОК.

МСОК предназначена стать стандартной классификацией производственной деятельности. Ее главная цель состоит в предоставлении комплекса типов деятельности, который может быть использован для сбора и представления статистических данных в соответствии с этими видами деятельности. Поэтому МСОК стремится представить этот комплекс типов деятельности таким способом, чтобы их можно было классифицировать в соответствии с экономической деятельностью, которую они воплощают. Она представляет собой согласованную и последовательную классификационную структуру экономической деятельности, основанную на ряде разделяемых в международном плане понятий, определений, принципов и правил классификации,. МСОК составляет 
комплексную систему, в рамках которой можно собирать и сообщать экономические данные в формате, предназначенном для целей экономического анализа, принятия политических решений и выработки политики (UNSD, 2008).

В целом, МСОК охватывает производственную деятельность, т.е. экономическую деятельность в рамках производственных границ Системы национальных счетов. Производственная деятельность определяется как использование вложений для производства продукции. Одним из главных преимуществ применения МСОК является то, что в отличие от КОП она широко используется странами. Однако МСОК, имеющая лишь четырехзначные коды, менее детализирована, чем КОП; соответственно, некоторые виды культурной деятельности нередко скрыты в более общих категориях или сгруппированы под одним кодом. Вот почему в Таблице 2 отражено соответствие между двумя классификациями. Оно связывает производственную деятельность с произведенным продуктом для выявления той части пограничной отрасли, которая относится к производственной деятельности в области культуры.

\section{Ограничения при использовании КОП и МСОК}

Хотя, как упоминалось выше, эти классификации не были созданы специально для культуры, их можно использовать для начального рассмотрения культурной деятельности и продуктов.

\section{коП}

Как отмечается в Таблице 2, КОП лучше приспособлена к классификации новых фрорм культуры, таких как цифровые средства, включая загружаемые музыку и электронные книги. Тем не менее, при использовании КОП (или любых других существующих международных систем классификации) некоторые блага и услуги культурного характера не могут быть определены. В частности, в КОП труднее дать определение деятельности, связанной с образованием и подготовкой кадров, которые лучше поддаются определению при использовании МСОК, версии 4 (а именно, 8541 и 8542, соответственно охватывающие Образование в области спорта и досуга и Образование в области культуры), МСКЗ 08 и собственно Международной стандартной классификации образования (МСКО) ЮНЕСКО (UNESCO-UIS, 2006d).

Это те случаи, когда категории КОП включают как деятельность в области культуры, так и за ее рамками, которую нельзя разделить. В большинстве случаев эти разделы КОП включены для использования в ССК. Тем не менее, это может привести к переоценке измеряемой культурной деятельности. При возможности по каждой соответствующей категории пользователям данных рекомендуется отделять деятельность в области культуры от других ее видов.

\section{MCOK}

Версия 4 МСОК содержит категорию информации и коммуникаций (см. Таблицу 2), разработанную для отражения современного состояния этой отрасли. Хотя в этой версии улучшен охват деятельности в области вещания и кинематографии, но пока она не позволяет определить культурную деятельность, требующую использования Интернета, в частности, загрузки электронных книг и музыки.

МСОК не делает различий между фрормальным и неформальным производством, легальной и нелегальной продукцией, а также рыночной и внерыночной деятельностью, которая нередко принимает форму внерыночных услуг. МСОК предлагает 
альтернативную группировку для анализа и отчетности по неформальному сектору статистики, предназначенную лишь в качестве инструмента для стандартного способа представления данных по деятельности неформального сектора (UN, 2008).

Кроме того, будучи промышленной классификацией, МСОК не приспособлена для измерения непромышленной культурной деятельности. При использовании МСОК для измерении культурной деятельности существует один серьезный недостаток:

В разделе кустарные промыслы не проводится различия между современными и традиционными методами производства, что позволило бы определить произведенную вручную или традиционную продукцию.

Во всех областях культуры применяются следующие две категории МСОК:

і) 9000 (Творческие искусства и развлечения): эта категория охватывает широкий спектр творческой деятельности, связанной со всеми областями классификации (от А до Е) ССК. Если авторский кооператив или писательский кружок не может рассматриваться в качестве категории 581x Издательское дело, аналогичный подход может определять деловое предприятие или кооператив художников, струнный квартет или большую рокгруппу, которые в качестве коммерческого предприятия могут получать крупные доходы.

ii) 8542 (Культурное образование): эта категория включает формальное и неформальное образование в области культурной деятельности, в частности, в изобразительных искусствах, архитектуре, музыке и танцах. Поэтому его нельзя разместить в рамках какой-то отдельной области. Его можно рассматривать в качестве образования, свойственного каждой отрасли, или как предприятия и учреждения, использующие образование для развития культурной деятельности в каждой из соответствующих областей.

Еще одна категория МСОК, предлагаемая для использования, - 3220 (Музыкальные инструменты), она охватывает производство музыкальных инструментов. При использовании концепции культурного цикла производство музыкальных инструментов рассматривается в качестве культурной деятельности, поскольку оно является частью производственной составляющей (вклада) в артистическое самовыражение.

\section{3 Международная торговля культурными товарами и услугами: применение Гармонизированной системы (ГЗ) и EBOPS}

В этом разделе рассматривается международная торговля культурными благами и услугами. Данные по потокам товаров культуры собираются при использовании версии 7 Гармонизированной системы описания (ГС) и кодирования товаров (см. Таблицу 3) на основе таможенной статистики, разработанной Всемирной таможенной организацией, а данные по культурным услугам собираются при использовании системы Расширенной классификации услуг в платежном балансе (EBOPS). При использовании этих двух систем классификации можно определить уровень культурных потоков в рамках соответствующей экономической системы.

\section{Международные потоки товаров культуры}

В Гармонизированной системе товары классифицируются по их очевидным фризическим характеристикам, а не в соответствии со статусом национального содержания, культурной ценностью или иными аналогичными критериями. Она отражает лишь декларируемые физические товары при пересечении ими границ. Поэтому чтобы иметь более полную картину культурных потоков, важно сопоставлять данные о товарах с данными об услугах. 
Список категорий, связанных с международными потоками, представлен в Таблице 3 Раздела 5. Категории ГС связаны с категориями версии 4 Стандартной классификации международной торговли (СКМТ 4), уровень детализации которой невелик, но она широко используется в таможенной статистике во многих странах.

Тем не менее, используя данные таможни, измерить некоторые области культуры достаточно сложно. В частности, используя категории ГС, нельзя провести различия между промышленными и кустарными художественными промыслами. Для них применяются лишь следующие категории:

$\begin{array}{ll}5007 & \text { шелковый трикотаж или шелковые отходы } \\ 5111-5113 & \text { шерстяной трикотаж или животный волос } \\ 5208-5212 & \text { хлопчатобумажные ткани } \\ 5309-5311 & \text { тканый материал для бумажного шпагата } \\ 57 & \text { ковры и другие тканые покрытия для пола } \\ 60 & \text { вязанные спицами или крючком ткани. }\end{array}$

Особое внимание следует уделять данным о кино, где заявленная на таможне оценка часто делается по копии и не включает цену авторских прав. Поэтому эти данные следует дополнять данными потоков интеллектуальной собственности, которые можно получить по данным услуг, собранным в агентствах по авторским правам.

\section{Международные потоки культурных услуг}

Данные по культурной торговле и услугам следует собирать в соответствии с последней классификацией, предоставляемой EBOPS на основе 6 версии Платежного баланса (BPM6) (IMF, 2008), также использующей КОП 2 для группировки различных услуг. Классификация EBOPS должна измениться в ходе процесса пересмотра Пособия по статистике международной торговли услугами (UN, 2002), работа над которым будет завершена в 2010 г.

Платежный баланс операций по услугам главным образом связан с предложением услуг за рубежом, когда поставщик и потребитель остаются в своих странах, а границы пересекают услуги.

Как и в других международных классификациях, культура в EBOPS не выделена в особую категорию. Культурные услуги представлены в ней как дополнительные, а не нормативные, $и$ не собираются систематически. Предложенные изменения к классификации в 2010 г. позволят лучше измерять культурные услуги. Таблица 1 основана на проекте пересмотренных категорий, разработанном в июне 2009 г.

Большая часть данных по туризму как культурным услугам помещена в разделе Путешествия, который относится только к зарубежным туристам. Доходы от путешествий связаны с товарами и услугами, приобретенными путешественниками для собственного употребления или выбывающими из экономической системы как приобретенные нерезидентами во время пребывания в данной стране. Расходы от путешествий определяются как товары и услуги, приобретенные путешественниками для собственного употребления или выбывающими из другой экономической системы как приобретенные резидентами во время пребывания в другой стране. B EBOPS путешествия разделены на деловые и личные. Большая часть культурного туризма, регистрируемого в категории Личные путешествия, «охватывает товары и услуги, приобретенные лицами, выезжающими за границу с иными целями, чем деловые, такими как проведение отпуска, участие в оздоровительных и культурных мероприятиях, посещения друзей $и$ родственников, а также паломничество» (IMF, 2008). 
Таблица 1. Культурные услуги, определяемые категориями EBOPS

\begin{tabular}{|c|c|c|}
\hline ПБ6 & EBOPS & Обозначения \\
\hline \multicolumn{3}{|c|}{ Основные культурные услуги } \\
\hline 1.A.b.8. & $\begin{array}{l}8.4 .1 \\
8.4 .2\end{array}$ & $\begin{array}{l}\text { Лицензии на воспроизводство и/или распространение аудиовизуальных } \\
\text { продуктов } \\
\text { Лицензии на воспроизводство и/или распространение сопутствующих } \\
\text { продуктов } 1\end{array}$ \\
\hline 1.A.b.9.3. & 9.3 .1 & Услуги информационных агентств² \\
\hline 1.A.b.9.3. & 9.3 .2 & Другие информационные услуги ${ }^{3}$ \\
\hline 1.A.b.10.2. & 10.2 .2 & $\begin{array}{l}\text { Реклама, изучение рыночной конъюнктуры и опросы общественного } \\
\text { мнения }\end{array}$ \\
\hline 1.A.b.10.3. & 10.3.1.1 & Услуги в области архитектуры \\
\hline 1.A.b.11.1. & 11.1.1 & Аудиовизуальные продукты \\
\hline 1.A.b.11.1. & 11.1.2 & Сопутствующие услуги ${ }^{4}$ \\
\hline 1.A.b.11.2. & 11.2 .3 & Наследие и восстановительные услуги ${ }^{5}$ \\
\hline \multicolumn{3}{|c|}{ Оборудование и сопутствующие материалы } \\
\hline 1.A.b. 8. & 8.3 & $\begin{array}{l}\text { Лицензии на воспроизводство и/или распространение компьютерного } \\
\text { программного обеспечения }\end{array}$ \\
\hline 1.A.b.9.2 & 9.2 .1 & Компьютерные услуги \\
\hline 1.A.b.9.2 & 9.2 .2 & Другие компьютерные услуги \\
\hline \multicolumn{3}{|c|}{ Сопутствующие культурные услуги ${ }^{6}$} \\
\hline \multicolumn{3}{|l|}{ Туризм } \\
\hline 1.A.b.4.2.3 & 4.2.3. & Путешествия - Другие частные \\
\hline
\end{tabular}

Примечания:

В эту категорию также включены другие художественные и литературные лицензии, в частности, артистов, авторов, композиторов, скульпторов и других, в том числе художников-декораторов, художников по костюмам и художников по свету.

2 Информационные агентства предоставляют средствам массовой информации новости, фотографии и статьи по актуальным вопросам.

Включая услуги библиотек и архивов.

Включая другие культурные услуги.

Восстановительные услуги включены в категорию 11.2.3 - Наследие и восстановительные услуги.

В эту категорию следует включать все расходы на культуру, сделанные за границей при любом типе путешествий (обучение, деловые поездки или лечение).

\section{4 Занятость в области культуры: применение Международной стандартной классификации занятий (МСКЗ)}

Этот раздел посвящен создателям, производителям и распространителям, вовлеченным в создание или производство объектов культурной деятельности индивидуально, в группах или организациях. Их можно распределить по категориям данных занятости, используя классификацию МСКЗ.

Следующие определения занятости в сфере культуры в основном основаны на определениях Австралийской и новозеландской стандартной классификации занятости (AHCК3) (ABS and Statistics New Zealand, 2009) и Канадской системы статистики культуры (Statistics Canada, 2004a). Хотя охват австралийских и новозеландских определений шире, определения, предлагаемые ССК, сосредоточены исключительно на показателях занятости в области культуры, связанных с творчеством и искусством в рамках основных областей, представленных на Схеме 2. 
Основные культурные профессии включают профессии, связанные с творческим и художественным производством, собиранием и хранением культурного наследия. Эти профессии включают задачи и обязанности, направленные на:

- Создание, развитие, сохранение или отражение культурного или символического и духовного значения;

- Создание, производство и распространение культурных благ и услуг, которые обычно закреплены правами интеллектуальной собственности; и

- Достижение целей художественного творчества (например, визуального, музыкального, литературного, балетного или драматического искусства).

Более широкое определение, охватывающее дополнительные области, указанные на Схеме 2, обычно относятся к досугу, в частности, спорту и путешествиям. Эти области включают виды деятельности, связанные со спортом или активным отдыхом, доставляющим удовольствие, расслабление, развлечение или восстановление сил.

\section{Измерение занятости в сфере культуры}

При определении занятости в сфере культуры необходимо включать как профессии по отраслям культуры, так и относящиеся к культуре профессии в отраслях, не связанных с культурой, таких как дизайн (см. Схему 3).

На Схеме 3 культурный сектор отражен так, как он рассматривается в системе (на оранжевом поле), указывая различные группы культурных профессий - как формальные, так и неформальные. Не относящиеся к культуре отрасли следует включать в схему только при оценке культурной занятости, если они включают работников культуры. Примером культурной профессии человека, работающего в области, не связанной с культурой, может служить профессия дизайнера в автомобильной промышленности.

\section{Схема 3. Занятость в сфрере культуры}




Вклад кустарных отраслей ${ }^{2}$ в занятость в сорере культуры достаточно велик. В развивающихся странах связанные с культурой профессии часто рассматриваются как дополнительные, поскольку сельскохозяйственные и другие рабочие могут иметь дополнительную ремесленную специальность. Эта информация нередко не указывается и не отражается в переписях населения и обследованиях рабочей силы. Такие скрытые или «вкрапленные» культурные профессии могут не включать большое число специалистов, которое нельзя точно определить при проведении выборочных опросов. Во многих случаях они включают самостоятельных или внештатных работников небольших компаний с числом занятых менее десяти человек, которые нередко остаются неохваченными в опросах хозяйственной деятельности. Часто считается, что доля работы культурного или творческого характера особенно высоко представлена на небольших предприятиях, и в этом плане даже европейская статистика может значительно недооценивать занятость в области культуры.

Кроме того, в занятости в сорере культуры большую роль нередко играют волонтеры и неоплачиваемая деятельность. Для более полной оценки такого рода деятельности необходимы дополнительные методологические исследования.

Чтобы определить культурные профессии в отраслях, не связанных с культурой (см. Схему 3), важно сочетать применение данных при использовании категорий МСКЗ с данными о промышленности на основе категорий МСОК для получения более точных показателей общей занятости в области культуры по странам (Cunningham and Higgs, 2008).

\section{Определение культурных профессий в соответствии с МСКЗ 08}

Классификация МСКЗ основана на двух понятиях: работе и опыте. Работа в соответствии с МСКЗ 08 определяется как «комплекс задач и обязанностей, выполняемых или предназначенных к исполнению одним человеком для конкретного работодателя, включая самостоятельную деятельность». Опыт определяется как «способность выполнять задачи и обязанности, связанные с определенной работой» (ILO, 2008).

Выделить все виды профессий в отдельную категорию не представляется возможным, поскольку они охватывают многие разнообразные типы профессий, требующих самого разного опыта. Тем не менее, МСКЗ 08 включает новые категории профессий в области культуры, вводимые на основе совместного предложения, выдвинутого в 2007 г. Международной организацией труда (МОТ), Организацией экономического сотрудничества и развития (ОЭСР) и ИСЮ, которое позволит уточнить положение с профессиями в области культуры.

В МСКЗ 08 и Системе статистики культуры ЮНЕСКО 2009 использованы следующие категории основных профессий в области культуры:

262 библиотекари, архивариусы и хранители

264 авторы, журналисты и лингвисты (новая категория)

265 деятели культуры и актеры

343 художественные помощники деятелей культуры

3521 специалисты в области вещания, аудио- и видеозаписи

73 мастера кустарных промыслов и печати (новая категория, в которую включаются все мастера кустарных промыслов, работающие с глиной, металлом, стеклом, деревом, тканями и т.д.).

2 Отрасль производства, где создание продуктов и услуг связано, скорее, с домашним, чем с фрабричным производством. 
В Таблице 4 Раздела 5 предложен перечень категорий, которые могут служить основой для определения профессий в области культуры. Тем не менее, при оценке занятости в области культуры остаются некоторые нерешенные проблемы. Культурные профессии находятся во всех категориях МСКЗ, и классификация их иногда недостаточно детальна для того, чтобы провести между ними четкие различия. Кроме того, профессии могут не включать большое число специалистов, чтобы выделить в МСКЗ отдельную категорию. Например, трудно различать культурные профессии в рамках следующих основных категорий:

\section{Наследие и хранение}

Профрессии, связанные с наследием и хранением, такие как археологи или хранители, в МСКЗ не имеют определения. Они включены в категорию 2632 (социологи, антропологи и схожие с ними профессионалы). Специалисты, работающие в этой области, обычно обладают научными знаниями и высоким уровнем опыта, который может соответствовать Основной группе 2 профессионалов в МСКЗ.

Управляющие, руководители и законодатели

Что касается управляющих, руководителей и законодателей, с профессиями в области культуры связана лишь категория 1113 МСКЗ (традиционные вожди и старейшины селений). Тем не менее, следует рассмотреть вопрос о том, куда отнести такие профессии, как руководитель художественной компании. В частности, отсутствует категория для управляющих и чиновников в сфрере искусства.

\section{Образование}

Преподаватели в области культуры отнесены к разделу «Другие учителя» в таких категориях, как 2354 (другие учителя музыки), 2355 (другие учителя искусств) и 2353 (другие учителя языков) ${ }^{3}$. Однако, в целом преподаватели искусств и гуманитарных предметов всех уровней образования (высшее, профессиональное и среднее) не включены в эту категорию, поскольку их можно отнести к категории формального, неформального и профрессионального образования.

\section{Информационно-коммуникационные технологии (ИКТ)}

Культурные профессии, имеющие отношение к ИКТ, в основном связаны с аудиовизуальными профессиями и новыми средствами, в частности, к ним можно отнести разработчика мультимедиа. Они распределены по двум областям: Аудиовизуальные и интерактивные средства и Дизайн и творческие услуги. Однако, в МСКЗ 08 отсутствует специальная категория для менеджеров по вещанию и мультимедиа, включая специалистов по компьютерной графике.

\section{5 Измерение культурного наследия}

Как отмечалось ранее, область культурного наследия характеризуется моделью, отличной от других. Большая часть деятельности в этой области связана с сохранением и сбережением. В этом плане с экономической точки зрения культурное наследие является

3 В некоторых странах, в частности, в Австралии, преподаватели языков не включены в число культурных профессий. 
активом. Ценность активов может повышаться или понижаться в зависимости от того, в каком они поддерживаются состоянии. В экономических исследованиях был дан анализ экономической ценности культурного наследия в соответствии с общественными предпочтениями (Navrud and Ready, 2002). Там была подсчитана стоимость его использования на основе цены, которую кто-то согласен платить за сохранение культурного наследия или посещение его объектов. В этих подсчетах также учли неиспользованную ценность культурного наследия, поставив вопрос о том, сколько кто-то готов платить за сохранение этого наследия для будущих поколений. Однако, следует подчеркнуть, что такую условную стоимость или определение затрат на путешествия трудно сгруппировать в провинциальные или региональные ценности за счет эффееков замещения (Hoehn and Randall, 1989).

Помимо того, что культурное наследие - это экономическая ценность, оно является и общественным благом. Оно включает эстетические, исторические, социальные, духовные и образовательные ценности. Территории материального культурного наследия часто используются для празднеств, в ходе которых даются представления, содержащие элементы нематериального культурного наследия. В развитых странах посещение таких культурных ценностей, как памятники и музеи, нередко фриксируются. Однако, отличие данных о культурном туризме от статистики обычного туризма требует дальнейшей разработки. Выборочные опросы как туристов, так и местных жителей в районах культурного наследия являются важным статистическим инструментом. В развивающихся странах опросы посетителей таких территорий могут быть особенно важны, играя большую роль в системе статистики культуры, хотя там могут возникнуть такие проблемы, как сложность в проведении различий между участниками и зрителями.

\section{Роль авторских прав}

Авторские права применяются ко всей продукции в литературной, научной и художественной областях, независимо от фрормы еe выражения (WIPO, 1979). Литературные и художественные работы включают книги и другие произведения, музыку, пьесы, балет, фотографию, фрильмы, архитектурные чертежи, гравюры и литографии, картины и скульптуры (WIPO, 1979). ЮНЕСКО рассматривает авторские права и аналогичную правовую защиту в качестве основного условия для «повышения индивидуального творчества, развития культурных отраслей и поощрения культурного разнообразия» (UNESCO, 2009a).

Определение товаров и услуг, создающих права интеллектуальной собственности, является основной составляющей вклада культуры в экономику и имеет дополнительное преимущество, будучи связано с определенной системой законодательства. В ССК культурные блага и услуги определяются как потенциальные субъекты авторских прав. Авторские права применяются к большинству элементов каждой области.

Всемирная организация интеллектуальной собственности (ВОИС) разработала принципы для определения вклада института авторских прав в экономику (WIPO, 2003). Определение «основные отрасли авторских прав» аналогично определению культурных областей в ССК, однако здесь имеются некоторые исключения. В отличие от ВОИС, включающей авторские права в основные права по отраслям, в ССК такое положение отсутствует. Кроме того, определение культурной отрасли ВОИС отличается от используемого в настоящей системе, поскольку оно не охватывает области, в которых авторские права не применяются, такие как культурная практика или музейная деятельность. 


\section{4. Статистика культуры: измерение социальных параметров}

\section{1 Измерение участия в культурной деятельности}

В предыдущем разделе рассматривалось использование для сбора данных по статистике культуры таких международных систем классификации, как МСОК, МСКЗ и ГС. Данный раздел посвящен измерению социальных параметров культуры, являющихся основным компонентом культуры и ССК.

Главная проблема заключается в том, как оценивать социальные параметры культуры, часто имеющие место в неформальных отраслях при отсутствии экономических операций. Некоторые аспекты социальных параметров культуры связаны с ее символическими ценностями и той ролью, которую она играет в обретении ощущения самобытности, разделяемых ценностей и общности, предотвращающих отторжение от общества и способствующих достижению социальной сплоченности и стабильности. Они также связаны с нетоварным измерением культуры - практике, имеющей место в основном в рамках общин, не связанной с экономическими отношениями. Социальный аспект культуры не всегда легко поддается измерению. Тем не менее, существуют определенные общепринятые статистические стандарты, которыми можно пользоваться при изучении социальных параметров культуры.

Основными источниками данных об участии в культурной жизни являются опросы по домашним хозяйствам и затраченному времени. Тем не менее, такие обзоры требуют больших затрат, причем страны включают в разработанные для этих целей опросники совсем немного вопросов, связанных с культурой. Создание сопоставимых в международном плане и согласованных показателей по социальным аспектам культуры требует дальнейшего развития как в плане определений, так и стандартных инструментов. В связи с этим в настоящей системе сделана попытка прийти к широкому согласию по вопросу общего осмысления социальной модели культуры и дать общее направление дальнейшему развитию статистики, необходимое для определения социальных параметров культуры и соответствующих показателей и определений.

\section{Участие в культурной деятельности}

ССК включает все элементы участия в культурной деятельности или практике, будь то формальная занятость или посещение формальных (например, театральных представлений с оплаченными билетами) или неформальных культурных событий (общинных или семейных), независимо от финансовой стороны вопроса, или домашней культурной деятельности.

Экономическое измерение культурного участия можно отразить через данные статистических инструментов, выявляющих потребительские расходы на блага и услуги в области культуры и участие в платной культурной деятельности. Эти показатели обычно измеряются на основе расходов домашних хозяйств или обследований экономической деятельности, хотя в этом плане могут быть полезны и административные данные.

Термин «потребление» обычно используется, когда речь идет о деятельности, при которой потребитель за что-то платит, в то время как термин «участие» применяется, когда имеется в виду участие в любительских или неоплачиваемых мероприятиях. На практике провести здесь различия достаточно сложно, поскольку потребители/участники могут принимать участие в неформальной деятельности, расплачиваясь натурой или внося плату иными способами. Например, «потребитель» может оплатить услуги артиста, предоставив еду или кров артисту в обмен на представление, организовав, таким 
образом, обмен услугами. Равным образом, любители или неформальные артисты могут «стать профессионалами», завершив обучение или подготовку. Таким образом, общественная или неформальная культурная деятельность может вносить свой вклад во многие отрасли культуры.

Разовые обзоры культурного участия проводились в основном в Европейском Союзе (EC). Экспертная группа руководства EC по статистике культуры (LEG Eurostat, 2000) попыталась разработать региональную модель, применявшуюся в серии обзоров «Евробарометр». С тех пор в качестве эксперимента по применению этой модели были проведены три обзора для сбора согласованных данных по участию европейцев в культурной деятельности. В полезном определении европейской концепции участия в культурных процессах, данном Беннеттом, участие в культурной жизни включает искусства, а также повседневную деятельность, связанную с развлечениями. Оно касается «этнических отличий в культурных вкусах, ценностей и поведения, выражающихся не только в художественных предпочтениях и средствах, но также воплощенных в повседневном ритме различных жизненных укладов и способах, которыми они связаны с другими значимыми социальными характеристиками, такими, как класс и пол» (Bennett, 2001).

Таким образом, участие в культурных процессах связано с культурными обычаями, включающими потребление и деятельность в обществе, которые отражают качество жизни, традиции и верования. Оно распространяется на посещение формальных и платных мероприятий, например, в кинотеатрах или концертных залах, и неформальные культурные действия, такие, как культурные мероприятия сообществ или участие в любительских программах, а также повседневные действия, такие, как чтение книг. Участие в культурной жизни обычно измеряется в контексте сообщества, социальной группы, этнической принадлежности, возраста и пола. Анализ, основанный на принадлежности к этнической или социальной группе и полу, также может быть связан с измерением разнообразия культурного творчества в разных видах культурной деятельности.

Более того, участие в культурных процессах связано как с активным, так и с пассивным поведением. Оно распространяется на людей, присутствующих на концерте, и любителей, занимающихся музыкой. Целью опросов по культурному участию должна быть оценка всех его уровней, несмотря на сложности, связанные с различиями пассивного и активного поведения. Например, на некоторых фестивалях люди бывают одновременно и исполнителями (активными, творческими, воодушевляющими других), и зрителями (пассивными или стремящимися обрести вдохновение). Участие в культурной жизни не имеет отношения к деятельности, обусловленной должностными обязанностями, но связано с профессиями (ILO, 1988); например, оно охватывает посетителей музея, но не относится к экскурсоводу.

В 2006 г. в ИСЮ был подготовлен доклад о применении модели ЕС («Евробарометр») к условиям культурной деятельности в развивающихся странах. В докладе (UNESCO-UIS, 2006b) дается определение культурной деятельности по трем категориям:

i) В домашних условиях: (culture d'appartement) количество часов просмотра телевизионных программ, прослушивания радиопередач, прослушивания и просмотра музыкальных и видеозаписей, чтения и пользования компьютером и Интернетом.

ii) Вне дома: (culture de sortie) посещение кино, театров, концертов, музеев, памятников и достопримечательных мест. 
iii) Упрочение самобытности: (culture identitaire) относится к художественной самодеятельности, членству в культурных ассоциациях, массовой, этнической, общинной и молодежной культуре.

\section{Измерение культурной деятельности в домашних условиях}

Распространенным инструментом для измерения культурной деятельности в домашних условиях служит опрос учета затраченного времени. Для ее измерения вне дома и при упрочении самобытности подходят выборочные опросы.

В качестве части своей работы по «Улучшению измерения оплачиваемой и неоплачиваемой работы» Статистический отдел Организации Объединенных Наций $(\mathrm{COOOH})$ разработал проект «Международная классификация деятельности по статистике используемого времени» (ICATUS) (UN, 2005). Эта классификация предназначена для применения как в развитых, так и в развивающихся странах для статистического учета затраченного времени. ICATUS является единственной классификацией, предлагающей исчерпывающий перечень культурных обычаев, включая общинные обычаи. Список категорий помещен в Таблице 5 Раздела 5.

Обычаи, практикуемые в домашних условиях, описаны ниже с использованием категорий, определенных в контексте переменных, включающих «расположение», «способ путешествия», «к кому» и «с кем».

Структура ICATUS распределяет по категориям деятельность, в которой люди заняты в соответствии с классификацией $\mathrm{CHC}$, по двум большим группам, связанным с институциональными структурными единицами, производящими продукцию деятельность, осуществляемую отдельными лицами в качестве членов домашних хозяйств, которая является вкладом в продукцию домашних хозяйств, и деятельность, осуществляемую отдельными лицами, которая является вкладом в продукцию структурных подразделений, не относящихся к категории домашних хозяйств (UNSD, 1998).

Частое проведение обследований участия в культурной жизни требует больших ресурсов. В настоящей системе предлагается сосредотачивать обзоры участия на общих уровнях участия и регистрации той области, в которой имеет место данная культурная деятельность. Систематическое использование таких обследований - например, обследований участия в таких областях, как музыка, танцы и чтение - позволит рассматривать социальные проблемы, а также соединит любительскую или неформальную культурную продукцию с более формальной деятельностью. Такая связь имеет жизненно важное значение при рассмотрении основного вопроса, связанного с коммерциализацией отрасли культуры и ее воздействием на общество в целом.

\section{2 Измерение нематериального культурного наследия (НКН)}

В этом разделе рассматриваются исходные элементы и подходы к измерению нематериального культурного наследия (HКН). Для выработки верной политики по развитию и приспособлению к потребностям отдельных сообществ здесь нужны специальные измерительные инструменты.

В настоящей статистической системе НКН понимается как «обычаи, изображения, произведения, знания и опыт - а также инструменты, предметы, памятники материальной культуры и связанные с ними культурные пространства-которые признаются сообществами, группами, а в некоторых случаях отдельными лицами в качестве части своего культурного наследия» (UNESCO, 2003b, ст. 2). Поэтому НКН может проявляться в любой области культуры и в качестве такового в системе оно представлено как сквозная область. 


\section{Рамка 1. Принципы европейских опросов по учету использованного времени}

В число основных методологических предпосылок входят:

- Опрос должен охватывать население в целом, а не сосредотачиваться на какой-то его части. В идеале он должен охватывать лиц старше 10 лет. Если это невозможно, должны быть представлены лица старше 15 лет.

- Объем выборки должен быть достаточным, чтобы обеспечить представительность результатов для всех оценок и таких демографических переменных, как возраст, пол или уровень образования.

- В журнал опроса следует включить два дня: один рабочий и один выходной.

- Опрос по учету использованного времени (TUS) должен охватывать 12 последовательных месяцев. Если это невозможно, он может охватывать рабочие дни недели.

- В журнале следует использовать короткие временные интервалы по 10-15 минут.

- В опрос должна входить основная и дополнительная деятельность. Это особенно важно для отражения привычек, связанных со средствами массовой информации, такими, как прослушивание радио во время вождения машины или просмотр телевидения во время мытья посуды.

- Респондентам следует использовать обширный список категорий деятельности, особенно в отношении пользования средствами массовой информации.

Хотя TUS представляет собой наиболее точный способ измерения привычек, связанных со средствами массовой информации, этот инструмент очень дорог при использовании. Разумной альтернативой ему является включение вопросов об использованном времени в выборочном опросе населения в течение недели в рабочие и выходные дни. В этом случае следует использовать перечень видов деятельности с заранее обозначенными категориями.

Выборочные опросы населения можно также применять для измерения культурной деятельности вне дома и при упрочении самобытности, поскольку эти две категории связаны с менее распространенными и реже встречающимися обычаями. Кроме того, чтобы обеспечить международную сопоставимость, национальные обзоры должны соответствовать следующим методологическим критериям:

- Обычным базисным периодом является один год. Респонденты отчитываются о своем участии в культурной деятельности на протяжении последних 12 месяцев.

- Последняя единица выборки должна быть индивидуальной. Опросов по доверенности (часто используемых при обследованиях домашних хозяйств) следует избегать, поскольку респонденты зачастую не знают обо всех видах культурной деятельности, которыми занимаются другие члены семьи.

- При возможности для международной сопоставимости следует использовать опросы с более широким спектром вопросов, чем вопросы об участии в культурной деятельности, такие как общие социальные опросы или опросы, касающиеся досуга. Опросы, связанные с культурой, имеют тенденцию к завышению оценки участия в культурной деятельности. Тем не менее, если другие данные отсутствуют, результаты таких «целевых» опросов также можно использовать.

\section{Адаптация Принципов опросов по учету использованного времени к развивающимся странам}

- Социально-демографические характеристики: в идеале опрос должен включать лиц от 5 лет и старше, что в развивающихся странах является обычной практикой при сборе данных. Следует принимать в расчет такие демографические переменные, как возраст, пол или уровень образования, основную деятельность, уровень дохода и этническую принадлежность.

- Объем выборки: объем выборки следует планировать в соответствии с численностью и характеристиками населения для обеспечения его репрезентативного характера.

- Номенклатура и классификации: для обеспечения международной сопоставимости рекомендуется использовать международные классификации товаров и услуг.

- Рабочая группа: важно координировать работу среди различных общностей, вовлеченных в сферу культуры. Для составления надежного тематического опроса рекомендуется создать междисциплинарную рабочую группу, состоящую из статистиков, экономистов и специалистов в области методологии культуры.

4 Статистическое бюро Европейского Союза - Eвростат, опубликовало подробное изложение принципов в Скоординированных европейских опросах по учету использованного времени (HETUS). С ними также можно ознакомиться на сайте: http://epp.eurostat.ec.europa.eu/cache/ITY_OFFPUB/KS-CC-04-007/EN/KS-CC04-007-EN.PDF 
Некоторые продукты НКН чрезвычайно трудно поддаются количественному и качественному измерению, поскольку они нематериальны. Но из этого не следует, что каждое проявление НКН должно быть измерено.

Если НКН проявляется и передается через музыку, повествование, танца или иные фрормы исполнения, возможны и другие приемы. Например, опросы на соответствующем уровне (местном, региональном, национальном) помогли бы отразить численность участников/исполнителей. ${ }^{5}$ Обследования также могли бы отражать содержание документа и способ передачи.

Нематериальные аспекты культурного наследия представляют собой большую проблему для измерения, поэтому для разработки соответствующих инструментов измерения необходима дальнейшая методологическая работа.

\section{Языки}

Важной переменной для многих стран является язык. Языки представляют собой одно из средств выражения и передачи нематериального культурного наследия и способом восприятия и понимания окружающего мира, общественной и естественной среды обитания данной группы.

Вопрос о том, как определить и измерить язык и число говорящих на нем людей, оживленно дискутируется. Для определения языков лингвисты пользуются двумя критериями - 1) язык рассматривается как набор взаимно понятных речевых средств, и 2) групповая самоидентификация: если две группы людей рассматривают себя как разные народы, они должны говорить на двух разных языках (UNESCO-UIS, 2006c).

Во многих странах в переписи населения включены вопросы о языке. Как указывается в Принципах и рекомендациях ООН о переписях населения и домашних хозяйств (UN, 2007), обычно собираются три типа данных о языке:

а) Родной язык, определяемый как язык, на котором обычно говорили дома в раннем детстве человека;

б) Разговорный язык, определяемый как язык, на котором человек говорит в настоящее время или чаще всего в настоящее время говорит дома; $И$

в) Способность говорить на одном или более языках, называемых при переписи.

Данные о языке, в частности, позволяют определить положение и тенденции в области лингвистического разнообразия и численность людей, говорящих на туземных языках. В ЮHЕСКО (UNESCO, 2003c) разработана методология оценки жизненности языков и угрозы им на основе следующих девяти критериев:

○ абсолютное число говорящих на языке;

○ часть говорящих на языке по отношению ко всему населению;

○ доступность материалов для обучения языку и грамотности;

○ реакция на новые области и средства массовой информации;

○ тип и качество документов;

○ передача языка от поколения к поколению;

○ отношение членов сообщества к своему языку;

○ изменения в сорерах применения языка; и

5 В отдельных случаях на разных стадиях представления зрители и исполнители могут быть одними и теми же людьми. 
○ отношение и политика государственного и официального языка, включая официальный статус и использование.

ЮНЕСКО применяет эту методологию для составления списка языков, которым угрожает опасность, в Атласе языков мира, находящихся в опасности, чтобы отследить исчезновение форм нематериального культурного наследия и источников разнообразия (UNESCO, 2009b).

\section{Измерение практики упрочения самобытности}

Другим способом измерения социальных параметров культуры является взгляд на социально-экономическое воздействие мероприятий в области культуры.

В Колумбии оценивали экономическое, социальное и культурное воздействие «фиесты». «Фиесты» можно определить как «мифические символические структуры верований, мифов, концепций жизни и мира (космогония), коллективных представлений и связанных с ними этапов жизненного цикла в экономике, религиозных верованиях, политике и иных видах мотиваций. Они передаются через традиции и свойственны определенному обществу на определенном пространстве в определенное время» (Convenio Andres Bello, 2004). Социальное и культурное измерение фриесты можно проанализировать, рассмотрев:

- социальное участие: активное участие зрителей/актеров сообщества в организации фиесты;

- самобытность: свойственность события данному сообществу (культурная и социальная идентификация);

- Культурное разнообразие: наличие различных культурных составляющих (традиционной, этнической, религиозного опыта, художественного выражения, отдыха и развлечений) во время подготовки и проведения фииесты;

- Социальная сплоченность: участие различных секторов/акторов в подготовке и проведении фиесты; и

- Общественная принадлежность: индивидуальные и общественные формы, через которые группы и социальные акторы выражают право собственности на фриесту.

\section{Другие социальные параметры культуры}

При измерении вклада культуры в социально-экономическое развитие очень полезными могут быть концепции культурного капитала и социального капитала. Как отмечал Дэвид Тросби, «объект культурного капитала можно определить как достояние, воплощающее или являющееся источником культурной ценности дополнительно к любой экономической ценности, которой он может обладать... здание, отнесенное к культурному наследию, может иметь некоторую коммерческую ценность как объект недвижимости, однако его истинная ценность для отдельных лиц или сообщества, скорее всего, состоит в эстетических, духовных, символических или иных элементах, которые могут выходить за рамки или лежать за пределами экономических подсчетов. Эти ценности можно назвать культурной ценностью здания. Определяемый таким образом культурный капитал может существовать в материальной форме в качестве зданий, территорий расположения достопримечательностей, предметов искусства, памятников материальной культуры, или в нематериальной фрорме в форме идей, обычаев, верований и традиций» (Throsby, 2001). 


\section{Рамка 2. Знания коренных народов и традиционные знания}

Традиционные и местные знания нередко ассоциируются со знаниями коренных народов. Уганда описывает знания коренных народов как «традиционные и местные знания, существующие и получившие развитие в специфических условиях общин коренных народов в определенном географическом районе» (Uganda, 2006).

В соответствии с определением традиционных и местных знаний, данным Секретариатом тихоокеанского сообщества, «проявления культуры означают любой способ, которым выражаются традиционные знания, независимо от содержания, качества или цели, они могут иметь материальный или нематериальный характер и, не ограничиваясь вышесказанным, включают:

а) имена, рассказы, напевы, загадки, истории и песни в устном исполнении;

б) предметы искусства и кустарных промыслов, музыкальные инструменты, скульптуры, картины, резьбу, керамику, терракотовую мозаику, деревянные изделия, металлические изделия, рисунки, ювелирные изделия, плетение, вышивку, изделия из раковин, ковры, одежду и ткани;

в) музыку, танцы, театр, литературу, церемониалы, ритуальные представления и культурные обычаи;

г) очерченные формы, части и детали конструкций и визуальных композиций; и

д) архитектурные формы.

Священное-тайное означает любые традиционные знания или проявления культуры, имеющие тайное или священное значение в соответствии с законами и обычаями его традиционных обладателей.

Традиционные знания включают любые знания, которые обычно:

а) созданы, получены или внушены с традиционными экономическими, духовными, ритуальными, повествовательными, декоративными или развлекательными целями;

б) передаются из поколения в поколение;

в) рассматриваются как принадлежащие определенной традиционной группе, клану или сообществу людей в [данной стране]; и

г) коллективно созданы и поддерживаются.»

Источник: SPC, 2002.

В Перечне видов творчества Гонконга социальный капитал выражается «в плане доверия, взаимодействия, сотрудничества и обширных общественных связей... ведущих к повышению коллективного благосостояния, участия в общественной жизни и гражданской активности... создающих возможности для процветания личности и общества. Он измеряется по девяти показателям: всеобщее доверие, институциональное доверие, взаимодействие, ощущение эффрективности, сотрудничество, положительное отношение к меньшинствам, поддержка современных ценностей, самовыражение и участие в общественной жизни» (Centre for Cultural Policy Research, 2005).

Для включения в систему других областей культуры, в частности некоторых социальных элементов культуры и их воздействия на общество, необходимо продолжать работу, связанную с другими параметрами культуры. Отношение культуры и окружающей среды, частично включенное в область Культурное и природное наследие, требует дальнейшей разработки, особенно в плане устойчивого развития. Одним из наиболее остро обсуждающихся вопросов является отношение культуры и благосостояния, в частности, связь между культурой и здоровьем. Такие темы, как здравоохранение и окружающая среда в широком смысле выходят за рамки культуры, и здесь было бы уместно обсудить вопрос о связи между культурой и другими областями статистики. Например, такое обсуждение могло бы включить вопрос о потенциальном воздействии такого рода культурной деятельности, как игра на музыкальном инструменте, на общее состояние здоровья (Michalos, 2003 and 2005). 


\section{5. Сбор данных: таблицы международных категорий}

В настоящем разделе приводится перечень категорий по международным классификациям, упомянутым в предыдущем разделе. Каждый тип производственной деятельности, товаров, услуг, типов занятости или обычаев определяется в своей области культуры и по функции в рамках культурного цикла. Тем не менее, это не означает, что можно дать определение каждой области классификации или каждому этапу культурного цикла. Так, например, МСОК, КОП, ГС и EBOPS связаны с экономикой, эти категории в основном охватывают этапы от создания до презентации, в то время как ICATUS охватывает участие.

Каждая категория должна быть упомянута лишь единожды. В целях достижения соответствия между МСОК и КОП (Таблица 2) категории МСОК могут появляться в разных областях. Однако, при использовании категорий МСОК для оценки объема культурных отраслей их следует учитывать лишь единожды. Категории, выделенные курсивом и звездочкой следует учитывать лишь в том случае, если можно провести различие между культурной деятельностью и деятельностью, не относящейся к культуре. 
Таблица 2. Культурная производственная деятельность, товары и услуги в определениях категорий кОП 2 и МсоК 4

\begin{tabular}{|c|c|c|c|c|c|c|}
\hline \multicolumn{7}{|c|}{ ОБЛАСТИ КУЛЬТУРЫ } \\
\hline \multirow{2}{*}{ Область } & \multicolumn{3}{|r|}{ Производственная деятельность ${ }^{1}$} & \multicolumn{3}{|r|}{ Товары и услуги } \\
\hline & Мсок 4 & & Описание & коп 2 & & Описание \\
\hline \multirow{4}{*}{ 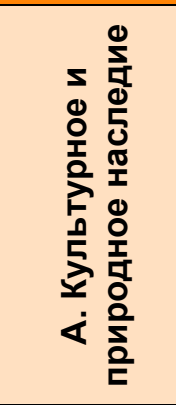 } & 9000 & & $\begin{array}{l}\text { Творческая деятельность, деятельность в области } \\
\text { искусства, развлечений и отдыха }\end{array}$ & 38962 & & $\begin{array}{l}\text { Почтовые или гербовые марки, гашеные марки, конверты } \\
\text { первого дня, почтовые принадлежности (гербовая бумага) и т.п.; } \\
\text { коллекции и коллекционные экземпляры, представляющие } \\
\text { зоологический, ботанический, минералогический, } \\
\text { анатомический, исторический, этнографический или } \\
\text { нумизматический интерес; антиквариат }\end{array}$ \\
\hline & 9102 & 4 & $\begin{array}{l}\text { Деятельность музеев и функционирование исторических } \\
\text { мест и зданий }\end{array}$ & $\begin{array}{l}96411 \\
96412\end{array}$ & & $\begin{array}{l}\text { Музейные услуги за исключением исторических территорий и } \\
\text { зданий } \\
\text { Услуги по сохранению исторических территорий и зданий }\end{array}$ \\
\hline & 9103 & & $\begin{array}{l}\text { Деятельность ботанических садов, зоопарков и } \\
\text { заповедников }\end{array}$ & $\begin{array}{l}96421 \\
96422\end{array}$ & & $\begin{array}{l}\text { Услуги ботанических садов и зоопарков } \\
\text { Услуги заповедников, включая диких животных и птиц }\end{array}$ \\
\hline & 4774 & 5 & Розничная торговля подержанными товарами & $621^{* \star}$ & 6 & Неспециализированные магазины розничных торговых услуг \\
\hline \multirow{3}{*}{ 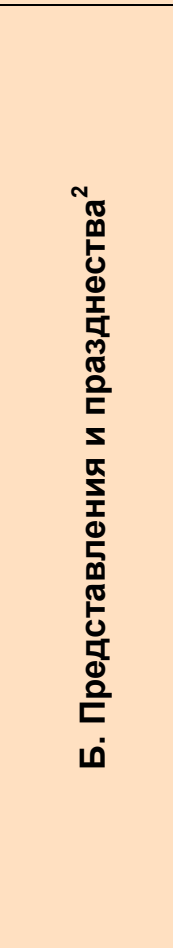 } & 9000 & 7 & $\begin{array}{l}\text { Творческая деятельность, деятельность в области } \\
\text { искусства, развлечений и отдыха }\end{array}$ & $\begin{array}{l}96210 \\
96220 \\
96230 \\
96290 \\
96310 \\
95997\end{array}$ & & $\begin{array}{l}\text { Услуги по продвижению и организации исполнительских искусств } \\
\text { Услуги по постановке и презентации исполнительских искусств } \\
\text { Услуги по оборудованию для исполнительских искусств } \\
\text { Другие услуги для исполнительских искусств и концертов } \\
\text { Услуги исполнительских искусств } \\
\text { Культурные и развлекательные ассоциации (отличные от спорта } \\
\text { или игр) }\end{array}$ \\
\hline & 3220 & & Производство музыкальных инструментов & $\begin{array}{l}38310 \\
38320 \\
38330 \\
38340 \\
38350 \\
38360\end{array}$ & & $\begin{array}{l}\text { Фортепиано и другие клавишные струнные музыкальные } \\
\text { инструменты } \\
\text { Другие струнные музыкальные инструменты } \\
\text { Духовые музыкальные инструменты (включая органы, } \\
\text { аккордеоны и медные духовые инструменты) } \\
\text { Музыкальные инструменты, звук которых извлекается или } \\
\text { усиливается с помощью электричества } \\
\text { Другие музыкальные инструменты (включая ударные } \\
\text { инструменты, музыкальные шкатулки и шарманки); манки; } \\
\text { свистки, рога и другие духовые сигнальные инструменты } \\
\text { Части и принадлежности музыкальных инструментов, } \\
\text { метрономы и камертоны }\end{array}$ \\
\hline & 5920 & & $\begin{array}{l}\text { Деятельность в сфере звукозаписи и издания } \\
\text { музыкальных произведений }\end{array}$ & $\begin{array}{l}32520 \\
47610 \\
96111 \\
96112 \\
96113 \\
84321 \\
73320\end{array}$ & 8 & $\begin{array}{l}\text { Печатные или рукописные нотные записи } \\
\text { Музыкальные диски, магнитофонные пленки или другие } \\
\text { носители } \\
\text { Услуги звукозаписи } \\
\text { Услуги по записи живой музыки } \\
\text { Оригиналы звукозаписи } \\
\text { Загрузка музыкальных аудио-программ } \\
\text { Услуги по лицензированию прав на использование } \\
\text { развлекательных, литературных и звуковых оригиналов }\end{array}$ \\
\hline
\end{tabular}




\begin{tabular}{|c|c|c|c|c|c|c|}
\hline & 4762 & & $\begin{array}{l}\text { Розничная торговля музыкальными и видеозаписями в } \\
\text { специализированных магазинах }\end{array}$ & 62242 & & $\begin{array}{l}\text { Услуги специализированных магазинов розничной торговли по } \\
\text { продаже радио- и телевизионного оборудования, аудио- и } \\
\text { видеозаписей, дисков и пленки }\end{array}$ \\
\hline \multirow{5}{*}{ 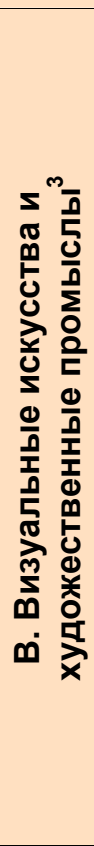 } & 9000 & 9 & $\begin{array}{l}\text { Творческая деятельность, деятельность в области } \\
\text { искусства, развлечений и отдыха }\end{array}$ & 38961 & & $\begin{array}{l}\text { Картины, рисунки и пастельные рисунки; оригинальные гравюры, } \\
\text { печатная графрика и литография; оригинальные скульптуры и } \\
\text { статуи из любых материалов }\end{array}$ \\
\hline & 7420 & 10 & Деятельность в области фотографии & $\begin{array}{l}83811 \\
83812 \\
83813 \\
83814 \\
83815 \\
83819 \\
83820 \\
38942 \\
38941\end{array}$ & & $\begin{array}{l}\text { Услуги по портретной фотографии } \\
\text { Реклама и сопутствующие услуги фотографиии } \\
\text { Услуги по фотографии в движении } \\
\text { Услуги по профессиональной фотографии } \\
\text { Услуги по реставрации и ретушированию фоотографий } \\
\text { Другие услуги, связанные с фотографией } \\
\text { Услуги по обработке фотографий } \\
\text { Экспонированные и проявленные фотографические пластины и } \\
\text { пленки, не имеющие отношения к кинематографии } \\
\text { Экспонированные, но не проявленне фотографрические } \\
\text { пластины, пленки, бумага, картон и ткани }\end{array}$ \\
\hline & 5819 & & Прочая издательская деятельность & 32540 & & Отпечатанные снимки, изображения и фотографии \\
\hline & 3211 & & Производство ювелирных и смежных товаров & $\begin{array}{l}38220 \\
38240 \\
38210 \\
\end{array}$ & 11 & $\begin{array}{l}\text { Искусственный жемчуг, драгоценные и полудрагоценные камни, } \\
\text { искусственные и полудрагоценные камни (за исключением } \\
\text { промышленных алмазов) } \\
\text { Ювелирные изделия, другие изделия из драгоценных } \\
\text { металлов/украшенных драгоценными металлами; изделия из } \\
\text { естественного или искусственного жемчуга, драгоценных или } \\
\text { полудрагоценных камней } \\
\text { Натуральный, искусственный и необработанный жемчуг }\end{array}$ \\
\hline & 7220 & & $\begin{array}{l}\text { Исследования и экспериментальные разработки в } \\
\text { области общественных и гуманитарных наук }\end{array}$ & 81229 & 12 & $\begin{array}{l}\text { Услуги в области исследования и разработок в других } \\
\text { гуманитарных областях }\end{array}$ \\
\hline \multirow[b]{2}{*}{ 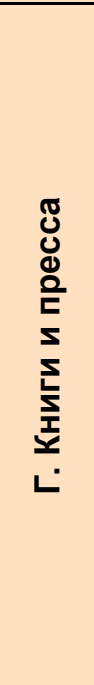 } & 9101 & & Деятельность библиотек и архивов & $\begin{array}{l}84510 \\
84520 \\
\end{array}$ & & $\begin{array}{l}\text { Библиотечные услуги } \\
\text { Архивные услуги }\end{array}$ \\
\hline & 5811 & & Издание книг & $\begin{array}{l}32210 \\
32220 \\
32291 \\
32292 \\
32299 \\
32510 \\
32511 \\
\\
32530 \\
47691 \\
47692 \\
84311\end{array}$ & & $\begin{array}{l}\text { Печатные учебники } \\
\text { Печатные справочники общего характера } \\
\text { Профессиональные, технические и научные печатные книги } \\
\text { Печатные книги для детей } \\
\text { Другие печатные книги, не классифицированные в других } \\
\text { рубриках } \\
\text { Карты, схемы и настенные карты, издающиеся не в книжном } \\
\text { формате } \\
\text { Карты и гидрографические или иные аналогичные схемы } \\
\text { (включая настенные карты, топографические планы и карты для } \\
\text { глобусов), издающиеся не в книжном формате } \\
\text { Печатные или иллюстрированные почтовые открытки, печатные } \\
\text { почтовые открытки с персональными приветствиями или } \\
\text { посланиями с конвертами и обрезкой или без них } \\
\text { Звуковые книги на дисках, магнитофонной пленке или других } \\
\text { носителях } \\
\text { Тексты на дисках, магнитофонной пленке или других носителях } \\
\text { Электронные книги }\end{array}$ \\
\hline
\end{tabular}




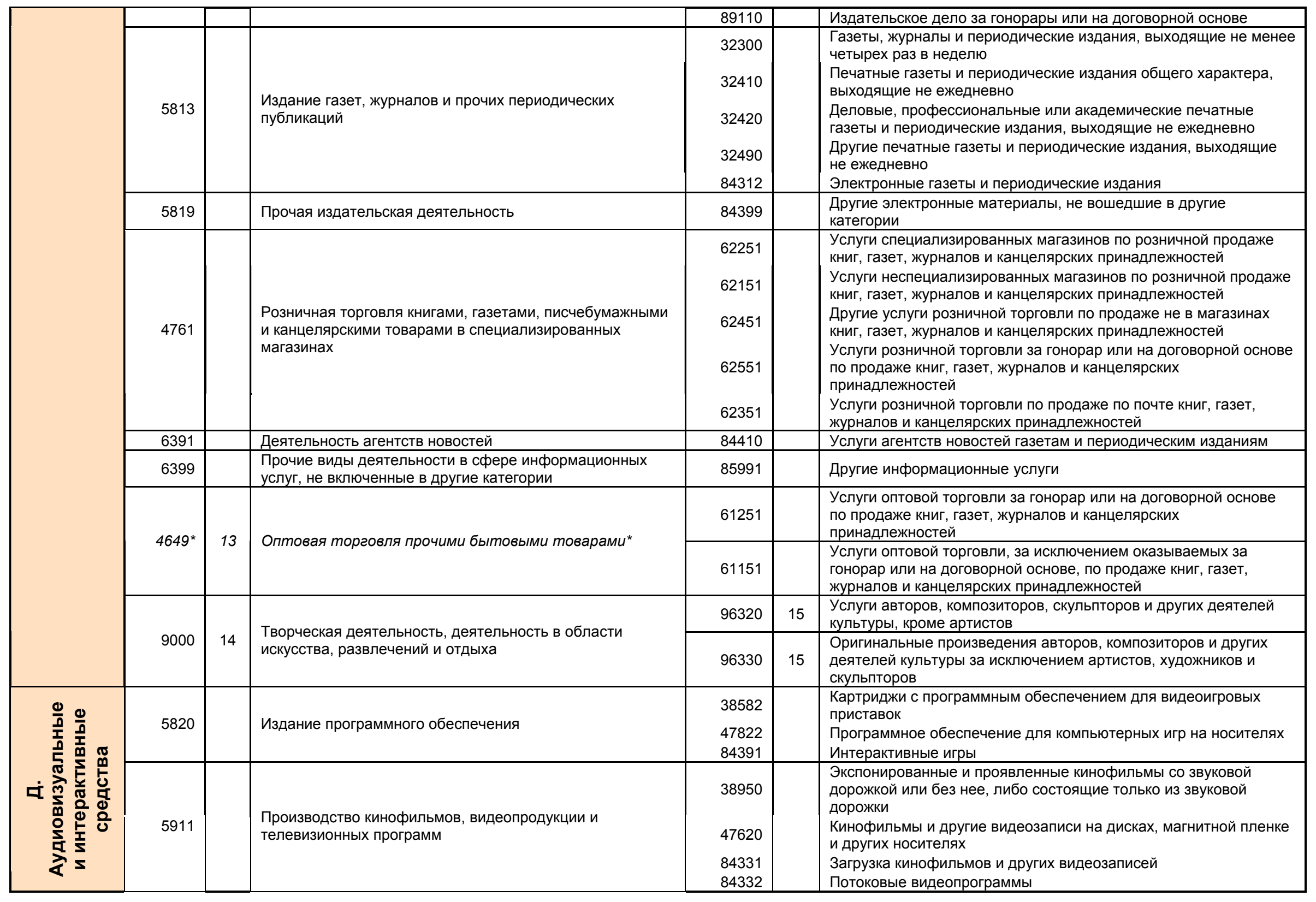









\begin{tabular}{|c|c|c|c|c|c|c|}
\hline \multirow{3}{*}{ 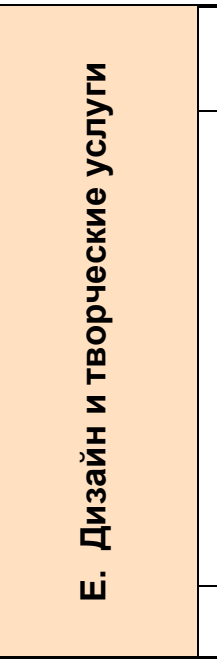 } & 7410 & 16 & $\begin{array}{l}\text { Специализированная проектно-конструкторская } \\
\text { деятельность }\end{array}$ & $\begin{array}{l}83911 \\
83919 \\
83920\end{array}$ & & $\begin{array}{l}\text { Услуги по дизайну интерьера } \\
\text { Другие специализированные услуги в области дизайна } \\
\text { Оригинальный дизайн }\end{array}$ \\
\hline & 7110 & & $\begin{array}{l}\text { Деятельность в области архитектуры и гражданского } \\
\text { строительства и связанные с этим технические } \\
\text { консультации }\end{array}$ & $\begin{array}{l}32550 \\
83211 \\
83212 \\
83213 \\
83214 \\
83231 \\
83232 \\
73390 \\
\end{array}$ & 17 & $\begin{array}{l}\text { Планы и рисунки для архитектурных, инженерных, } \\
\text { промышленных, коммерческих, топографрических или } \\
\text { аналогичных целей, будь то оригиналы, сделанные от руки, } \\
\text { рукописные тексты, фотограффические репродукции и } \\
\text { сделанные под копирку копии перечисленного выше, связанные } \\
\text { с планами и рисунками по архитектуре } \\
\text { Консультационные услуги в области архитектуры } \\
\text { Архитектурные услуги по проектированию жилых зданий } \\
\text { Архитектурные услуги по проектированию нежилых зданий } \\
\text { Услуги по восстановлению памятников архитектуры } \\
\text { Консультационные услуги по ландшафтной архитектуре } \\
\text { Услуги по ландшафтной архитектуре } \\
\text { Услуги по лицензированию прав на использование других } \\
\text { продуктов интеллектуальной собственности }\end{array}$ \\
\hline & 7310 & & Рекламная деятельность & $\begin{array}{l}83611 \\
83619 \\
\end{array}$ & & $\begin{array}{l}\text { Полный цикл услуг по рекламе } \\
\text { Другие рекламные услуги }\end{array}$ \\
\hline \multicolumn{7}{|c|}{ СКВОЗНЫЕ ОБЛАСТИ } \\
\hline $\begin{array}{l}\text { Образование } \\
\text { в области } \\
\text { культуры }^{19}\end{array}$ & \multicolumn{2}{|c|}{$\begin{array}{l}8522^{*} \\
8530^{*} \\
8542\end{array}$} & $\begin{array}{l}\text { Техническое и профессиональное среднее образование* } \\
\text { Высшее образование* } \\
\text { Образование в сфрере культуры }\end{array}$ & 92911 & & Услуги образования в области культуры \\
\hline
\end{tabular}

\section{Примечания:}

1 Категория 7400 МСОК Другая профессиональная, научная и техническая деятельность, не классифицированная в других областях, включает деятельность агентов и агентств в пользу отдельных лиц, обычно связанную с получением работы при съемках кинофильмов, постановкой театральных представлений или других видов развлекательных и спортивных мероприятий, а также с презентацией книг, пьес, произведений искусства, фотографий и т.д. издательствам, продюсерам и т.п. Однако, эта деятельность, рассматривается в данной категории как вспомогательная и поэтому не включается в ССК.

2 Проблемы, связанные с музыкой, определяются тем, что логически она входит в область «Аудиовизуальные и интерактивные средства», а также в «Представления и празднества». В эту категорию в основном включается деятельность, связанная с музыкальными записями. Однако, когда эти категории сочетают деятельность в области аудио-, видео- и вещания, деятельность по оптовому и розничному распространению включается в область «Аудиовизуальные и интерактивные средства».

3 Художественные промыслы: поскольку МСОК охватывает промышленную деятельность, включить в нее измерение художественных промыслов невозможно. Категория 1392 - производство готовых текстильных изделий, за исключением одежды, включает: производство плетеных вручную ковровых изделий; 2825 - производство оборудования для текстиля, одежды и продукции из кожи, включает ткацкие станки, а также прялки.

КОП: КОП не предлагает радикального решения основной проблемы измерения деятельности художественных промыслов в рамках статистических классификаций. Иначе говоря, продукты, обычно определяются по форме или типу (например, «статуэтки и другие керамические изделия», «ковры и другие тканые покрытия пола»), а не по методу их производства, т.е. кустарному или промышленному. Поэтому при нашем подходе применяются категории, в которых использованные материалы и/или типы продуктов указывают на то, связан ли данный вид деятельности с массовым производством или он скорее отражает кустарные промыслы.

4 Исключены работы по реставрации предметов искусства и музейных коллекций (в 9000). 
5 Включена розничная продажа антиквариата. Категория 4773, в которую входит «Деятельность коммерческих картинных галерей, антикварных магазинов и аукционов (розничная)», сюда не включена, поскольку охват этой категории слишком широк.

6 Сюда включены розничные услуги аукционов. В КОП отсутствует специальная категория, охватывающая только подержанные товары.

7 Постановка живых театральных представлений, концертов, оперных и балетных спектаклей и другой сценической продукции; деятельность групп, организация круизов или компаний, оркестров или музыкальных групп; деятельность отдельных мастеров искусств, таких как музыканты, авторы и продюсеры или антрепренеры живых художественных представлений с использованием или без использования специального оборудования.

8 Как и другие классификации, КОП хорошо отражает аудиовизуальную деятельность. Однако и здесь еще существует ряд проблем, связанных с применением классификации для более полного и точного отражения аудиовизуальной деятельности: 73320 - «Услуги по лицензированию прав на использование развлекательных, литературных и звуковых оригиналов» охватывает как аудиовизуальную деятельность, так и деятельность в других областях культуры. Чтобы определить, как точнее классифицировать деятельность в рамках этой категории в разных областях, требуются эмпирические исследования в отдельных странах.

9 Включает деятельность скульпторов, художников, карикатуристов, граверов, офортистов и т.д., а также реставрационные работы таких произведений искусства, как картины и т.д.

10 Деятельность по распространению, связанная с фотографией (оптовой и розничной) в КОП детализирована недостаточно, поскольку она объединена с «Оптикой и особо точной техникой». Поэтому эти категории в областях культуры пропущены.

11 Жемчуг рассматривается только в ювелирном производстве и кустарных промыслах.

12 Включает услуги по исследованиям и экспериментальным разработкам, связанным с историей, философией, искусством, религией, теологией и Т.Д.

13 Включает оптовую торговлю канцелярскими принадлежностями, книгами, журналами и газетами.

14 Включает деятельность писателей и независимых журналистов.

15 Эта категория проблематична, поскольку наряду с четко выраженной работой авторов, она охватывает многие другие виды (индивидуальной) культурной творческой деятельности. Чтобы определить, как точнее классифицировать деятельность в рамках этой категории в разных областях, требуются эмпирические исследования в отдельных странах.

16 Включает: дизайн моды, связанный с тканями, одеждой, обувью, ювелирными украшениями, мебелью, другим внутренним убранством и модными товарами, а также другими личными или домашними товарами, сделанными графическими дизайнерами или декораторами интерьера. Необходимо оценивать ту часть, которая связана с архитектурной деятельностью. В категориях МСОК не проводится различий между разными типами архитектурной деятельности (ландшафтной, реставрации исторических памятников и т.д.)

17 Категорию 32550 («Планы и рисунки для архитектурных, инженерных, промышленных, коммерческих, топографических или аналогичных целей, будь то оригиналы, сделанные от руки, рукописные тексты, фотографические репродукции и сделанные под копирку копии перечисленного выше, связанные с планами и рисунками по архитектуре») следует включать лишь в том случае, если в стране нет возможности провести различие между продуктами, относящимися и не относящимися к культуре.

18 Эта категория включает: услуги по лицензированию прав на использование других видов продуктов интеллектуальной собственности, таких как архитектурные и инженерные планы, промышленный дизайн и т.д.

19 Включает образование и подготовку, связанные с постановкой театрализованных представлений, концертных, оперных и балетных спектаклей и другой сценической продукции; деятельность групп, организация круизов или компаний, оркестров или музыкальных групп; деятельность отдельных мастеров искусств, таких как музыканты, авторы; и деятельность продюсеров или антрепренеров живых художественных представлений с использованием или без использования специального оборудования. 


\begin{tabular}{|c|c|c|c|c|}
\hline \multicolumn{5}{|c|}{ ДОПОЛНИТЕЛЬНЫЕ ОБЛАСТИ } \\
\hline \multirow{2}{*}{ Область } & \multicolumn{2}{|r|}{ Производственная деятельность } & \multicolumn{2}{|r|}{ Товары и услуги } \\
\hline & МСОК 4 & Описание & коП 2 & Описание \\
\hline \multirow{6}{*}{ 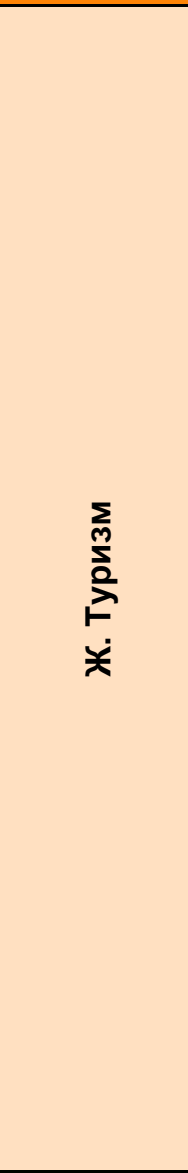 } & $\begin{array}{l}4911^{*} \\
4922^{*} \\
5011 \\
5110\end{array}$ & $\begin{array}{l}\text { Пассажирский железнодорожный транспорт } \\
\text { междугородного сообщения* } \\
\text { Прочий пассажирский сухопутный транспорт } \\
\text { Морской и каботажный пассажирский водный транспорт } \\
\text { Воздушный пассажирский транспорт }\end{array}$ & $\begin{array}{l}64131 \\
64132 \\
64133 \\
64134\end{array}$ & $\begin{array}{l}\text { Услуги по осмотру достопримечательностей с путешествием по } \\
\text { железной дороге } \\
\text { Услуги по осмотру достопримечательностей с наземным } \\
\text { путешествием за исключением железной дороги } \\
\text { Услуги по осмотру достопримечательностей с путешествием по } \\
\text { воде } \\
\text { Услуги по осмотру достопримечательностей с путешествием по } \\
\text { воздуху }\end{array}$ \\
\hline & 5510 & Деятельность по кратковременному размещению & $\begin{array}{l}63111 \\
63112 \\
63113 \\
63114\end{array}$ & $\begin{array}{l}\text { Услуги по ежедневному обслуживанию комнат или номеров для } \\
\text { приезжих } \\
\text { Услуги без ежедневного обслуживания комнат или номеров для } \\
\text { приезжих } \\
\text { Услуги по предоставлению комнат или номеров для приезжих в } \\
\text { жилых помещениях с ограниченным временем права } \\
\text { собственности } \\
\text { Услуги по размещению приезжих в комнатах на несколько } \\
\text { человек }\end{array}$ \\
\hline & 5520 & $\begin{array}{l}\text { Площадки для кемпингов, стоянки для рекреационных } \\
\text { транспортных средств и дач-прицепов }\end{array}$ & $\begin{array}{l}63120 \\
63130 \\
\end{array}$ & $\begin{array}{l}\text { Услуги кемпингов } \\
\text { Услуги кемпингов во время оздоровительных отпусков }\end{array}$ \\
\hline & 7911 & Деятельность бюро путешествий & $\begin{array}{l}85511 \\
85521 \\
85523 \\
85524 \\
\end{array}$ & $\begin{array}{l}\text { Услуги по бронированию билетов на самолет } \\
\text { Услуги по бронированию жилых помещений } \\
\text { Услуги по бронированию круизов } \\
\text { Услуги по бронированию групповых туров }\end{array}$ \\
\hline & 7912 & Деятельность туристических агентств & 85540 & Услуги туристических агентств \\
\hline & 7990 & $\begin{array}{l}\text { Прочие услуги по бронированию и связанные с этим виды } \\
\text { деятельности }\end{array}$ & $\begin{array}{l}85512 \\
85513 \\
85514 \\
85519 \\
85539 \\
85550 \\
85561 \\
85562 \\
\end{array}$ & $\begin{array}{l}\text { Услуги по бронированию билетов на поезд } \\
\text { Услуги по бронированию билетов на автобус } \\
\text { Услуги по бронированию арендуемых автомобилей } \\
\text { Другие транспортные услуги по бронированию, не } \\
\text { классифицированные в других рубриках } \\
\text { Услуги по бронированию билетов на мероприятия и } \\
\text { развлечения, оздоровительные и другие услуги } \\
\text { Услуги гидов-сопровождающих } \\
\text { Услуги по развитию туризма } \\
\text { Информационные услуги для туристов } \\
\end{array}$ \\
\hline & 5520 & $\begin{array}{l}\text { Площадки для кемпингов, стояки для рекреационных } \\
\text { транспортных средств и дач-прицепов }\end{array}$ & 63130 & Услуги кемпингов во время оздоровительных отпусков \\
\hline & 7721 & $\begin{array}{l}\text { Аренда и лизинг товаров для досуга и отдыха и спортивного } \\
\text { инвентаря }\end{array}$ & 73240 & Услуги по аренде оборудования для развлечений и досуга \\
\hline & 9311 & Эксплуатация спортивных сооружений & 96520 & $\begin{array}{l}\text { Услуги по предоставлению оздоровительного и спортивного } \\
\text { инвентаря }\end{array}$ \\
\hline & 9312 & Деятельность спортивных клубов & 96512 & Услуги спортивных клубов \\
\hline
\end{tabular}




\begin{tabular}{|c|c|c|c|c|}
\hline \multirow{6}{*}{$\begin{array}{l}\text { 눙 } \\
\text { o } \\
\text { ㅁ } \\
\mathbf{5} \\
\text { 응 } \\
\text { 드 } \\
\text { mं }\end{array}$} & 9319 & Прочая спортивная деятельность & $\begin{array}{l}96511 \\
96590 \\
96610 \\
96620\end{array}$ & $\begin{array}{l}\text { Услуги по развитию спорта и оздоровительных спортивных } \\
\text { мероприятий } \\
\text { Другие услуги, связанные со спортом и активным отдыхом } \\
\text { Услуги спортсменов } \\
\text { Дополнительные услуги, связанные со спортом и активным } \\
\text { отдыхом }\end{array}$ \\
\hline & 9200 & $\begin{array}{l}\text { Деятельность по организации и проведению азартных игр и } \\
\text { пари }\end{array}$ & $\begin{array}{l}96921 \\
96929\end{array}$ & $\begin{array}{l}\text { Услуги по азартным играм через Интернет } \\
\text { Услуги по другим азартным играм и заключению пари }\end{array}$ \\
\hline & 9321 & Деятельность парков отдыха и аттракционов & 96910 & Услуги парков с аттракционами \\
\hline & 9329 & $\begin{array}{l}\text { Прочая деятельность по организации досуга и развлечений, } \\
\text { не включенная в другие категории }\end{array}$ & $\begin{array}{l}96990 \\
96930 \\
\end{array}$ & $\begin{array}{l}\text { Другие оздоровительные и развлекательные услуги, не } \\
\text { классифицированные в других рубриках } \\
\text { Услуги игральных автоматов, работающих при опускании монет }\end{array}$ \\
\hline & 9609 & $\begin{array}{l}\text { Предоставление прочих персональных услуг, не включенных в } \\
\text { другие категории }\end{array}$ & 97230 & Услуги по физической подготовке \\
\hline & 8541 & Образование в сфере спорта и досуга & 92912 & Услуги образования в области спорта и развлечений \\
\hline
\end{tabular}




\begin{tabular}{|c|c|c|c|c|c|}
\hline \multirow{2}{*}{ Область } & & $\begin{array}{l}\text { ТВУЮЩИЕ МАТЕРИАЛЫ ОБЛАСТЕЙ КУЛЬТ } \\
\text { ПроИЗВОДстВеНная ДеяТеЛЬНОстЬ }\end{array}$ & \multicolumn{3}{|r|}{ Товары и услуги } \\
\hline & Мсок 4 & Описание & коп 2 & & Описание \\
\hline $\begin{array}{l}\text { Б. } \\
\text { Представления } \\
\text { и празднества }\end{array}$ & $\begin{array}{l}1820 \\
3290^{*} \\
2640^{*}\end{array}$ & $\begin{array}{l}\text { Тиражирование носителей записи } \\
\text { Производство прочих готовых изделий, не включенных в } \\
\text { другие категории } \\
\text { Производство потребительской электронной } \\
\text { аппаратуры }\end{array}$ & $\begin{array}{l}89123 \\
38991 \\
47321\end{array}$ & 1 & $\begin{array}{l}\text { Услуги по воспроизведению записей за гонорар или на } \\
\text { контрактной основе } \\
\text { Праздничная, карнавальная или другая развлекательная } \\
\text { деятельность, включая фокусы и клоунаду } \\
\text { Оборудование для записи или воспроизведения звука }\end{array}$ \\
\hline \multirow{3}{*}{ 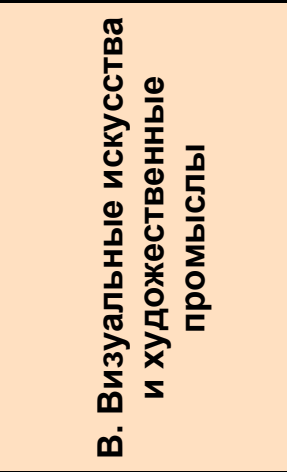 } & $2022^{*}$ & $\begin{array}{l}\text { Производство красок, олифы и аналогичных покрытий, } \\
\text { типографрской краски и мастик* }\end{array}$ & 35120 & & $\begin{array}{l}\text { Краски, растворители и т.д. для художников, живописцев, } \\
\text { учащихся }\end{array}$ \\
\hline & $2670^{*}$ & $\begin{array}{l}\text { Производство оптических инструментов и } \\
\text { фотоооборудования }\end{array}$ & $\begin{array}{l}46520 \\
48321 \\
48322 \\
48324\end{array}$ & & $\begin{array}{l}\text { Фотовспышки и аналогичные устройства } \\
\text { Линзы для объективов фотоаппаратов, проекторов или } \\
\text { фотоувеличителей } \\
\text { Фотокамеры (включая кинематографические) } \\
\text { Вспышки для фотоаппаратов, включая импульсные лампы; } \\
\text { фотоувеличители (за исключением кинематографрических); } \\
\text { оборудование для фотолабораторий, не } \\
\text { классифицированные в других рубриках; негатоскопы и } \\
\text { проекционные экраны }\end{array}$ \\
\hline & $2029^{*}$ & $\begin{array}{l}\text { Производство прочих химических продуктов, не } \\
\text { включенных в другие } \\
\text { категории, не классифрицированные в других рубриках* }\end{array}$ & $\begin{array}{l}48341 \\
48342 \\
\end{array}$ & & $\begin{array}{l}\text { Фотографические пластины, пленка и самопроявляющаяся } \\
\text { пленка, светочувствительная, неэкспонированная } \\
\text { Химические препараты для использования в фотографии }\end{array}$ \\
\hline \multirow{4}{*}{ 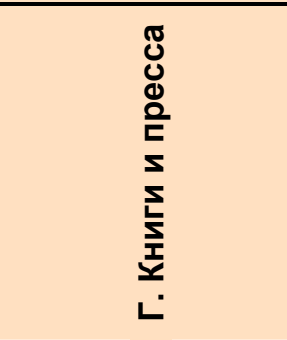 } & 5813 & Издание газет, журналов и периодических публикаций & 83631 & & $\begin{array}{l}\text { Продажа рекламного пространства в печатных изданиях (за } \\
\text { исключением комиссионных) }\end{array}$ \\
\hline & 1811 & Полиграфическая деятельность & 89121 & & Печатные услуги \\
\hline & 1812 & Услуги, связанные с полиграфрической деятельностью & $\begin{array}{l}89122 \\
32800\end{array}$ & & $\begin{array}{l}\text { Сопутствующие печатные услуги } \\
\text { Набор шрифтов, подготовка форменных пластин или } \\
\text { цилиндров, литографические печатные машины и другие } \\
\text { печатные средства }\end{array}$ \\
\hline & $2829^{*}$ & Производство прочих машин специального назначения* & 44914 & & $\begin{array}{l}\text { Брошюровочно-переплетные машины; наборное и другое } \\
\text { оборудование; печатное и вспомогательное оборудование } \\
\text { (за исключением листовых офрсетных печатных машин) }\end{array}$ \\
\hline
\end{tabular}




\begin{tabular}{|c|c|c|c|c|}
\hline \multirow{18}{*}{ 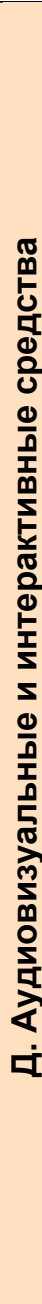 } & $2610^{*}$ & Производство прочих машин специального назначения* & 45281 & $\begin{array}{l}\text { Звуковые, видео, сетевые и аналогичные устройства для } \\
\text { оборудования автоматической обработки данных }\end{array}$ \\
\hline & & & 45221 & $\begin{array}{l}\text { Портативные устройства автоматической обработки данных } \\
\text { весом не более } 10 \text { кг, такие как лаптопы и ноутбуки }\end{array}$ \\
\hline & & & 45222 & $\begin{array}{l}\text { Персональные цифровые записные книжки и аналогичные } \\
\text { компьютеры }\end{array}$ \\
\hline & & & 45230 & $\begin{array}{l}\text { Устройства автоматической обработки данных в одном } \\
\text { корпусе объединяющие, по крайней мере, центральный } \\
\text { процессор и устройство для входных и выходных сигналов в } \\
\text { собранном или разобранном виде }\end{array}$ \\
\hline & & & 45240 & $\begin{array}{l}\text { Устройства автоматической обработки данных в форме } \\
\text { систем }\end{array}$ \\
\hline & & & 47550 & $\begin{array}{l}\text { Транзисторные энергонезависимые устройства хранения } \\
\text { данных }\end{array}$ \\
\hline & 2620 & $\begin{array}{l}\text { Производство компьютеров и перифрерийного } \\
\text { оборудования }\end{array}$ & 45250 & $\begin{array}{l}\text { Другие устройства автоматической обработки данных, } \\
\text { содержащие или нет в одном корпусе один или два } \\
\text { следующих узла: устройства для хранения данных, входное } \\
\text { устройство, выходное устройство }\end{array}$ \\
\hline & & & 45261 & $\begin{array}{l}\text { Периферийные устройства ввода (клавиатура, джойстик, } \\
\text { мышка и т.п.) }\end{array}$ \\
\hline & & & 45271 & Жесткие диски \\
\hline & & & 45272 & Съемные носители информации \\
\hline & & & $\begin{array}{l}45289 \\
45290\end{array}$ & $\begin{array}{l}\text { Другие узлы устройств автоматической обработки данных } \\
\text { Узлы и дополнительные принадлежности для компьютеров }\end{array}$ \\
\hline & & & 47314 & $\begin{array}{l}\text { телевизионные приемники и в основном не используемые с } \\
\text { системами автоматической обработки данных }\end{array}$ \\
\hline & & & 47315 & $\begin{array}{l}\text { Мониторы и проекционные аппараты, в основном } \\
\text { используюмые с системами автоматической обработки } \\
\text { данных }\end{array}$ \\
\hline & & & 88742 & $\begin{array}{l}\text { Услуги по производству компьютеров и сопутствующего } \\
\text { оборудования }\end{array}$ \\
\hline & & & 47211 & $\begin{array}{l}\text { Передающие устройства, включающие приемные } \\
\text { устройства }\end{array}$ \\
\hline & 2630 & Производство оборудования связи & 47212 & Передающие устройства, не включающие приемные \\
\hline & & & 47213 & Телевизионные камеры \\
\hline & & & 47403 & $\begin{array}{l}\text { Части и товары подкатегорий с } 47211 \text { по 47213, с } 47311 \text { по } \\
47315 \text { и } 48220\end{array}$ \\
\hline
\end{tabular}




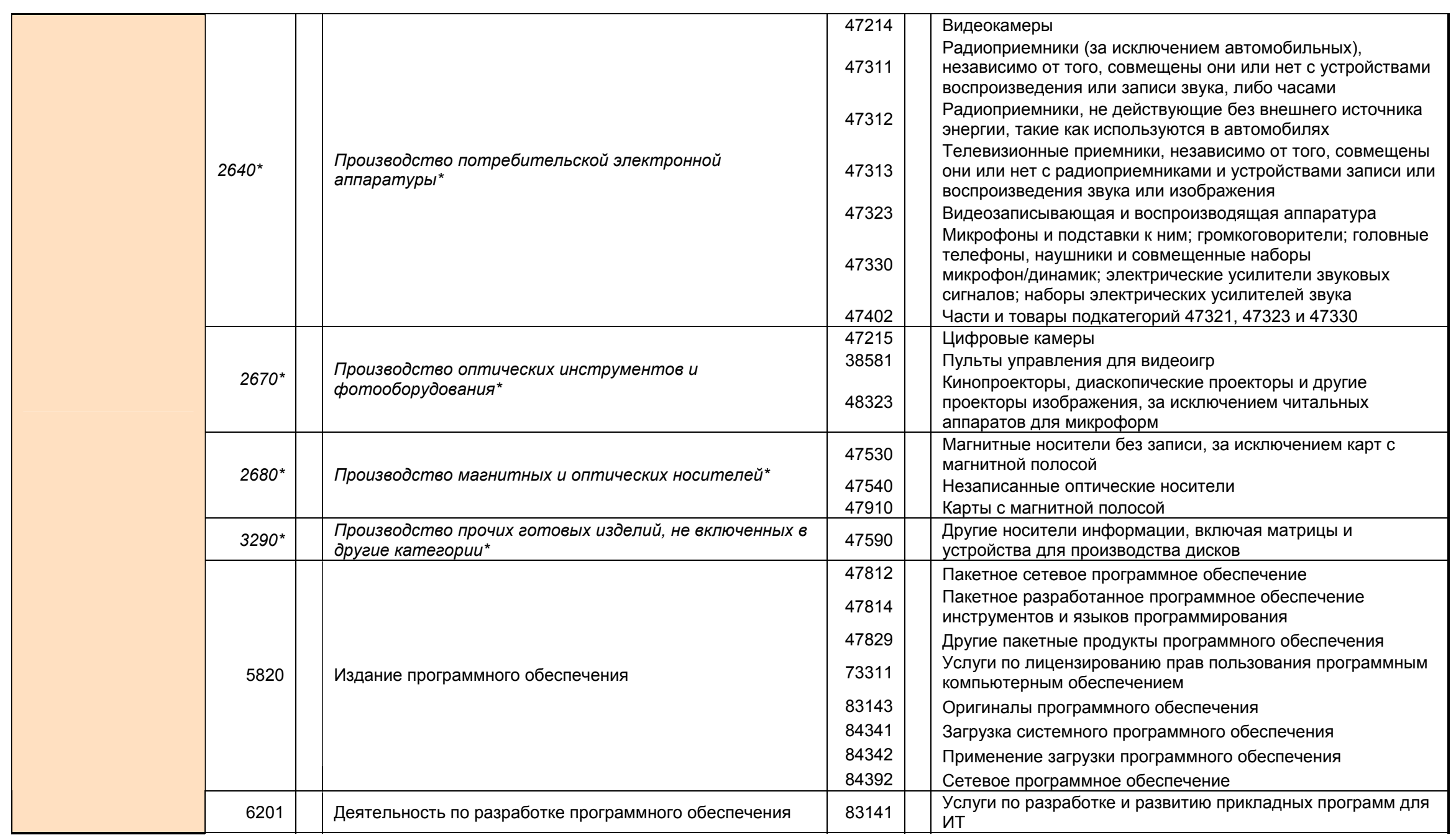




\begin{tabular}{|c|c|c|c|c|c|}
\hline & 6202 & & $\begin{array}{l}\text { Консультационная деятельность, связанная с } \\
\text { компьютерами, и деятельность по управлению } \\
\text { компьютерным оборудованием }\end{array}$ & $\begin{array}{l}83142 \\
83161\end{array}$ & $\begin{array}{l}\text { Услуги по разработке и развитию сетей и систем для ИТ } \\
\text { Услуги по поддержке сети }\end{array}$ \\
\hline & 6020 & & Создание телевизионных программ и телевещание & 83632 & $\begin{array}{l}\text { Продажа рекламного времени на телевидении и радио (за } \\
\text { исключением комиссионных) }\end{array}$ \\
\hline & 6110 & & Деятельность в сфере проводной связи & $\begin{array}{l}84210 \\
84221 \\
84222\end{array}$ & $\begin{array}{l}\text { Магистральные сетевые услуги в Интернете } \\
\text { Услуги по доступу к узкополосному Интернету } \\
\text { Услуги по доступу к широкополосному Интернету }\end{array}$ \\
\hline & 6120 & & Деятельность в сфере беспроводной связи & 84290 & Другие телекоммуникационные услуги в Интернете \\
\hline & $6311^{*}$ & 2 & $\begin{array}{l}\text { Обработка данных, хостина и связанные с ними виды } \\
\text { деятельности* }\end{array}$ & $\begin{array}{l}83151 \\
83152 \\
83159 \\
\end{array}$ & $\begin{array}{l}\text { Услуги по созданию и обслуживанию веб-сайтов } \\
\text { Услуги сервера приложений } \\
\text { Другие услуги и инфраструктура ИТ }\end{array}$ \\
\hline & 6312 & & Веб-порталы & 83633 & $\begin{array}{l}\text { Продажа пространства в Интернете (за исключением } \\
\text { комиссионных) }\end{array}$ \\
\hline & $7730^{*}$ & & $\begin{array}{l}\text { Аренда и лизине прочих машин, оборудования и } \\
\text { материальных ценностей }\end{array}$ & $\begin{array}{l}73124 \\
73210\end{array}$ & $\begin{array}{l}\text { Услуги по аренде компьютеров без операторов } \\
\text { Услуги по аренде телевизоров, радиоприемников, } \\
\text { видеомагнитофонов и сопутствующего оборудования и } \\
\text { аксессуаров }\end{array}$ \\
\hline & 4742 & & $\begin{array}{l}\text { Розничная торговля аудио- и видеоаппаратурой в } \\
\text { специализированных } \\
\text { магазинах }\end{array}$ & 62242 & $\begin{array}{l}\text { Услуги специализированных магазинов по розничной } \\
\text { продаже радио- и телевизионного оборудования и аудио- и } \\
\text { видеозаписей и пленок }\end{array}$ \\
\hline & $\begin{array}{r}4651 \\
4652^{*}\end{array}$ & 3 & $\begin{array}{l}\text { Оптовая торговля компьютерами, периферийным } \\
\text { оборудованием и про- } \\
\text { граммным обеспечением } \\
\text { Оптовая торговля электронным и } \\
\text { телекоммуникационным оборудованием и деталями для } \\
\text { него* }\end{array}$ & $\begin{array}{l}61184 \\
61185\end{array}$ & $\begin{array}{l}\text { Компьютеры и пакетное программное обеспечение } \\
\text { Электронное и телекоммуникационное оборудование и } \\
\text { детали }\end{array}$ \\
\hline & 9511 & & Ремонт компьютеров и периферийного оборудования & 87130 & $\begin{array}{l}\text { Услуги по ремонту и обслуживанию компьютеров и } \\
\text { периферийного оборудования }\end{array}$ \\
\hline & $3320^{*}$ & & Монтаж промышленных машин и оборудования* & 87340 & $\begin{array}{l}\text { Услуги по установке радиоприемников, телевизоров и } \\
\text { коммуникационного оборудования и устройств }\end{array}$ \\
\hline & 6209 & & $\begin{array}{l}\text { Прочие виды деятельности в сфере информационных } \\
\text { технологий и обслуживания компьютерной техники }\end{array}$ & 87332 & $\begin{array}{l}\text { Услуги по установке персональных компьютеров и } \\
\text { периферийного оборудования }\end{array}$ \\
\hline $\begin{array}{l}\text { Е. Дизайн и } \\
\text { творческие } \\
\text { услуги }\end{array}$ & 7310 & & Рекламная деятельность & $\begin{array}{l}83620 \\
83639\end{array}$ & $\begin{array}{l}\text { Покупка или продажа рекламного пространства или времени } \\
\text { за комиссионные } \\
\text { Продажа другого рекламного пространства и времени (за } \\
\text { исключением комиссионных) }\end{array}$ \\
\hline
\end{tabular}

\section{Примечания:}

1 Сюда следует включать только звукозаписывающую аппаратуру для музыки.

2 Не следует включать деятельность, связанную с обработкой данных.

3 Сюда включается «Оптовая продажа записанных аудио- и видео пленок, CD и DVD». B эту категорию также включается оптовая продажа потребительской электроники: радио- и телевизионное оборудование; проигрыватели и записывающие устройства для CD и DVD; оборудование для стерео записи и воспроизведения; приставки для компьютерных игр. 


\begin{tabular}{|c|c|c|c|c|}
\hline \multicolumn{5}{|c|}{ ОБОРУДОВАНИЕ И СОПУТСТВУЮЩИЕ МАТЕРИАЛЫ ДОПОЛНИТЕЛЬНЫХ ОБЛАСТЕЙ } \\
\hline \multirow[b]{2}{*}{ Область } & \multicolumn{2}{|r|}{ Производственная деятельность } & \multirow[b]{2}{*}{ коп 2} & \multirow[b]{2}{*}{ Описание } \\
\hline & $\begin{array}{c}\text { MCOK } \\
4\end{array}$ & Описание & & \\
\hline \multirow{8}{*}{  } & $1410^{*}$ & Производство одежды, кроме меховой одежды* & 28228 & $\begin{array}{l}\text { Тренировочные костюмы, лыжные костюмы, купальные } \\
\text { костюмы и другие трикотажные или вязаные предметы } \\
\text { одежды, не классифицированные в других рубриках } \\
\text { Тренировочные костюмы, лыжные костюмы, купальные } \\
\text { костюмы и другие предметы одежды из тканых, но не } \\
\text { вязаных материалов }\end{array}$ \\
\hline & $2829^{*}$ & Производство прочих машин специального назначения* & 38600 & $\begin{array}{l}\text { Карусели, качели, тиры и другие развлекательные } \\
\text { аттракционы }\end{array}$ \\
\hline & $1520^{*}$ & Производство обуви* & $\begin{array}{l}29420 \\
29490 \\
\end{array}$ & $\begin{array}{l}\text { Обувь для игры в теннис, баскетбол, занятий гимнастикой, } \\
\text { тренировок и другие виды обуви } \\
\text { Другая спортивная обувь кроме ботинок для коньков }\end{array}$ \\
\hline & 3012 & Строительство прогулочных и спортивных лодокдок & $\begin{array}{l}49410 \\
49490\end{array}$ & $\begin{array}{l}\text { Парусные лодки (кроме надувных) с дополнительным } \\
\text { двигателем или без него } \\
\text { Другие виды развлечений или спорта; гребные шлюпки и } \\
\text { каноэ }\end{array}$ \\
\hline & 3230 & Производство спортивных товаров & $\begin{array}{l}38410 \\
38420 \\
38430 \\
38440 \\
38450 \\
29410 \\
\end{array}$ & $\begin{array}{l}\text { Лыжи и другое оборудование для катания по снегу; коньки } \\
\text { и ролики } \\
\text { Водные лыжи, доски для серфинга, парусные доски и } \\
\text { другое оборудования для водных видов спорта } \\
\text { Предметы и оборудование для гимнастических залов или } \\
\text { занятий спортом } \\
\text { Другие предметы и оборудование для занятий спортом или } \\
\text { игр на открытом воздухе } \\
\text { Удочки и другие рыболовные снасти; рыболовные сачки, } \\
\text { сачки для бабочек и другие сачки } \\
\text { Лыжные ботинки и ботинки для сноуборда }\end{array}$ \\
\hline & 4763 & $\begin{array}{l}\text { Розничная торговля спортивным инвентарем в } \\
\text { специализированных магазинах }\end{array}$ & 62255 & $\begin{array}{l}\text { Услуги розничной торговли специализированных магазинов } \\
\text { по продаже спортивных товаров (включая велосипеды) }\end{array}$ \\
\hline & $4290^{*}$ & Возведение прочих объектов гражданского строительства* & 53270 & $\begin{array}{l}\text { Оборудование для занятий спортом и отдыха на открытом } \\
\text { воздухе }\end{array}$ \\
\hline & $4791^{*}$ & $\begin{array}{l}\text { Розничная торговля через фрирмы, выполняющие заказы по } \\
\text { почте, или через Интернет* }\end{array}$ & 62355 & $\begin{array}{l}\text { Услуги розничной торговли по продаже по почте или } \\
\text { Интернету спортивных товаров (включая велосипеды) }\end{array}$ \\
\hline
\end{tabular}


Таблица 3. Международная торговля культурными товарами и услугами, определяемая с помощью категорий Гармонизированной системы (ГС) 2007 г.

\begin{tabular}{|c|c|c|c|c|}
\hline \multicolumn{5}{|c|}{ КУЛЬТУРНЫЕ ТОВАРЫ } \\
\hline Область & ГС 07 & Описание & $\begin{array}{c}\text { CKMT } \\
4\end{array}$ & Описание \\
\hline \multicolumn{5}{|c|}{ А. Культурное и природное наследие } \\
\hline \multirow[t]{2}{*}{ 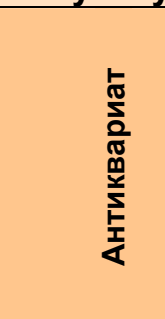 } & 970500 & $\begin{array}{l}\text { Коллекции и коллекционные предметы, представляющие зоологический, } \\
\text { ботанический, минералогический, анатомический, исторический, } \\
\text { археологический, палеонтологический, этнографрический или нумизматический } \\
\text { интерес }\end{array}$ & $89650^{*}$ & $\begin{array}{l}\text { Коллекции и коллекционные предметы, } \\
\text { представляющие зоологический, } \\
\text { ботанический, минералогический, } \\
\text { анатомический, исторический, } \\
\text { археологический, палеонтологический, } \\
\text { этнографический или нумизматический } \\
\text { интерес }\end{array}$ \\
\hline & 970600 & Предметы антиквариата, возраст которых превышает сто лет & 89660 & $\begin{array}{l}\text { Предметы антиквариата, возраст которых } \\
\text { превышает сто лет }\end{array}$ \\
\hline \multicolumn{5}{|c|}{ Б. Представления и празднества } \\
\hline \multirow{8}{*}{  } & 830610 & Колокола, гонги и т.п. & 69952 & $\begin{array}{l}\text { Колокола, гонги и т.п., не электрические, и их } \\
\text { части из основного металла }\end{array}$ \\
\hline & $\begin{array}{l}920110 \\
920120 \\
920190\end{array}$ & $\begin{array}{l}\text { Пианино } \\
\text { Рояли } \\
\text { Клавесины и другие клавишные струнные инструменты (за исключением } \\
\text { пианино и роялей) }\end{array}$ & 89813 & $\begin{array}{l}\text { Пианино (включая автоматические пианино) } \\
\text { и другие клавишные струнные инструменты }\end{array}$ \\
\hline & 920210 & $\begin{array}{l}\text { Другие струнные музыкальные инструменты (например, скрипки, арфы), на } \\
\text { которых играют смычком } \\
\text { Гитары, арфы и другие струнные музыкальные инструменты (за исключением } \\
\text { клавишных и тех, на которых играют смычком) }\end{array}$ & 89815 & $\begin{array}{l}\text { Другие струнные музыкальные инструменты } \\
\text { (например, гитары, скрипки, арфры) }\end{array}$ \\
\hline & $\begin{array}{l}920510 \\
920590 \\
\end{array}$ & $\begin{array}{l}\text { Медные духовые инструменты (например, кларнеты, трубы, волынки) } \\
\text { Духовые музыкальные инструменты (за исключением медных духовых } \\
\text { инструментов) }\end{array}$ & 89823 & $\begin{array}{l}\text { Другие духовые музыкальные инструменты } \\
\text { (например, кларнеты, трубы, волынки) }\end{array}$ \\
\hline & 920600 & $\begin{array}{l}\text { Ударные музыкальные инструменты (например, барабаны, ксилофроны, } \\
\text { цимбалы, кастаньеты, маракасы) }\end{array}$ & 89824 & $\begin{array}{l}\text { Ударные музыкальные инструменты } \\
\text { (например, барабаны, ксилофоны, цимбалы, } \\
\text { кастаньеты, маракасы) }\end{array}$ \\
\hline & 920710 & Клавишные инструменты, отличные от аккордеонов & 89825 & $\begin{array}{l}\text { Клавишные инструменты (отличные от } \\
\text { аккордеонов), звук которых производится } \\
\text { или должен усиливаться электрически } \\
\text { (например, органы) }\end{array}$ \\
\hline & 920790 & $\begin{array}{l}\text { Аккордеоны и музыкальные инструменты без клавиш, звук которых } \\
\text { производится или должен усиливаться электрически }\end{array}$ & 89826 & $\begin{array}{l}\text { Музыкальные инструменты, не указанные в } \\
\text { другом месте, звук которых производится } \\
\text { или должен усиливаться электрически } \\
\text { (например, гитары, аккордеоны) }\end{array}$ \\
\hline & 920890 & $\begin{array}{l}\text { Музыкальные шкатулки } \\
\text { Шарманки, механические шарманки, механические певчие птицы, } \\
\text { музыкальные пилы и другие музыкальные инструменты; манки всех типов; } \\
\text { свистки, рога и другие сигнальные духовые инструменты }\end{array}$ & 89829 & $\begin{array}{l}\text { Музыкальные шкатулки шарманки, } \\
\text { механические шарманки, механические } \\
\text { певчие птицы, музыкальные пилы и другие } \\
\text { музыкальные инструменты, не указанные в } \\
\text { другом месте; манки всех типов; свистки, } \\
\text { рога и другие сигнальные духовые } \\
\text { инструменты }\end{array}$ \\
\hline
\end{tabular}




\begin{tabular}{|c|c|c|c|c|c|}
\hline \multirow{4}{*}{ 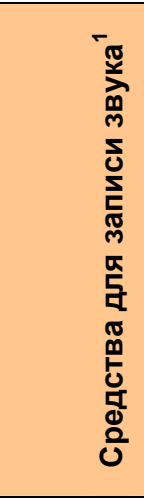 } & $\begin{array}{l}852321 \\
852329\end{array}$ & & $\begin{array}{l}\text { Карты с магнитной полосой } \\
\text { Магнитные носители для записи звука или другой информации (за } \\
\text { исключением карт с магнитной полосой и товаров раздела 37) }\end{array}$ & 89842 & Магнитные носители \\
\hline & $\begin{array}{l}852351 \\
852359\end{array}$ & & $\begin{array}{l}\text { Транзисторные энергонезависимые устройства хранения данных } \\
\text { Незаписанные полупроводниковые средства для записи звука или другой } \\
\text { информации }\end{array}$ & 89846 & Полупроводниковые средства \\
\hline & 852380 & & $\begin{array}{l}\text { Патефонные записи и другие средства для записи звука и другой информации, } \\
\text { записанные или чистые, включая матрицы и первые оригиналы для } \\
\text { производства пластинок }\end{array}$ & 89849 & $\begin{array}{l}\text { Другие пластинки, пленки, транзисторные } \\
\text { энергонезависимые устройства хранения данных, } \\
\text { карточки со встроенными микропроцессами и } \\
\text { другие средства записи звука или другой } \\
\text { информации, записанные или чистые, включая } \\
\text { матрицы и первые оригиналы для производства } \\
\text { пластинок, но исключая продукты группы } 882 \\
\end{array}$ \\
\hline & 490400 & & $\begin{array}{l}\text { Музыкальные записи, печатные или рукописные, переплетенные и } \\
\text { иллюстрированные или нет }\end{array}$ & 89285 & $\begin{array}{l}\text { Музыкальные записи, печатные или } \\
\text { рукописные, переплетенные и } \\
\text { иллюстрированные или нет }\end{array}$ \\
\hline \multicolumn{6}{|c|}{ В. Визуальные искусства и художественные промыслы } \\
\hline \multirow{3}{*}{  } & 970110 & & $\begin{array}{l}\text { Картины, рисунки и пастели, выполненные полностью от руки, кроме рисунков } \\
\text { категории 4906, а также не относящиеся к разрисованным и украшенным } \\
\text { вручную промышленным товарам, коллажам и аналогичным декоративным } \\
\text { рисункам }\end{array}$ & 89611 & Картины, рисунки и пастели \\
\hline & 970190 & & Коллажи и аналогичные декоративные рисунки & 89612 & $\begin{array}{l}\text { Коллажи и аналогичные декоративные } \\
\text { рисунки }\end{array}$ \\
\hline & 491191 & 2 & Картины, рисунки и фотографии & 89287 & Картины, рисунки и фотографиии \\
\hline \multirow{7}{*}{ 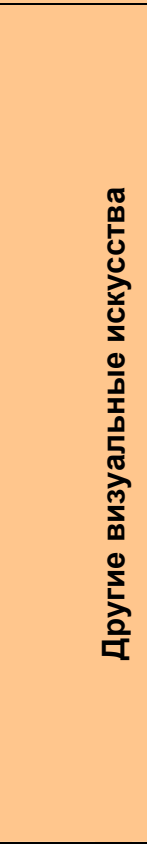 } & 970200 & & Оригинальные гравюры, графрика и литографиии & 89620 & $\begin{array}{l}\text { Оригинальные гравюры, графика и } \\
\text { литографрии }\end{array}$ \\
\hline & 970300 & & Оригинальные скульптуры и статуи из любого материала & 89630 & $\begin{array}{l}\text { Оригинальные скульптуры и статуи из } \\
\text { любого материала }\end{array}$ \\
\hline & 392640 & & Статуэтки и другие предметы украшения из пластмассы & $89399^{*}$ & $\begin{array}{l}\text { Статуэтки и другие предметы украшения из } \\
\text { пластмассы, не указанные в других } \\
\text { категориях }\end{array}$ \\
\hline & 442090 & & $\begin{array}{l}\text { Статуэтки и другие украшения из дерева } \\
\text { Деревянная инкрустация и мозаика; ларцы и шкатулки для ювелирных } \\
\text { изделий или столовых приборов и аналогичные изделия из дерева; } \\
\text { деревянная мебель }\end{array}$ & $63549^{*}$ & $\begin{array}{l}\text { Деревянная инкрустация и мозаика; ларцы и } \\
\text { шкатулки для ювелирных изделий или } \\
\text { столовых приборов и аналогичные изделия } \\
\text { из дерева; статуэтки и другие украшения, } \\
\text { деревянная мебель, не указанная в разделе } \\
82\end{array}$ \\
\hline & 691310 & & $\begin{array}{l}\text { Статуэтки и другие декоративные керамические изделия из фаянса или } \\
\text { фарфора }\end{array}$ & 66621 & $\begin{array}{l}\text { Статуэтки и другие декоративные } \\
\text { керамические изделия из фаянса или } \\
\text { фарфрора }\end{array}$ \\
\hline & 691390 & & $\begin{array}{l}\text { Статуэтки и другие декоративные керамические изделия, не указанные в } \\
\text { другом месте (за исключением фаянса или фарфора) }\end{array}$ & 66629 & $\begin{array}{l}\text { Другие статуэтки и другие декоративные } \\
\text { керамические изделия }\end{array}$ \\
\hline & 701890 & & Стеклянные изделия, включая статуэтки & $66593^{*}$ & $\begin{array}{l}\text { Стеклянные бусы, искусственный жемчуг, } \\
\text { искусственные драгоценные или полудрагоценные } \\
\text { камни и аналогичные небольшие стеклянные } \\
\text { предметы и изделия из них (кроме искусственных } \\
\text { ювелирных изделий); стеклянные глаза (не } \\
\text { являющиеся протезами); украшения и другие } \\
\text { декоративные изделия из маленьких шариков } \\
\text { лампового стекла, не превышающих в диаметре } 1 \\
\text { мм }\end{array}$ \\
\hline
\end{tabular}




\begin{tabular}{|c|c|c|c|c|}
\hline & 830621 & $\begin{array}{l}\text { Металлические статуэтки и другие украшения, отделанные драгоценным } \\
\text { металлом } \\
\text { Металлические статуэтки и другие украшения, отделанные драгоценным } \\
\text { металлом (за исключением произведений искусства, предметов } \\
\text { коллекционирования и антиквариата) }\end{array}$ & $69782^{*}$ & $\begin{array}{l}\text { Металлические статуэтки и другие } \\
\text { украшения; металлические рамки для } \\
\text { фотографрий, картин и других аналогичных } \\
\text { изделий; металлические зеркала }\end{array}$ \\
\hline & 960110 & $\begin{array}{l}\text { Обработанная слоновая кость и изделия из нее } \\
\text { Кость, черепаховый панцирь, рог, оленьи рога, кораллы, перламутр и другие } \\
\text { животные материалы для резьбы и изделия из этих материалов (включая } \\
\text { предметы, сделанные по отливкам) }\end{array}$ & $89911^{*}$ & $\begin{array}{l}\text { Обработанная слоновая кость, кость, } \\
\text { черепаховый панцирь, рог, оленьи рога, } \\
\text { кораллы, перламутр и другие животные } \\
\text { материалы для резьбы и изделия из этих } \\
\text { материалов (включая предметы, сделанные } \\
\text { по отливкам) }\end{array}$ \\
\hline \multirow{10}{*}{ 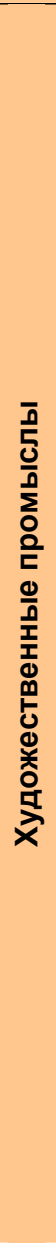 } & 580500 & $\begin{array}{l}\text { Ковровые изделия ручной работы типа гобеленов, фрамандских и } \\
\text { обюссонских гобеленов, гобеленов Бове и аналогичных расшитых вручную } \\
\text { изделий }\end{array}$ & 65891 & $\begin{array}{l}\text { Ковровые изделия ручной работы типа } \\
\text { гобеленов, фламандских и обюссонских } \\
\text { гобеленов, гобеленов Бове и аналогичных } \\
\text { расшитых вручную изделий (например, } \\
\text { крестиком и другими типами вышивки), } \\
\text { составных или нет }\end{array}$ \\
\hline & 580610 & $\begin{array}{l}\text { Узкие ткани: ткани с начесом (включая махровые и аналогичные ткани) и } \\
\text { ворсистые ткани }\end{array}$ & 65611 & $\begin{array}{l}\text { Ткани с начесом (включая махровые и } \\
\text { аналогичные ткани) и ворсистые ткани }\end{array}$ \\
\hline & 580620 & $\begin{array}{l}\text { Узкие ткани: другие ткани, содержащие по весу } 5 \% \text { или более эластичной } \\
\text { пряжи или резиновой нити }\end{array}$ & 65612 & $\begin{array}{l}\text { Другие ткани, содержащие по весу } 5 \% \text { или } \\
\text { более эластичной пряжи или резиновой нити }\end{array}$ \\
\hline & $\begin{array}{l}580631 \\
580632 \\
580639\end{array}$ & $\begin{array}{l}\text { Узкие ткани: другие хлопчатые ткани } \\
\text { Узкие ткани: другие ткани из волокон, сделанных людьми } \\
\text { Узкие ткани: другие ткани из других текстильных материалов }\end{array}$ & 65613 & Другие ткани \\
\hline & 580640 & Ткани безуточные, скрепленные склеиванием (болдюк) & 65614 & $\begin{array}{l}\text { Ткани безуточные, скрепленные } \\
\text { склеиванием (болдюк) }\end{array}$ \\
\hline & 580810 & $\begin{array}{l}\text { Тесьма в штуках; декоративная отделка в штуках без вышивки; за } \\
\text { исключением вязаной спицами или крючком } \\
\text { Другая тесьма в штуках; декоративная отделка в штуках без вышивки; за } \\
\text { исключением вязаной спицами или крючком }\end{array}$ & 65632 & $\begin{array}{l}\text { Tесьма в штуках; декоративная отделка в } \\
\text { штуках без вышивки, за исключением } \\
\text { вязаной спицами или крючком; кисти, } \\
\text { помпоны и аналогичные изделия }\end{array}$ \\
\hline & 580900 & $\begin{array}{l}\text { Ткани из металлической нити и ткани из металлизированной пряжи категории } \\
5605 \text { такого же типа, как используются для одежды в качестве отделки или для } \\
\text { аналогичных целей }\end{array}$ & 65491 & $\begin{array}{l}\text { Ткани из металлической нити и ткани из } \\
\text { металлизированной пряжи категории } 651.91 \\
\text { такого же типа, как используются для } \\
\text { одежды в качестве отделки или для } \\
\text { аналогичных целей, не указанные в других } \\
\text { местах }\end{array}$ \\
\hline & 581010 & Вышивка в штуках в полоску или без определенного мотива & 65651 & $\begin{array}{l}\text { Вышивка в штуках в полоску или без } \\
\text { определенного мотива }\end{array}$ \\
\hline & $\begin{array}{l}581091 \\
581092 \\
581099\end{array}$ & $\begin{array}{l}\text { Вышивка в штуках в полоску или с повторяющимся узором: другая вышивка } \\
\text { хлопчатыми нитками } \\
\text { Вышивка в штуках в полоску или с повторяющимся узором: другая вышивка } \\
\text { волокнами, сделанными человеком } \\
\text { Вышивка в штуках в полоску или с повторяющимся узором: другая вышивка } \\
\text { другими текстильными материалами }\end{array}$ & 65659 & $\begin{array}{l}\text { Другая вышивка в штуках в полоску или с } \\
\text { повторяющимся узором }\end{array}$ \\
\hline & 581100 & Стеганые текстильные продукты в штуках & 65740 & $\begin{array}{l}\text { Стеганые текстильные продукты в штуках, } \\
\text { состоящие из одного или более слоев } \\
\text { текстильных материалов, скрепленных с } \\
\text { набивкой сшиванием или другим способом, } \\
\text { не указанные в других местах }\end{array}$ \\
\hline
\end{tabular}




\begin{tabular}{|c|c|c|c|c|}
\hline & $\begin{array}{l}600240 \\
600290 \\
600310 \\
600320 \\
600330 \\
600340 \\
600390\end{array}$ & $\begin{array}{l}\text { Вязаные спицами или крючком ткани, ширина которых не превышает } 30 \text { см, } \\
\text { содержащие по весу 5\% или более эластичной пряжи, но не имеющие резиновой } \\
\text { нити } \\
\text { Другие вязаные спицами или крючком ткани, ширина которых не превышает } 30 \\
\text { см, содержащие по весу } 5 \% \text { или более эластичной пряжи или резиновой нити } \\
\text { Вязаные спицами или крючком ткани, ширина которых не превышает } 30 \text { см из } \\
\text { шерсти и пуха животных } \\
\text { Вязаные спицами или крючком ткани, ширина которых не превышает } 30 \text { см из } \\
\text { хлопка } \\
\text { Вязаные спицами или крючком ткани, ширина которых не превышает } 30 \text { см из } \\
\text { синтетического волокна } \\
\text { Вязаные спицами или крючком ткани, ширина которых не превышает } 30 \text { см из } \\
\text { искусственного волокна } \\
\text { Другие вязаные спицами или крючком ткани, ширина которых не превышает } 30 \text { см }\end{array}$ & 65521 & $\begin{array}{l}\text { Другие вязаные спицами или крючком ткани } \\
\text { без пропитки, покрытия, оплетки или } \\
\text { расщепления, ширина которых не } \\
\text { превышает } 30 \text { см }\end{array}$ \\
\hline & 600410 & $\begin{array}{l}\text { Вязаные спицами или крючком ткани, ширина которых превышает } 30 \text { см, } \\
\text { содержащие по весу } 5 \% \text { или более эластичной пряжи, но не имеющие резиновой } \\
\text { нити } \\
\text { Другие вязаные спицами или крючком ткани, ширина которых превышает } 30 \text { см, } \\
\text { содержащие по весу } 5 \% \text { или более эластичной пряжи или резиновой нити }\end{array}$ & 65522 & $\begin{array}{l}\text { Другие вязаные спицами или крючком ткани } \\
\text { без пропитки, покрытия, оплетки или } \\
\text { расщепления, ширина которых превышает } \\
30 \text { см, содержащие по весу 5\% или более } \\
\text { эластичной пряжи или резиновой нити }\end{array}$ \\
\hline \multirow{3}{*}{ 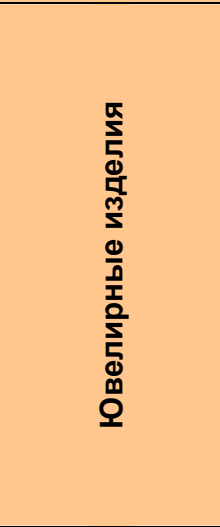 } & $\begin{array}{l}711311 \\
711319 \\
711320\end{array}$ & $\begin{array}{l}\text { Ювелирные изделия и их части из серебра, с покрытием или без покрытия другим } \\
\text { благородным металлом } \\
\text { Ювелирные изделия и их части из других благородных металлов, с покрытием } \\
\text { или без покрытия другим благородным металлом } \\
\text { Ювелирные изделия и их части из обычного металла с покрытием благородным } \\
\text { металлом }\end{array}$ & 89731 & $\begin{array}{l}\text { Ювелирные изделия и их части из } \\
\text { благородных металлов с покрытием другим } \\
\text { благородным металлом (за исключением } \\
\text { часов и корпусов для часов) }\end{array}$ \\
\hline & $\begin{array}{l}711411 \\
711419 \\
711420\end{array}$ & $\begin{array}{l}\text { Изделия ювелиров и их части из серебра, с покрытием или без покрытия другим } \\
\text { благородным металлом } \\
\text { Изделия ювелиров и их части из других благородных металлов, с покрытием или } \\
\text { без покрытия благородным металлом } \\
\text { Изделия ювелиров и их части из обычного металла с покрытием благородным } \\
\text { металлом }\end{array}$ & 89732 & $\begin{array}{l}\text { Изделия ювелиров и их части из } \\
\text { благородного металла или с покрытием } \\
\text { благородным металлом (отличные от } \\
\text { товаров категории 897.31) }\end{array}$ \\
\hline & 711610 & $\begin{array}{l}\text { Изделия из естественного и искусственно выращенного жемчуга } \\
\text { Изделия из драгоценных или полудрагоценных камней (натуральных, } \\
\text { синтетических или искусственных) }\end{array}$ & 89733 & $\begin{array}{l}\text { Изделия из естественного и искусственно } \\
\text { выращенного жемчуга или из драгоценных } \\
\text { или полудрагоценных камней (натуральных, } \\
\text { синтетических или искусственных) }\end{array}$ \\
\hline Фотография & $\begin{array}{l}370510 \\
370590\end{array}$ & $\begin{array}{l}\text { Фотографические пластины и пленка, экспонированная и проявленная, за } \\
\text { исключением кинопленки для офсетной печати } \\
\text { Фотографические пластины и пленка, экспонированная и проявленная (за } \\
\text { исключением предназначенной для офсетной печати) }\end{array}$ & $88260^{*}$ & $\begin{array}{l}\text { Фотографические пластины и пленка, } \\
\text { экспонированная и проявленная, за } \\
\text { исключением кинопленки }\end{array}$ \\
\hline \multicolumn{5}{|c|}{ Г. Книги и пресса } \\
\hline \multirow{3}{*}{ 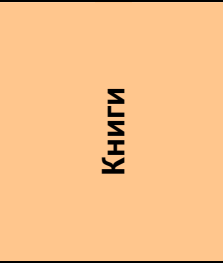 } & 490110 & $\begin{array}{l}\text { Печатные книги, брошюры, листовки и другие печатные издания либо } \\
\text { отдельными листами, либо сфральцованные или нет }\end{array}$ & 89215 & $\begin{array}{l}\text { Печатные книги, брошюры, листовки и } \\
\text { другие печатные издания либо отдельными } \\
\text { листами, либо сфральцованные или нет }\end{array}$ \\
\hline & 490191 & Словари и энциклопедии и их серийные выпуски & 89216 & $\begin{array}{l}\text { Словари и энциклопедии не отдельными } \\
\text { листами }\end{array}$ \\
\hline & 490199 & Печатные книги, брошюры и аналогичная печатная продукция & 89219 & $\begin{array}{l}\text { Другие печатные книги, брошюры и } \\
\text { аналогичная печатная продукция, исключая } \\
\text { отдельные листы }\end{array}$ \\
\hline
\end{tabular}




\begin{tabular}{|c|c|c|c|c|}
\hline \multirow{2}{*}{ 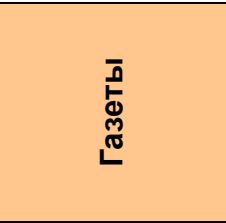 } & 490210 & $\begin{array}{l}\text { Газеты, журналы и периодические издания, иллюстрированные или нет, или } \\
\text { содержащие рекламные материалы, выходящие не менее четырех раз в неделю }\end{array}$ & 89221 & $\begin{array}{l}\text { Газеты, журналы и периодические издания, } \\
\text { иллюстрированные или нет, или содержащие } \\
\text { рекламные материалы, выходящие не менее } \\
\text { четырех раз в неделю }\end{array}$ \\
\hline & 490290 & Другие газеты, журналы и периодические издания & 89229 & $\begin{array}{l}\text { Другие газеты, журналы и периодические } \\
\text { издания, иллюстрированные или нет, или } \\
\text { содержащие рекламные материалы }\end{array}$ \\
\hline \multirow{5}{*}{ 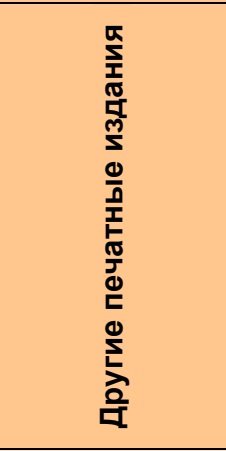 } & 490300 & Детские картинки, рисунки или книжки-раскраски & 89212 & $\begin{array}{l}\text { Детские картинки, рисунки или книжки- } \\
\text { раскраски }\end{array}$ \\
\hline & 490591 & Карты и гидрографические или аналогичные схемы всех типов в форме книг & 89213 & Карты и схемы в форме книг \\
\hline & $\begin{array}{l}490510 \\
490599\end{array}$ & $\begin{array}{l}\text { Карты и гидрографические или аналогичные схемы всех типов в форме глобусов } \\
\text { Другие карты и гидрографические или аналогичные схемы всех типов }\end{array}$ & 89214 & $\begin{array}{l}\text { Карты и гидрографические или аналогичные } \\
\text { схемы всех типов (включая настенные } \\
\text { карты, топографические планы и глобусы), } \\
\text { напечатанные не в книжной фрорме }\end{array}$ \\
\hline & 490900 & $\begin{array}{l}\text { Почтовые открытки, печатные или иллюстрированные; печатные } \\
\text { поздравительные открытки }\end{array}$ & 89242 & $\begin{array}{l}\text { Печатные или иллюстрированные почтовые } \\
\text { открытки; печатные открытки с приветствиями } \\
\text { личного характера, сообщениями или } \\
\text { заявлениями, иллюстрированные или нет, с } \\
\text { конвертами и образами или без них }\end{array}$ \\
\hline & 491000 & Любые печатные календари, включая календарные блоки & 89284 & $\begin{array}{l}\text { Любые печатные календари (включая } \\
\text { календарные блоки) }\end{array}$ \\
\hline \multicolumn{5}{|c|}{ Д. Аудиовизуальные и интерактивные средства } \\
\hline \multirow{3}{*}{ 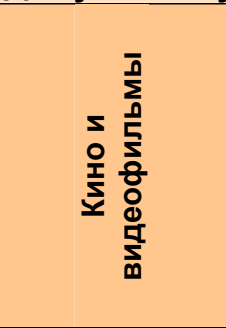 } & 370610 & $\begin{array}{l}\text { Кинофильмы, экспонированные и проявленные, включающие звуковую дорожку } \\
\text { или нет, или состоящие только из звуковой дорожки, шириной } 35 \text { мм или более }\end{array}$ & 88310 & $\begin{array}{l}\text { Кинофильмы, экспонированные и } \\
\text { проявленные, включающие звуковую } \\
\text { дорожку или нет, или состоящие только из } \\
\text { звуковой дорожки, шириной } 35 \text { мм или более }\end{array}$ \\
\hline & 370690 & $\begin{array}{l}\text { Кинофильмы, экспонированные и проявленные, включающие звуковую дорожку } \\
\text { или нет, или состоящие только из звуковой дорожки, ширина < } 35 \text { мм }\end{array}$ & 88390 & $\begin{array}{l}\text { Другие кинофильмы, экспонированные и } \\
\text { проявленные, включающие звуковую } \\
\text { дорожку или нет, или состоящие только из } \\
\text { звуковой дорожки }\end{array}$ \\
\hline & 950410 & Видеоигры, используемые с телевизионным приемником & 89431 & $\begin{array}{l}\text { Видеоигры, используемые с телевизионным } \\
\text { приемником }\end{array}$ \\
\hline \multicolumn{5}{|c|}{ Е. Дизайн и творческие услуги } \\
\hline $\begin{array}{l}\text { Архитектура } \\
\text { и дизайн }\end{array}$ & 490600 & $\begin{array}{l}\text { Планы и чертежи, имеющие архитектурные, инженерные, промышленные, } \\
\text { коммерческие, топографические или аналогичные цели, являющиеся сделанными } \\
\text { от руки оригиналами; рукописные тексты; фотографические воспроизведения на } \\
\text { очувствлённой бумаге или сделанные под копирку копии вышеупомянутого }\end{array}$ & $89282^{*}$ & $\begin{array}{l}\text { Планы и чертежи, имеющие архитектурные, } \\
\text { инженерные, промышленные, коммерческие, } \\
\text { топографические или аналогичные цели, } \\
\text { являющиеся сделанными от руки оригиналами; } \\
\text { рукописные тексты; фотографические } \\
\text { воспроизведения на очувствлённой бумаге или } \\
\text { сделанные под копирку копии вышеупомянутого }\end{array}$ \\
\hline \multicolumn{5}{|c|}{ СОПУТСТВУЮЩИЕ КУЛЬТУРНЫЕ ТОВАРЫ } \\
\hline \multicolumn{5}{|l|}{ Ж. Туризм ${ }^{3}$} \\
\hline \multicolumn{5}{|c|}{ 3. Спорт и досуг ${ }^{4}$} \\
\hline
\end{tabular}

\section{Примечания:}

1 Включает записанные и незаписанные носители. Некоторые следует исключить, в то время как другие следует отнести к расширенной категории.

2 Из этой категории следует исключить дизайн и включить в категорию $\mathrm{E}-$ Дизайн и творческие услуги.

3 Культурные товары, приобретенные туристами, уже включены в соответствующие области от А до $\mathrm{E}$.

Не охватывает спорт и товары для проведения досуга. Культурные обычаи рассматриваются как относящиеся к культуре. Все товары для спорта и досуга рассматриваются как материалы и оборудование. 


\begin{tabular}{|c|c|c|c|c|c|}
\hline \multicolumn{6}{|c|}{ ОБОРУДОВАНИЕ И СОПУТСТВУЮЩИЕ МАТЕРИАЛЫ КУЛЬТУРНЫХ ТОВАРОВ } \\
\hline \multicolumn{6}{|c|}{ Б. Представления и празднества } \\
\hline \multirow{3}{*}{ 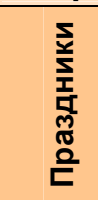 } & 950510 & & Предметы для рождественских праздников & 89445 & Другие предметы для рождественских праздников \\
\hline & 950590 & & $\begin{array}{l}\text { Предметы для фестивалей, карнавалов или других } \\
\text { развлечений, включая фокусы и клоунаду, не указанные в } \\
\text { другом месте }\end{array}$ & 89449 & Другие предметы для развлечений \\
\hline & 950810 & 5 & Бродячие цирки и зверинцы & $89460^{*}$ & $\begin{array}{l}\text { Карусели, качели, тиры и другие аттракционы, бродячие цирки, } \\
\text { зверинцы и театры }\end{array}$ \\
\hline \multirow{10}{*}{ 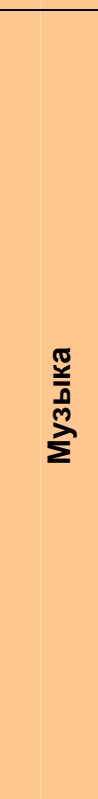 } & 851920 & & $\begin{array}{l}\text { Музыкальные аппараты, приводимые в действие монетами, } \\
\text { банкнотами, банковскими карточками, жетонами или другими } \\
\text { платежными средствами }\end{array}$ & 76331 & $\begin{array}{l}\text { Аппараты, приводимые в действие монетами, банкнотами, } \\
\text { банковскими карточками, жетонами или другими платежными } \\
\text { средствами }\end{array}$ \\
\hline & 851930 & & Проигрыватели (электропроигрыватели) & 76335 & Проигрыватели (электропроигрыватели) \\
\hline & 851810 & & Микрофоны и подставки для них & 76421 & Микрофооны и подставки для них \\
\hline & $\begin{array}{l}851821 \\
851822\end{array}$ & & $\begin{array}{l}\text { Одиночные динамики, вмонтированные в корпуса } \\
\text { Несколько динамиков, вмонтированных в один корпус }\end{array}$ & 76422 & Динамики, вмонтированные в корпуса \\
\hline & 851829 & & Другие микрофоны и подставки для них & 76423 & Динамики, не вмонтированные в корпуса \\
\hline & 851830 & & $\begin{array}{l}\text { Наушники, соединенные или несоединенные с микрофонами, } \\
\text { и системы, состоящие из микрофона и одного или более } \\
\text { динамиков }\end{array}$ & 76424 & Наушники и системы, состоящие из микрофона/динамика \\
\hline & 851840 & & Электрические усилители звуковых сигналов & 76425 & Электрические усилители звуковых сигналов \\
\hline & 851850 & & Системы звуковых электрических усилителей & 76426 & Системы звуковых электрических усилителей \\
\hline & $\begin{array}{l}920930 \\
920991\end{array}$ & & $\begin{array}{l}\text { Струны для музыкальных инструментов } \\
\text { Части и принадлежности для пианино }\end{array}$ & & \\
\hline & $\begin{array}{l}920992 \\
920994\end{array}$ & & $\begin{array}{l}\text { Части и принадлежности для музыкальных инструментов } \\
\text { категории } 9202 \\
\text { Части и принадлежности для музыкальных инструментов } \\
\text { категории } 9207 \\
\text { Части и принадлежности для музыкальных инструментов, } \\
\text { «например, механизмы для музыкальных шкатулок, карты, } \\
\text { диски и валики для механических инструментов», не } \\
\text { классифицированные в других рубриках; метрономы, } \\
\text { камертоны и другие инструменты для настройки всех типов }\end{array}$ & 89890 & $\begin{array}{l}\text { Части и принадлежности для музыкальных инструментов (например, } \\
\text { механизмы для музыкальных шкатулок, перфокарты, диски и валики } \\
\text { для механических инструментов); метрономы, камертоны и другие } \\
\text { инструменты для настройки всех типов }\end{array}$ \\
\hline \multicolumn{6}{|c|}{ В. Визуальные искусства и художественные промыслы } \\
\hline 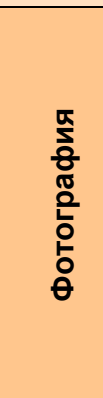 & $\begin{array}{l}370120 \\
370130\end{array}$ & 6 & $\begin{array}{l}\text { Пленка для оперативной полиграфии } \\
\text { Другие пластинки и пленка, по любому краю превышающие } \\
255 \text { мм } \\
\text { Фотографические пластинки и пленка для плоской печати, } \\
\text { чувствительные, неэкспонированные для цветной } \\
\text { фотографии } \\
\text { Фотографические пластинки и пленка для плоской печати } \\
\text { монохромной фотографии, чувствительные, } \\
\text { неэкспонированные из любого материала, кроме бумаги, } \\
\text { картона или тканей (за исключением рентгеновской пленки и } \\
\text { фотографрических пластинок, пленок для плоской печати по } \\
\text { любому краю > } 255 \text { мм и пленки для оперативной полиграфии }\end{array}$ & $88220^{*}$ & $\begin{array}{l}\text { Фотографрические пластинки и пленка для плоской печати, } \\
\text { чувствительные, неэкспонированные из любого материала, кроме } \\
\text { бумаги, картона или тканей; пленка для оперативной полиграфии для } \\
\text { плоской печати, чувствительная, неэкспонированная, в упаковке или } \\
\text { без нее }\end{array}$ \\
\hline
\end{tabular}




\begin{tabular}{|c|c|c|c|c|c|}
\hline & 3702 & 7 & $\begin{array}{l}\text { Фотографическая пленка в роликах, чувствительная, } \\
\text { неэкспонированная, из любого материала, кроме бумаги, } \\
\text { картона или ткани }\end{array}$ & $88230^{*}$ & $\begin{array}{l}\text { Фотографическая пленка в роликах, чувствительная, } \\
\text { неэкспонированная, из любого материала, кроме бумаги, картона или } \\
\text { ткани; пленка для оперативной полиграфии в роликах, } \\
\text { чувствительная, неэкспонированная }\end{array}$ \\
\hline & 3703 & 8 & $\begin{array}{l}\text { Фотографическая бумага, картон и ткани, чувствительные, } \\
\text { неэкспонированные }\end{array}$ & $88240^{*}$ & $\begin{array}{l}\text { Фотографрическая бумага, картон и ткани, чувствительные, } \\
\text { неэкспонированные }\end{array}$ \\
\hline & 370400 & & $\begin{array}{l}\text { Фотографическая бумага, картон и ткани, экспонированные, } \\
\text { но не проявленные }\end{array}$ & 88250 & $\begin{array}{l}\text { Фотографрическая бумага, картон и ткани, чувствительные, } \\
\text { экспонированные, но не проявленные }\end{array}$ \\
\hline & $\begin{array}{l}370710 \\
370790\end{array}$ & & $\begin{array}{l}\text { Эмульсионные препараты, придающие чувствительность } \\
\text { Другие химические препараты, используемые в фотографии }\end{array}$ & 88210 & $\begin{array}{l}\text { Химические препараты, используемые в фотографии (за } \\
\text { исключением лаков, клеев, связывающих материалов и аналогичных } \\
\text { препаратов); несмешанные препараты для применения в фотографии } \\
\text { в соразмерных пропорциях \или продающиеся в рознице в готовом } \\
\text { виде }\end{array}$ \\
\hline & 9006 & 9 & $\begin{array}{l}\text { Фотокамеры (за исключением кинокамер), принадлежности к } \\
\text { ним }\end{array}$ & $8811^{*}$ & $\begin{array}{l}\text { Фотокамеры (кроме кинокамер); аппараты для вспышек и лампы для } \\
\text { вспышек (кроме разрядных ламп в подгруппе } 778.2) ; \text { их части и } \\
\text { принадлежности к ним }\end{array}$ \\
\hline & $\begin{array}{l}901010 \\
901050 \\
901060\end{array}$ & & $\begin{array}{l}\text { Устройства и оборудование для автоматического проявления } \\
\text { фотопленки (включая кинопленку) или бумаги в роликах, или } \\
\text { для автоматического экспонирования проявленной пленки в } \\
\text { роликах или фотобумаге } \\
\text { Другие устройства и оборудование для фотолабораторий } \\
\text { (включая кинематографические); негатоскопы } \\
\text { Проекционные экраны }\end{array}$ & 88135 & $\begin{array}{l}\text { Устройства и оборудование для фотолабораторий (включая } \\
\text { кинематографрические) (включая устройства для проекции печатных } \\
\text { схем на чувствительных полупроводниковых материалах), не } \\
\text { указанные в другом месте; негатоскопы; проекционные экраны }\end{array}$ \\
\hline & 901090 & & $\begin{array}{l}\text { Части и принадлежности для устройств и оборудования } \\
\text { фотолабораторий }\end{array}$ & 88136 & $\begin{array}{l}\text { Части и принадлежности для устройств и оборудования раздела } \\
881.35\end{array}$ \\
\hline Г. Кни & ecc & & & & \\
\hline & $\begin{array}{l}844314 \\
844315\end{array}$ & & $\begin{array}{l}\text { Оборудование для высокой печати с рулонной подачей, за } \\
\text { исключением флексографической печати } \\
\text { Оборудование для высокой печати без рулонной подачи, за } \\
\text { исключением фрлексографической печати }\end{array}$ & 72661 & Оборудование для высокой печати \\
\hline & 834316 & & Оборудование для флексографической печати & 72663 & Оборудование для фрлексографической печати \\
\hline & 834317 & & Оборудование для печати гравюр & 72665 & Оборудование для печати гравюр \\
\hline Д. Ауд & зизуаль & & е и интерактивные средства & & \\
\hline & 852110 & & $\begin{array}{l}\text { Устройства для видеозаписи и воспроизведения с магнитной } \\
\text { пленкой }\end{array}$ & 76381 & $\begin{array}{l}\text { Видеозаписывающие или воспроизводящие устройства с } \\
\text { видеотюнером или без видеотюнера с магнитной пленкой }\end{array}$ \\
\hline 疍 & 852190 & & $\begin{array}{l}\text { Устройства для видеозаписи и воспроизведения с } \\
\text { видеотюнером или без него (за исключением устройств с } \\
\text { магнитной пленкой и устройств записи на видеокамерах) }\end{array}$ & 76384 & $\begin{array}{l}\text { Другие видеозаписывающие или воспроизводящие устройства с } \\
\text { видеотюнером или без видеотюнера }\end{array}$ \\
\hline m ฏ & 852550 & & Передатчики & 76431 & Передатчики \\
\hline 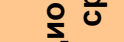 & 852560 & & Передатчики с приемниками & 76432 & Передатчики с приемниками \\
\hline 宾 & 852580 & & $\begin{array}{l}\text { Записывающие устройства телекамер, цифровых камеры и } \\
\text { видеокамер }\end{array}$ & 76484 & $\begin{array}{l}\text { Записывающие устройства телекамер, цифровых камеры и } \\
\text { видеокамер }\end{array}$ \\
\hline
\end{tabular}




\begin{tabular}{|c|c|c|c|c|}
\hline \multirow{7}{*}{ 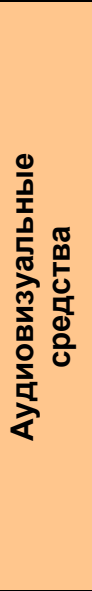 } & 8527 & $\begin{array}{l}\text { Радиоприемники, совмещенные в одном корпусе или нет со } \\
\text { звукозаписывающими или воспроизводящими устройствами, } \\
\text { или часами }\end{array}$ & 762 & $\begin{array}{l}\text { Радиоприемники, совмещенные в одном корпусе или нет со } \\
\text { звукозаписывающими или воспроизводящими устройствами, или } \\
\text { часами }\end{array}$ \\
\hline & 8528 & $\begin{array}{l}\text { Мониторы, проекторы, не включающие телевизионные } \\
\text { приемники; телевизионные приемники, совмещенные или нет с } \\
\text { радиоприемниками или звукозаписывающими } \\
\text { воспроизводящими устройствами }\end{array}$ & 761 & $\begin{array}{l}\text { Телевизионные приемники; устройства для приема телевизионных } \\
\text { передач, совмещенные или нет с радиоприемниками или аудио- или } \\
\text { видеозаписывающими или воспроизводящими устройствами }\end{array}$ \\
\hline & 9007 & $\begin{array}{l}\text { Кинокамеры и проекторы, совмещенные или нет со } \\
\text { звукозаписывающими или воспроизводящими устройствами }\end{array}$ & 8812 & $\begin{array}{l}\text { Кинокамеры и проекторы, совмещенные или нет со } \\
\text { звукозаписывающими или воспроизводящими устройствами; их части } \\
\text { и принадлежности }\end{array}$ \\
\hline & 900820 & $\begin{array}{l}\text { Микрофильмы, микрофиши или другие миниатюрные } \\
\text { устройства для чтения, которые могут или не могут делать } \\
\text { копии }\end{array}$ & 88131 & $\begin{array}{l}\text { Микрофрильмы, микрофиши или другие миниатюрные устройства для } \\
\text { чтения, которые могут или не могут делать копии }\end{array}$ \\
\hline & $\begin{array}{l}900810 \\
900830 \\
\end{array}$ & $\begin{array}{l}\text { Проекционные аппараты } \\
\text { Другие проекционные аппараты }\end{array}$ & 88132 & Проекционные аппараты, не указанные в другом месте \\
\hline & 900840 & Фотоувеличители (кроме кинематографических) & 88133 & Фотоувеличители (кроме кинематографических) \\
\hline & 900890 & $\begin{array}{l}\text { Части и принадлежности проекционных аппаратов, категория } \\
9008\end{array}$ & 88134 & Части и принадлежности оборудования категорий 881.31 - 881.33 \\
\hline \multirow{6}{*}{ 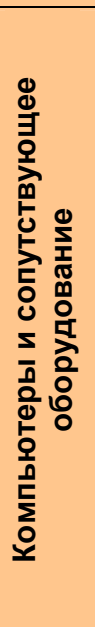 } & 847130 & $\begin{array}{l}\text { Портативные устройства для автоматической обработки } \\
\text { данных }\end{array}$ & 75220 & $\begin{array}{l}\text { Портативные устройства для автоматической обработки данных } \\
\text { весом не более } 10 \text { кг, состоящие, по крайней мере, из центрального } \\
\text { процессора, клавиатуры и дисплея }\end{array}$ \\
\hline & $\begin{array}{l}847141 \\
847149 \\
847150\end{array}$ & $\begin{array}{l}\text { Другие устройства для автоматической обработки данных, } \\
\text { объединяющие в одном корпусе, по крайней мере, } \\
\text { центральный процессор, входное и выходное устройства } \\
\text { Другие устройства для автоматической обработки данных, } \\
\text { представленные в фрорме систем } \\
\text { Процессоры, отличные от указанных в подкатегориях } 847141 \\
\text { или } 847149, \text { имеющие в одном корпусе или нет следующие } \\
\text { типы устройств: блоки памяти, входное и выходное устройства }\end{array}$ & 75230 & Другие устройства для автоматической обработки данных \\
\hline & 847160 & $\begin{array}{l}\text { Входное или выходное устройства, имеющие в одном корпусе } \\
\text { или нет блок памяти }\end{array}$ & 75260 & $\begin{array}{l}\text { Входное или выходное устройства, имеющие в одном корпусе или нет } \\
\text { блок памяти }\end{array}$ \\
\hline & 847170 & Блоки памяти & 75270 & Блоки памяти \\
\hline & 847180 & $\begin{array}{l}\text { Другое оборудование устройств для автоматической обработки } \\
\text { данных }\end{array}$ & 75280 & $\begin{array}{l}\text { Другое оборудование устройств для автоматической обработки } \\
\text { данных }\end{array}$ \\
\hline & 847330 & Части и принадлежности устройств категории 8471 & 75997 & $\begin{array}{l}\text { Части и принадлежности (за исключением корпусов, сумок для } \\
\text { переноски и т.п.) используемые исключительно или преимущественно } \\
\text { с устройствами группы } 752 \text {. }\end{array}$ \\
\hline
\end{tabular}

\section{Примечания:}

5 Включает только бродячие цирки и зверинцы (исключает категорию 950890).

6 Исключает фоотографические пластинки и рентгеновские пленки (категория 370110).

7 Исключает фотопленку в роликах для рентгеновских снимков (категория 370210).

8 Включает только фотографию.

9 Исключает камеры специального назначения, например, камеры для медицинских обследований (категория 900630). 


\begin{tabular}{|c|c|c|c|c|c|}
\hline \multicolumn{6}{|c|}{ Ж. Туризм } \\
\hline & 890110 & & Круизные суда & 79328 & $\begin{array}{l}\text { Круизные суда, экскурсионные катера и аналогичные суда, } \\
\text { предназначенные в основном для перевозки людей; все } \\
\text { типы паромов }\end{array}$ \\
\hline \multicolumn{6}{|c|}{ 3. Спорт и досуг } \\
\hline \multirow{7}{*}{$\begin{array}{l}\text { 응 } \\
\text { ㄷํㄴ }\end{array}$} & $\begin{array}{l}950611 \\
950612 \\
950619\end{array}$ & & $\begin{array}{l}\text { Лыжи } \\
\text { Лыжные крепления } \\
\text { Лыжное оборудование для занятий зимним спортом (за } \\
\text { исключением лыжных креплений) }\end{array}$ & 89473 & Лыжи и другое лыжное оборудование \\
\hline & $\begin{array}{l}950621 \\
950629\end{array}$ & & $\begin{array}{l}\text { Виндсерферы } \\
\text { Водные лыжи, доски для серфинга и другое оборудование для } \\
\text { водных видов спорта (за исключением виндсерферов) }\end{array}$ & 89474 & $\begin{array}{l}\text { Водные лыжи, доски для серфинга, виндсерферы и другое } \\
\text { оборудование для водных видов спорта }\end{array}$ \\
\hline & $\begin{array}{l}950631 \\
950632 \\
950639\end{array}$ & & $\begin{array}{l}\text { Клюшки } \\
\text { Мячи } \\
\text { Оборудование для гольфа (за исключением мячей и комплектов } \\
\text { клюшек) }\end{array}$ & 89475 & Оборудование для гольфа \\
\hline & $\begin{array}{l}950640 \\
950661 \\
950662 \\
950669 \\
950699\end{array}$ & & $\begin{array}{l}\text { Предметы и оборудование для настольного тенниса } \\
\text { Теннисные мячи } \\
\text { Надувные мячи } \\
\text { Другие мячи (отличные от мячей для гольфа и теннисных мячей) } \\
\text { Другие предметы и оборудование для общих фризических } \\
\text { упражнений }\end{array}$ & 89479 & Спортивные товары, не указанные в другом месте \\
\hline & $\begin{array}{l}950651 \\
950659\end{array}$ & & $\begin{array}{l}\text { Ракетки для тенниса } \\
\text { Ракетки для бадминтона и аналогичных игр со струнами или без } \\
\text { них (за исключением ракеток для тенниса и настольного тенниса) }\end{array}$ & 89476 & $\begin{array}{l}\text { Ракетки для тенниса, бадминтона и аналогичных игр, со } \\
\text { струнами или без них }\end{array}$ \\
\hline & 950670 & & Коньки и роликовые коньки & 89472 & $\begin{array}{l}\text { Коньки и роликовые коньки (включая коньки и роликовые } \\
\text { коньки с ботинками) }\end{array}$ \\
\hline & 950691 & & Предметы и оборудование для общих физических упражнений & 89478 & $\begin{array}{l}\text { Предметы и оборудование для общих физических } \\
\text { упражнений, гимнастики или легкой атлетики }\end{array}$ \\
\hline \multirow{4}{*}{ 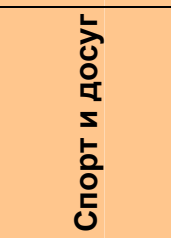 } & 890310 & & Надувные суда для развлечения или занятий спортом & 79311 & Надувные суда (включая гребные лодки и каноэ) \\
\hline & 890391 & & Парусные лодки & 79312 & $\begin{array}{l}\text { Парусные лодки не надувные с дополнительным } \\
\text { двигателем или без него }\end{array}$ \\
\hline & $\begin{array}{l}890392 \\
890399\end{array}$ & & $\begin{array}{l}\text { Моторные лодки } \\
\text { Другие яхты }\end{array}$ & 79319 & $\begin{array}{l}\text { Ненадувные гребные лодки, каноэ и суда для развлечения } \\
\text { или занятий спортом, не указанные в другом месте }\end{array}$ \\
\hline & 950890 & 10 & $\begin{array}{l}\text { Качели, карусели, тиры и другие аттракционы; передвижные } \\
\text { театры }\end{array}$ & 89460 & $\begin{array}{l}\text { Качели, карусели, тиры и другие аттракционы, бродячие } \\
\text { цирки и зверинцы и передвижные театры }\end{array}$ \\
\hline $\begin{array}{l}\text { Азартные } \\
\text { игры }\end{array}$ & 950490 & & $\begin{array}{l}\text { Столы для игр в казино, оборудование для автоматического } \\
\text { боулинга и других развлекательных игр, настольные или } \\
\text { комнатные игры, включая столы для настольных игр (исключая } \\
\text { игры, действующие при опускании монет, банкнот «бумажной } \\
\text { валюты», жетонов или других аналогичных предметов, бильярд, } \\
\text { видеоигры с использованием телевизионных приемников и } \\
\text { игральные карты) }\end{array}$ & 89439 & $\begin{array}{l}\text { Предметы для развлекательных игр, столы для комнатных } \\
\text { игр, не указанные в другом месте }\end{array}$ \\
\hline
\end{tabular}

\section{Примечания:}

10 Исключая бродячие цирки и зверинцы (9508.10). 
Таблица 4. Профессии в области культуры в определении категорий МСКЗ 08

\begin{tabular}{|c|c|c|c|c|}
\hline \multicolumn{5}{|c|}{ ПРОФЕССИИ В ОБЛАСТИ КУЛЬТУРЫ } \\
\hline Область & Функция & МСКЗ 08 & & Описание \\
\hline \multirow{4}{*}{$\begin{array}{l}\text { А. Культурное и } \\
\text { природное } \\
\text { наследие }\end{array}$} & Создание & 2632 & 1 & Социологи, антропологи и смежные профессии \\
\hline & Распространение & 3433 & & Технические сотрудники галерей, библиотек и музеев \\
\hline & Демонстрация/восприятие & 1349 & 2 & $\begin{array}{l}\text { Управляющие, оказывающие профессиональные услуги, не классифицированные в других } \\
\text { рубриках }\end{array}$ \\
\hline & Архивирование/хранение & $\begin{array}{l}2133 \\
2621\end{array}$ & $\begin{array}{l}3 \\
4 \\
\end{array}$ & $\begin{array}{l}\text { Специалисты в области охраны окружающей среды } \\
\text { Архивариусы и смотрители }\end{array}$ \\
\hline \multirow{3}{*}{$\begin{array}{l}\text { Б. } \\
\text { Представления } \\
\text { и празднества }\end{array}$} & Создание & 2659 & 5 & Творческие деятели культуры и артисты, не классифицированные в других рубриках \\
\hline & Производство & $\begin{array}{l}2652 \\
2653 \\
7312\end{array}$ & & $\begin{array}{l}\text { Музыканты, певцы и композиторы } \\
\text { Танцоры и хореографы } \\
\text { Производители музыкальных инструментов и настройщики }\end{array}$ \\
\hline & $\begin{array}{l}\text { Образование/подготовка } \\
\text { кадров }\end{array}$ & $\begin{array}{l}2310 \\
2320 \\
2354\end{array}$ & $\begin{array}{l}6 \\
6\end{array}$ & $\begin{array}{l}\text { Преподаватели университетов и других высших учебных заведений } \\
\text { Преподаватели учебных заведений профессионального образования } \\
\text { Другие преподаватели музыки }\end{array}$ \\
\hline \multirow{3}{*}{ 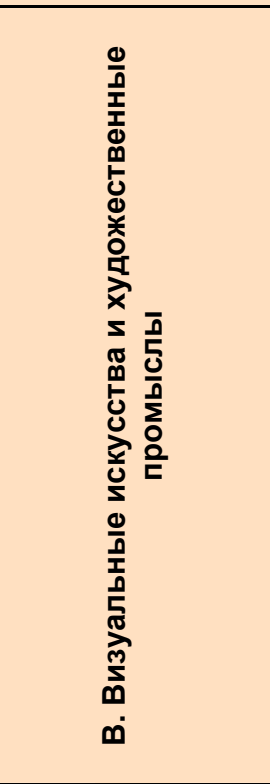 } & Создание & $\begin{array}{l}2651 \\
3118\end{array}$ & & $\begin{array}{l}\text { Художники визуальных видов искусства } \\
\text { Чертежники }\end{array}$ \\
\hline & Производство & $\begin{array}{l}3431 \\
7313 \\
7314 \\
7315 \\
7316 \\
7317 \\
7318 \\
7319 \\
7522 \\
7531 \\
7532 \\
7533 \\
7534 \\
7535 \\
7536 \\
7549\end{array}$ & & $\begin{array}{l}\text { Фотографы } \\
\text { Ювелиры и мастера по драгоценным камням } \\
\text { Гончары и схожие профессии } \\
\text { Стеклодувы, резчики, шлифовальщики и отделочники } \\
\text { Художники по рекламе, художники-декораторы, граверы и офортисты } \\
\text { Резчики по дереву, корзинщики, мастера по работе со схожими материалами } \\
\text { Ткачи, кожевники, мастера по работе со схожими материалами } \\
\text { Мастера, работающие вручную, не классифицированные в других рубриках } \\
\text { Столяры-краснодеревщики и схожие мастера } \\
\text { Портные мужской и женской одежды, скорняки и шляпные мастера } \\
\text { Модельеры и закройщики одежды } \\
\text { Швеи, вышивальщицы и схожие мастера } \\
\text { Обойщики и схожие мастера } \\
\text { Кожевники, дубильщики и меховщики } \\
\text { Сапожники и схожие мастера } \\
\text { Мастера художественных промыслов, не классифицированные в других рубриках }\end{array}$ \\
\hline & $\begin{array}{l}\text { Образование/подготовка } \\
\text { кадров }\end{array}$ & $\begin{array}{l}2310 \\
2320 \\
2330 \\
2355\end{array}$ & $\begin{array}{l}7 \\
7 \\
7 \\
8\end{array}$ & $\begin{array}{l}\text { Преподаватели университетов и других высших учебных заведений } \\
\text { Преподаватели учебных заведений профессионального образования } \\
\text { Преподаватели средней школы } \\
\text { Другие преподаватели искусств }\end{array}$ \\
\hline
\end{tabular}




\begin{tabular}{|c|c|c|c|c|}
\hline \multirow{3}{*}{ Г. Книги и пресса } & Создание & 2641 & & Авторы и схожие специалисты \\
\hline & $\begin{array}{l}\text { Производство, } \\
\text { распространение }\end{array}$ & $\begin{array}{l}2642 \\
2643\end{array}$ & & $\begin{array}{l}\text { Журналисты } \\
\text { Устные и письменные переводчики и другие лингвисты }\end{array}$ \\
\hline & Архивирование/хранение & $\begin{array}{l}2622 \\
4411\end{array}$ & & $\begin{array}{l}\text { Библиотекари и связанные с ними специалисты в области информатики } \\
\text { Библиотечные работники }\end{array}$ \\
\hline \multirow{3}{*}{$\begin{array}{l}\text { Д. } \\
\text { Аудиовизуальные и } \\
\text { интерактивные } \\
\text { средства }\end{array}$} & Производство & $\begin{array}{l}2513 \\
2654 \\
2655 \\
3435\end{array}$ & 9 & $\begin{array}{l}\text { Разработчики веб-сайтов и мультимедиа } \\
\text { Режиссеры и постановщики театра и кино } \\
\text { Актеры } \\
\text { Другие профессионалы, связанные с искусством и культурой }\end{array}$ \\
\hline & Распространение & 2656 & & Дикторы и ведущие радио, телевидения и других средств информации \\
\hline & $\begin{array}{l}\text { Образование/подготовка } \\
\text { кадров }\end{array}$ & $\begin{array}{l}2310 \\
2320\end{array}$ & $\begin{array}{l}10 \\
10 \\
\end{array}$ & $\begin{array}{l}\text { Преподаватели университетов и других высших учебных заведений } \\
\text { Преподаватели учебных заведений профессионального образования }\end{array}$ \\
\hline \multirow{4}{*}{ 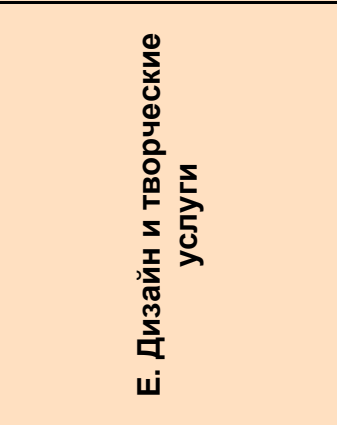 } & Создание & $\begin{array}{l}2161 \\
2162 \\
2163 \\
2164 \\
2165 \\
2166 \\
3432 \\
\end{array}$ & & $\begin{array}{l}\text { Архитекторы-строители } \\
\text { Ландшафтные архитекторы } \\
\text { Дизайнеры одежды } \\
\text { Специалисты по городскому и транспортному планированию } \\
\text { Картографы и топографы } \\
\text { Графические дизайнеры и дизайнеры мультимедиа } \\
\text { Дизайнеры интерьера и декораторы }\end{array}$ \\
\hline & Производство & 3118 & & Чертежники \\
\hline & Распространение & $\begin{array}{l}1222 \\
2431\end{array}$ & & $\begin{array}{l}\text { Управляющие по рекламе и связям с общественностью } \\
\text { Специалисты по рекламе и маркетингу }\end{array}$ \\
\hline & $\begin{array}{l}\text { Образование/подготовка } \\
\text { кадров }\end{array}$ & $\begin{array}{l}2310 \\
2320\end{array}$ & $\begin{array}{l}11 \\
11 \\
\end{array}$ & $\begin{array}{l}\text { Преподаватели университетов и других высших учебных заведений } \\
\text { Преподаватели учебных заведений профессионального образования }\end{array}$ \\
\hline
\end{tabular}

\section{Примечания:}

1 Включает археологов и хранителей.

2 Также включает профессионалов-управляющих в области музейного и архивного дела. При возможности, управляющие театров включены в

область Б - Представления и празднества.

3 Включает профессионалов, работающих в охраняемых областях.

4 Включает архивариусов, смотрителей музеев и картинных галерей.

5 Другие исполнители живых представлений (артисты мюзик-холлов, чревовещатели, тореадоры, чечеточники и т.п.); общинные работники культуры, клоуны, фокусники и т.п.

6 Следует включать учителей музыки в обычных школах.

7 Следует включать учителей визуальных искусств в обычных школах.

8 При возможности учителей танцев и руководителей театральных кружков следует включать в область Б - Представления и празднества.

9 Включает помощников кинорежиссеров, суфлеров, помощников режиссеров, актеров.

10 Следует включать учителей по аудиовизуальным и интерактивным средствам.

11 Следует включать учителей по дизайну и творческим услугам. 


\begin{tabular}{|c|c|c|c|c|}
\hline \multicolumn{5}{|c|}{ ПРОФЕССИИ ДОПОЛНИТЕЛЬНЫХ ОБЛАСТЕЙ } \\
\hline Область & Функция & $\begin{array}{l}\text { МСК3 } \\
08\end{array}$ & & Описание \\
\hline Ж. Туризм & Распространение & $\begin{array}{l}4221 \\
5111 \\
5113\end{array}$ & & $\begin{array}{l}\text { Сотрудники бюро путешествий и схожие профессии } \\
\text { Проводники и стюардессы } \\
\text { Гиды-сопровождающие }\end{array}$ \\
\hline \multirow{3}{*}{$\begin{array}{l}\text { 3. Спорт и } \\
\text { досуг }\end{array}$} & Производство & 3421 & & Спортсмены \\
\hline & Распространение & $\begin{array}{l}1431 \\
4212 \\
4213\end{array}$ & 12 & $\begin{array}{l}\text { Руководители спортивных и культурных центров, центров активного отдыха } \\
\text { Букмекеры, крупье и другие лица, работающие в сфере азартных игр } \\
\text { Ростовщики, ссужающие деньги под залог }\end{array}$ \\
\hline & Образование/подготовка кадров & $\begin{array}{l}3422 \\
3423\end{array}$ & & $\begin{array}{l}\text { Спортивные тренеры, инструкторы и чиновники } \\
\text { Инструкторы и руководители программ фризической подготовки }\end{array}$ \\
\hline
\end{tabular}

\section{Примечание:}

12 Включает руководителей парков развлечений и аттракционов. При возможности руководителей кинотеатров следует относить к области Д Аудиовизуальные и интерактивные средства. 


\begin{tabular}{|c|c|c|c|c|}
\hline \multicolumn{5}{|c|}{ СКВОЗНЫЕ ОБЛАСТИ* } \\
\hline Область & Функция & МСКЗ 08 & & Описание \\
\hline \multirow{3}{*}{$\begin{array}{l}\text { Нематериальное } \\
\text { культурное } \\
\text { наследие }\end{array}$} & Производство & $\begin{array}{l}1113 \\
2636 \\
3230 \\
5169\end{array}$ & 13 & $\begin{array}{l}\text { Традиционные вожди и старейшины селений } \\
\text { Священнослужители } \\
\text { Традиционные и вспомогательные профессии, связанные с медициной } \\
\text { Лица, оказывающие персональные услуги, не классифицированные в других рубриках }\end{array}$ \\
\hline & Распространение & 3413 & 14 & Профессионалы, связанные с религией \\
\hline & $\begin{array}{l}\text { Образование/подготовка } \\
\text { кадров }\end{array}$ & 2353 & & Другие преподаватели языков \\
\hline \multicolumn{5}{|c|}{ ОБОРУДОВАНИЕ И СОПУТСТВУЮЩИЕ МАТЕРИАЛЫ } \\
\hline $\begin{array}{c}\text { Визуальные } \\
\text { искусства и } \\
\text { художественные } \\
\text { промыслы } \\
\end{array}$ & Производство & $\begin{array}{l}7322 \\
7521 \\
7523 \\
8132 \\
\end{array}$ & & $\begin{array}{l}\text { Набойщики: с шелковых и наборных шаблонов, текстильщики (ручное производство) } \\
\text { Пропитчики древесины } \\
\text { Наладчики и операторы деревообрабатывающего оборудования } \\
\text { Операторы устройств продуктов фотографии }\end{array}$ \\
\hline Книги и пресса & Производство & $\begin{array}{l}7321 \\
7322 \\
7323 \\
\end{array}$ & 15 & $\begin{array}{l}\text { Техники по допечатке } \\
\text { Печатники } \\
\text { Рабочие по отделке и переплету }\end{array}$ \\
\hline \multirow[t]{3}{*}{$\begin{array}{l}\text { Аудиовизуальные } \\
\text { и интерактивные } \\
\text { средства }\end{array}$} & Производство & $\begin{array}{l}1330 \\
2511 \\
2512 \\
2514 \\
2519 \\
2523 \\
3511 \\
3512 \\
3513 \\
3514\end{array}$ & & $\begin{array}{l}\text { Управляющие по оказанию услуг в области информатики и коммуникаций } \\
\text { Системные аналитики } \\
\text { Разработчики программного обеспечения } \\
\text { Разработчики прикладного программного обеспечения } \\
\text { Разработчики и аналитики программного обеспечения и приложений, не классифицированные в } \\
\text { других рубриках } \\
\text { Специалисты по компьютерным сетям } \\
\text { Технические операторы информационных и коммуникационных технологий } \\
\text { Техники по поддержке пользователей информационными и коммуникационными технологиями } \\
\text { Техники по компьютерным сетям и системам } \\
\text { Техники компьютерной сети }\end{array}$ \\
\hline & Распространение & 3521 & & Техники по вещанию и аудиовизуальным средствам \\
\hline & $\begin{array}{l}\text { Образование/подготовка } \\
\text { кадров }\end{array}$ & 2356 & & Преподаватели информационных технологий \\
\hline
\end{tabular}

\section{Примечания:}

13 Включает лекарей, знахарей и целителей.

14 Включает знахарей, исцеляющих наговорами.

15 Включает наборщиков и рабочих смежных специальностей. 
Таблица 5. Опросы по использованию времени на основе категорий ICATUS

\begin{tabular}{|c|c|c|c|c|}
\hline \multicolumn{5}{|c|}{ ОБЛАСТИ КУЛЬТУРЫ } \\
\hline Функция & Область & ICATUS & & Описание \\
\hline \multirow{4}{*}{ 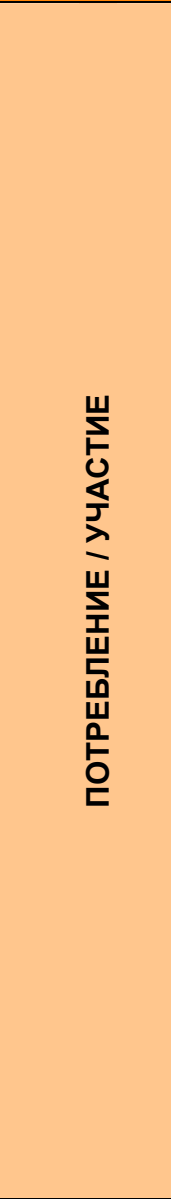 } & $\begin{array}{l}\text { А. Культурное и } \\
\text { природное } \\
\text { наследие }\end{array}$ & $\begin{array}{l}071135 \\
111110 \\
\end{array}$ & & $\begin{array}{l}\text { Организация экскурсий для детей, посещение музеев и аналогичные визиты; координация или содействие } \\
\text { общественной или внешкольной деятельности детей } \\
\text { Посещение музеев, картинных галерей, исторических/культурных парков, памятников культурного наследия }\end{array}$ \\
\hline &  & $\begin{array}{l}101210 \\
101230 \\
111130 \\
111190 \\
121130 \\
1211 x \\
141320 \\
141420\end{array}$ & $\begin{array}{c}2, * \\
3\end{array}$ & $\begin{array}{l}\text { Участие в праздновании общинных культурных/исторических событий } \\
\text { Участие в общинных общественных функциях (музыка, танцы и т.п.) } \\
\text { Посещение театров, оперы, балета, концертов } \\
\text { Посещение других массовых культурных мероприятий } \\
\text { Исполнительские искусства (танцы, музыка, театр) } \\
\text { Визуальные, литературные и исполнительские искусства, определение дано не полностью } \\
\text { Прослушивание других средств записи и воспроизведения звука } \\
\text { Использование аудиовизуальных средств компьютерных технологий }\end{array}$ \\
\hline &  & $\begin{array}{l}031141 \\
031142 \\
031143 \\
031144 \\
031145 \\
031146 \\
031147 \\
031149 \\
\mathbf{0 3 1 1 4 x} \\
031210 \\
031220 \\
121110\end{array}$ & $\begin{array}{l}4 \\
4 \\
4 \\
4 \\
4 \\
4 \\
4 \\
4 \\
*\end{array}$ & $\begin{array}{l}\text { Производство продуктов из дерева, включая мебель, принадлежности, приспособления, статуэтки и другие } \\
\text { украшения } \\
\text { Производство корзин, плетеных изделий и других аналогичных продуктов } \\
\text { Производство посуды, столовой утвари, ручных инструментов и других металлических продуктов } \\
\text { Обработка металла } \\
\text { Производство гончарных изделий, печей и кухонных печей, украшений и т.п. из глины, гипса или цемента } \\
\text { Производство бумаги и бумажных продуктов; крафт-бумаги } \\
\text { Производство мыла, парфюмерии, свечей и т.п. } \\
\text { Другая деятельность, связанная с художественными промыслами } \\
\text { Художественные промыслы с использованием всех типов материалов, определение дано не } \\
\text { полностью } \\
\text { Покупка/приобретение ресурсов/припасов, используемых в подсобной производственной деятельности } \\
\text { домашних хозяйств } \\
\text { Продажа/раздача продуктов подсобной производственной деятельности домашних хозяйств } \\
\text { Визуальные искусства }\end{array}$ \\
\hline & 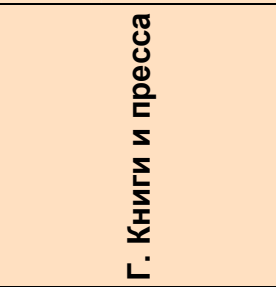 & $\begin{array}{l}121120 \\
141110 \\
141120 \\
141190 \\
1411 x \\
141320 \\
141410 \\
142000\end{array}$ & $\begin{array}{c}6 \\
6 \\
6 \\
7,{ }^{*} \\
8\end{array}$ & $\begin{array}{l}\text { Литература } \\
\text { Чтение книг } \\
\text { Чтение периодических изданий } \\
\text { Чтение других материалов } \\
\text { Чтение, определение дано не полностью } \\
\text { Прослушивание других средств записи и воспроизведения звука } \\
\text { Использование для чтения компьютерных технологий } \\
\text { Посещение библиотек }\end{array}$ \\
\hline
\end{tabular}






\begin{tabular}{|c|c|c|c|c|}
\hline \multicolumn{5}{|c|}{ ДОПОЛНИТЕЛЬНЫЕ ОБЛАСТИ } \\
\hline Функция & Область & ICATUS & & Описание \\
\hline \multirow{2}{*}{ 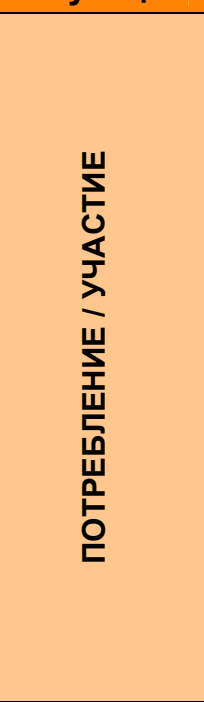 } & 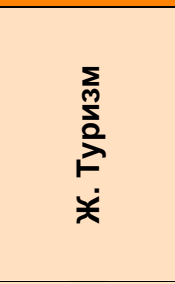 & $\begin{array}{l}102000 \\
112000 \\
122000 \\
131230 \\
132000 \\
143000\end{array}$ & & $\begin{array}{l}\text { Путешествия, связанные с общением и участием в жизни сообщества } \\
\text { Путешествя,, связанные с посещениями/визитами культурных, развлекательных и спортивных } \\
\text { событий/соревнований } \\
\text { Путешествия, связанные с увлечениями, играми и другими развлечениями } \\
\text { Развлекательные прогулки; осмотр достопримечательностей } \\
\text { Путешествия, связанные с участием в спортивных состязаниях и соревнованиях в закрытых и открытых } \\
\text { помещениях } \\
\text { Путешествия, связанные со средствами массовой инфоормации }\end{array}$ \\
\hline & 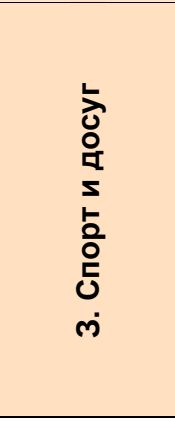 & $\begin{array}{l}071234 \\
071235 \\
111200 \\
111310 \\
111320 \\
111 x \\
119000 \\
129000 \\
121200\end{array}$ & $13,{ }^{*}$ & $\begin{array}{l}\text { Сопровождение взрослых на общественные мероприятия } \\
\text { Сопровождение взрослых на куьтурные, спортивные и развлекательные события } \\
\text { Посещения/визиты зопарков, ботанических садов, развлекательных центров, ярмарок, фестивалей, цирков, } \\
\text { выставок животных, выставок растений } \\
\text { Посещение профессиональных спортивных мероприятий } \\
\text { Посещение любительских спортивных мероприятий } \\
\text { Посещение культурных, развлекательных и спортивных мероприятий, определение дано не } \\
\text { полностью } \\
\text { Посещения/визиты спортивных, развлекательных и культурных мероприятий/событий, не классифицировано } \\
\text { в других рубриках } \\
\text { Увлчения, игры и другие развлечения, не классисфицировано в других рубриках } \\
\text { Технические увлечения и связанные с ними соревнования }\end{array}$ \\
\hline
\end{tabular}






\begin{tabular}{|c|c|c|c|c|}
\hline \multicolumn{5}{|c|}{ СКВОЗНЫЕ ФУНКЦИИ } \\
\hline Функция & Область & ICATUS & & Описание \\
\hline \multirow[t]{2}{*}{ 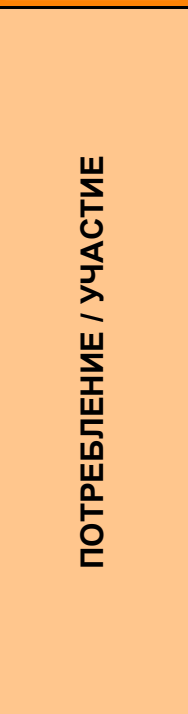 } & 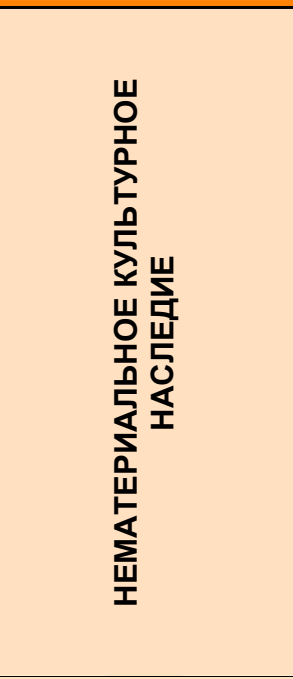 & $\begin{array}{l}031170 \\
071234 \\
\mathbf{0 7 1 2 3 x} \\
081210 \\
081230 \\
081240 \\
082000 \\
101124 \\
101125 \\
101126 \\
101129 \\
101210 \\
\\
101220 \\
101230 \\
\mathbf{1 0 1 2 x} \\
151510 \\
151520 \\
151630 \\
\end{array}$ & $\begin{array}{l}16 \\
17\end{array}$ & $\begin{array}{l}\text { Сбор целебных трав и производство медицинских препаратов } \\
\text { Сопровождение взрослых на общественные мероприятия } \\
\text { Сопровождение взрослых, определение дано не полностью } \\
\text { Организация общинных работ: приготовление пищи для коллективных празднеств и т.п. } \\
\text { Организация и работа по оказанию общинной помощи в селениях и других местах } \\
\text { Организация и работа по оказанию общинной помощи семьям и отдельным лицам } \\
\text { Посещение собраний } \\
\text { Приглашение гостей, организация приемов, аналогичные собрания } \\
\text { Выходы в гости, посещение приемов, аналогичные собрания } \\
\text { Общение в барах, клубах } \\
\text { Другие виды общения } \\
\text { Участие в общинных празднествах по случаю культурных/исторических событий } \\
\text { Участие в общинных церемониях/событиях (нерелигиозного характера), таких как свадьбы, похороны, } \\
\text { рождения и аналогичные регулярные события } \\
\text { Участие в общественных функциях сообщества (музыка, танцы и т.п.) } \\
\text { Участие в жизни сообщества } \\
\text { Индивидуальные молитвы, медитация и другая неформальная духовная деятельность } \\
\text { Участие в религиозных мероприятиях (формальная религиозная практика) } \\
\text { Размышления/медитация, раздумья, планирование }\end{array}$ \\
\hline & ОБРАЗОВАНИЕ ${ }^{19}$ & 091300 & 18 & Дополнительное обучение, неформальное обучение и курсы в свободное время \\
\hline
\end{tabular}




\section{Примечания:}

Значок «Х» указывает на необходимость включить все остальные виды деятельности, связанные с данной темой. Поскольку ICATUS является проектом, разработка некоторых категорий пока не закончена.

1 Исключение: неоплаченные услуги в отношении таких видов деятельности, как приготовление пищи, возведение сцены, организация, сбор пожертвований, подготовка костюмов и т.д. классифицируются в рубрике 08121.

2 Эта категория также охватывает литературу и визуальные искусства.

3 К аудио средствам относятся CD, пленочные, записывающие, MP3 плееры. Компьютерное прослушивание относится к категории 14142.

4 Включает все виды деятельности, связанной с экономической деятельностью в соответствующих разрядах МСОК 20, 21, 242, 26, 289, 36, таких как обработка и резьба по дереву, плетение корзин, сварка, изготовление кирпичей, производство инструментов.

5 Включает распродажи в гаражах или дворах кустарных изделий, продуктов питания и т.д., сделанных в свободное время или в качестве хобби.

6 Чтение с использованием компьютеров и аналогичных устройств классифицируется в разделе 14141. Исключение: чтение религиозных книг, связанное с религиозной практикой, относится к разделу 1515.

7 Включает чтение периодических издание, книг или других аналогичных изданий.

8 К аудио средствам относятся CD, пленочные, записывающие, MP3 плееры. Компьютерное прослушивание относится к категории 14142.

9 Использование телевизоров и видеозаписей исключительно для учебы и работы относится к разделам 01-05 или 09.

10 К видео средствам относятся видеомагнитофоны, проигрыватели видео компакт-дисков (VCD), цифровых видео дисков (DVD) и другие устройства, за исключением компьютеров. Компьютерный просмотр относится к категории 14142

11 Если известна цель навигации в Интернете, ей присваивается соответствующий код; например, если это касается покупок, навигацию следует отнести к категориям 06121 или 06122; оплату счетов за коммунальные услуги - к категории 06115; обучение, соответственно, к категории 09111 или 09113.

12 К этой категории относится сопровождение взрослых на культурные мероприятия.

13 Эта категория также охватывает культурные мероприятия.

14 Исключение: увлечения, приносящие доход в результате предоставления услуг или произведенных и проданных результатов относятся к соответствующим разделам категорий 02-05

15 Исключение: ставки в играх относятся к коду 12135.

16 Включает: все типы собраний и т.п., проводимых по инициативе общественных, политических, скаутских, религиозных, земляческих и других организаций, клубов и групп.

17 Исключение: неоплаченные услуги в отношении таких видов деятельности, как приготовление пищи, возведение сцены, организация, сбор пожертвований, подготовка костюмов и т.д. классифицируются в рубрике 08121.

18 Исключение: посещение курсов, связанных с увлечениями и оздоровительными спортивными играми, классифицируются в категориях 12 и 13 посещение курсов, связанных с профессиональным и карьерным ростом, относится к разделу 0914.

19 Подготовка кадров и обучение на курсах повышения квалификации в рамках профессиональной должности, классифицируется в категориях 01-05; курсы, связанные с увлечениями и спортом, относятся, соответственно, к категориям 12 и 13. 


\section{6. Заключение}

Система статистики культуры ЮНЕСКО 2009 представляет собой первый значительный шаг в направлении создания методологии и стандарта для организации статистики культуры, которая позволит получать данные, сопоставимые в международном плане. Работа ЮНЕСКО над ССК продолжается. Уже созданы некоторые инструменты для измерения экономических параметров культуры, но измерение ее социальных параметров требует дальнейших усилий по доработке. Предполагается, что ССК будет регулярно обновляться по мере развития методологии и углубления концептуального осмысления проблемы.

\section{1 Проблемы, связанные со сбором данных по культуре}

Учитывая недостаток собранных данных даже в тех странах, где на развитие статистических систем культурных отраслей выделялись время и средства, стоит кратко остановиться на некоторых основные проблемах, связанных со статистикой культуры.

\section{Структурные проблемы}

Поскольку политика и управление имеют тенденцию сосредотачиваться на деятельности, определяемой на основе их рынков (например, кинофильмы, телевидение, музыка), а наиболее распространенные статистические классификации (приспособленные к потребностям стран версии МСОК) разработаны в основном на базе классификационного принципа промышленного выпуска ${ }^{6}$ (например, производство печатных продуктов и их воспроизводство компьютерными средствами), трудно пытаться использовать эти классификации для описания культурных отраслей, ориентирующихся на требования рынка.

Что касается культуры, соответствующие категории рассредоточены по классификациям, и потому их надо искусственно перегруппировывать заново. Это непростая задача, требующая больших временных затрат.

Статистические системы промышленной классификации также стремятся учитывать происходящие в промышленности изменения. В них дается детальное описание традиционных областей экономики, таких как сырьевая и добывающая отрасли промышленности, и производство. Вместе с тем, сектор услуг в целом отражен недостаточно, причем слабее всего в классификациях представлены те области, в которых имеет место бурное технологическое и рыночное развитие; оба типа изменений создают трудности для применения пересмотренной системы статистики культуры, в которой принимается в расчет возрастающее влияние новых цифровых ИКТ.

6 Хотя главным принципом, лежащим в основе классификации, является выпуск, это не всегда соответствует ее задачам. В отдельных случаях классификационные принципы определяются процессом или используемым сырьем. 


\section{Операционные проблемы}

Обычно культурную деятельность можно точно определить в рамках статистических систем промышленной классификации только с самыми высокими уровнями разбивки по видам деятельности (категории с четырех- или пятизначными кодами). Это создает трудности, поскольку данные, предоставляемые национальными статистическими агентствами по источникам со многими переменными (например, экспорт), часто применимы лишь к отраслям промышленности на более низком уровне разбивки, обычно с категориями из двух- или трехзначных кодов.

Высокий уровень промышленной разбивки на категории, необходимый для точного определения видов культурной деятельности, имеет и другие последствия. Он делает детальный национальный анализ, - который особенно важен в культурной отрасли за счет тенденций агломерации, - проблематичным, поскольку комбинация четырехзначного анализа в рамках одной местности или региона снижает достоверность многих опросов хозяйственной деятельности, проводимых национальными статистическими агентствами (за счет проблем объема выборки). Кроме того, многие перекрестные экономические опросы хозяйственной деятельности имеют недостаточный охват малых $и$ индивидуальных предприятий, непропорционально представленных в отрасли культуры.

Существует несколько «обходных путей», которые можно использовать в тех случаях, когда культурная деятельность сочетается с другой деятельностью в отдельных областях. В частности, в этих областях можно использовать оценки, применяемые для отделения культурной составляющей от той, которая не является культурной, и эти соотношения или коэффициенты можно потом использовать при анализе данных опросов хозяйственной деятельности. Тем не менее, при этом должна быть определенная эмпирическая основа, на основании которой выводятся такие соотношения, что подразумевает наличие доступа к источнику данных, содержащих перечень всех хозяйств. Но и в этом случае - если предположить, что такое полный список хозяйств существует, - его анализ для разработки коэффициентов представляет собой задачу, требующую немалого времени и средств.

И, наконец, выработка данных о социальных аспектах культуры на том же уровне, что и данные, полученные национальными статистическим агентствами, также связана с рядом операционных проблем.

В этих целях можно применять отдельные результаты опросов из разных систем классификации, таких как обследования домашних хозяйств и использованного времени. Однако, в связи с ограничениями областей охвата таких опросов общего характера, данные этих источников могут быть недостаточными, чтобы обеспечить потребности процесса выработки политики в отношении социальных параметров культуры. Это может быть связано и с проблемами надежности, когда результаты обследований разбиты по определенным группам населения (например, по возрасту, полу, расовым или этническим группам), и особенно в тех случаях, когда требуется измерение изменений. Проблема надежности может затрагивать даже целевые обследования культурного участия, такие, как опрос «Евробарометр». Поскольку при его проведении выборка ограничивалась примерно 1000 респондентов на страну, была получена лишь контекстуальная инфрормация на уровне страны, а не более детальные и надежные данные, необходимые для выработки политики. 
Результаты будут иметь значение как для развивающихся, так и для развитых стран. Прежде всего, там следует пересмотреть данные национального уровня. Однако, поскольку основная доля занятости в сфрере культуры приходится на городские районы (и обычно сосредотачивается в крупных городах), было бы желательно детализировать пространственную разбивку.

Очевидно, что альтернативой использованию данных, собранных на основе существующих национальных статистических источников и/или более целенаправленных международных источников сведений, является проведение национальных опросов культурного участия. Следует отметить, что отчасти эти трудности не носят общий характер, скорее они связаны со сложностью самого процесса выработки политики в области культуры, в частности, степенью, в которой эти данные применяются в процессе принятия решений.

Получение и сбор данных сами по себе не являются процессом выработки политики в области культуры, но составляют основное условие для современного процесса публичного принятия решений, а также отчетности общественных институтов. В этом отношении, важную роль играют данные национальных переписей населения, переписи предприятий и любые данные участия/пользования, а также сведения по финансированию. Роль такой системы состоит в том, чтобы создать возможность для диалога между функциями политики, основанной на данных, теми, кто эти данные предоставляет, и отраслью культуры во всех ее разнообразных фрормах. Это необходимо понимать с самого начала процесса развития, включающего периодическое обновление данных, проверки и внесения необходимых изменений.

Можно предположить, что система станет исходным пунктом для развития более всесторонних статистических данных. Документ может составить основу для переговоров лиц, ответственных за принятие политических решений, специалистов-практиков и агентств, проводящих переписи населения.

\section{2 Связь с прямыми измерениями}

Важным следующим шагом станет развитие политики, основанной на системе (системах) показателей, и определении выборочных показателей по каждой области и виду деятельности, чтобы помочь измерять и проводить мониторинг культурных явлений и воздействия политики в области культуры. До настоящего времени общепринятые модели выработки политики в области культуры рассматривали экономическое измерение данной культуры в качестве косвенного следствия публичных инвестиций в эту культуру. Это привело к развитию ряда моделей, использующих для оценки воздействия культуры дедуктивный подход (например, модели «коэффрициентов») (Scanlon and Longley 1984, Myerscough 1988). Модель, выбранная для настоящей системы, прежде всего исходит из положения культуры в рамках процессов социально-экономического развития и воспроизводства. Это снижает чрезмерную зависимость от непрямых, косвенных $и$ сравнительно проблематичных методологий. Сдвиг от косвенных моделей или моделей «коэфрфициентов» для измерения результатов культурного развития к использованию прямых измерений процесса и результата дает возможность развивать подход для измерения воздействия культуры, при котором можно проводить сравнения в международном плане и по разным отраслям. 
Прямые измерения точнее и надежнее, если при сборе данных используется общая система (Pratt, 2001). Некоторые данные можно получить, применяя стандартные классификации (особенно Международную стандартную отраслевую классификацию или Классификацию основных продуктов). Прямые измерения могут включать такие экономические показатели, как оборот, инвестиции, продукция, экспорт и занятость, а также связанную с ними инфрормацию о финансировании общественного сектора, тесно связанную с такими измерениями. Кроме того, прямые измерения потребления и участия также можно проводить на основе общих обследований домашних хозяйств или индивидуальных опросов.

\section{Схема 4. Таблица показателей}

\begin{tabular}{|c|c|c|c|c|c|c|c|c|}
\hline & \multicolumn{6}{|c|}{ Области культуры } & \multicolumn{2}{|c|}{$\begin{array}{c}\text { Дополнительные } \\
\text { области }\end{array}$} \\
\hline &  & 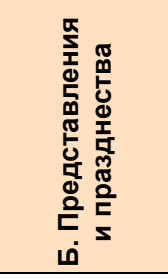 & 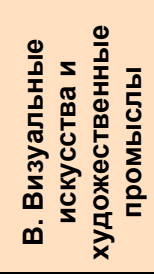 & 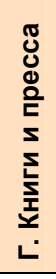 & 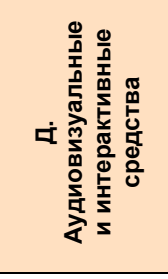 & 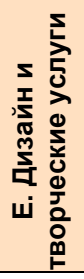 & 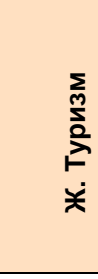 & 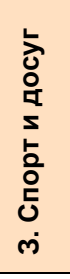 \\
\hline \multicolumn{9}{|l|}{ Создание } \\
\hline \multicolumn{9}{|l|}{ Производство } \\
\hline $\begin{array}{l}\text { Распространение/ } \\
\text { передача }\end{array}$ & & $\begin{array}{l}\text { Показатели } \\
\text {... }\end{array}$ & & & & & & \\
\hline $\begin{array}{l}\text { Демонстрация/ } \\
\text { восприятие }\end{array}$ & & & & & $\begin{array}{l}\text { Показатели } \\
\text {... }\end{array}$ & & & \\
\hline $\begin{array}{l}\text { Потребление/ } \\
\text { участие }\end{array}$ & & & & & & & & \\
\hline
\end{tabular}

Как показано на Схеме 4, один из подходов использует модель, основанную на таблице, в которой сведены восемь областей ССК и элементы культурного цикла. Эта модель была создана для развития и создания практичных и прагматичных средств сбора данных (в отличие от идеальных). В ее основе лежит работа группы ЕС ЭГЛ (LEG Eurostat, 2000) и опрос (логика) ряда существующих типов отражения данных. Она указывает на то, какие можно собирать данные, и аналогична предложенной в ССК 1986. В дальнейшем эта схема будет дорабатываться. Ее можно применять для прямых измерений, однако предполагается, что в будущем в нее войдут данные, которые в настоящее время не могут быть измерены. Важно отметить, что настоящая модель позволяет проводить международные сопоставления. Предложенную таблицу можно использовать при разных подходах к статистике культуры. 


\section{Глоссарий}

Авторское право - один из основных разделов интеллектуальной собственности. Оно касается «каждого продукта в области литературы, науки и искусства, независимо от способа или фрормы его выражения. Выражение "литературные и художественные произведения" в плане защиты авторских прав следует понимать как включающее любую оригинальную авторскую работу, независимо от ее литературных или художественных достоинств. Литературные и художественные произведения включают книги, памфлеты или иные произведения, музыку, пьесы, балет, фотографию, кинофрильмы, картины, рисунки, архитектуру, гравюру, литографию (WIPO, 2003, 1979).

Административное обследование - статистическое обследование, проводимое на основании источников, не связанных с данными статистических агентств, собранными с целями, не имеющими отношения к статистике (UNSC, 2000). Эти данные содержатся в картотеках и носят административный характер.

Архитектурные услуги предоставляются компаниями или лицами, имеющими отношение ко всем аспектам строительства. Прежде всего, эти услуги включают проектирование новых жилых, коммерческих и промышленных зданий, а также составление архитектурных планов для восстановления новых зданий и надзора за строительными работами.

Библиотека - это организация или часть организации, главные цели которой состоят в создании и поддержании фонда сведений и облегчении использования таких информационных ресурсов, которые удовлетворяют информационные, исследовательские, образовательные, культурные и развлекательные потребности его пользователей; эти основные требования к библиотеке не исключают любые дополнительные ресурсы и услуги, связанные с ее главной целью (ISO, 2006). Сюда включаются любые организованные собрания книг и периодических изданий в электронной или печатной форме, либо иных графических или аудиовизуальных материалах (изложено по: UNESCO, 1970), а также виртуальные библиотеки, цифровые каталоги.

Графический дизайн осуществляется компаниями или лицами, занятыми в основном дизайном графических материалов в целях демонстрации или публикации (Statistics New Zealand,1995). Он включает современные изделия кустарных промыслов.

Деятельность, связанная с дизайном интерьера, осуществляется компаниями и отдельными лицами, в основном связанными с дизайном внутреннего пространства частных и общественных, жилых и коммерческих зданий (Statistics New Zealand, 1995).

Дизайн состоит из элементов, в основном связанных с творческим, художественным и эстетическим дизайном предметов, окружающей среды и услуг.

Дизайн одежды определяется как произведенные товары и услуги, а также деятельность компаний или лиц, занятых в основном дизайном одежды, обуви и модных аксессуаров (Statistics New Zealand, 1995).

Досуг определяется как деятельность, которой занимаются для развлечения или расслабления, которая отвлекает, доставляет удовольствие или стимулирует. Она включает азартные игры и развлечения, но исключает физические упражнения, относимые к разделу Спорт. 
Изобразительные искусства связаны прежде всего с визуальным восприятием; они представляют собой виды искусства, сосредоточенные на создании произведений, в основном являющихся по природе визуальными или многомерными объектами.

Интерактивные средства можно определить как взаимодействующие в тех случаях, если либо (1) два или более объекта оказывают воздействие друг на друга; (2) пользователь может оказывать воздействие на объект или окружающую его среду (пользователи видеоигр); (3) они требуют активного вовлечения пользователя; или (4) существует двустороннее воздействие вместо одностороннего или простой причинно-следственной связи (Canadian Heritage, 2008).

Исполнительские искусства и празднества связаны с профеессиональной или любительской деятельностью в области таких исполнительских искусств, как театр, балет, опера и кукольный театр, а также с празднованиями культурных событий (фестивали, праздники и ярмарки), происходящих на местах, характер которых может быть неформальным.

Классификация основных продуктов (КОП) - система международного сравнения статистических данных, связанная с продуктами, служащими основным направлениям развития, или пересмотра существующих классификационных схем продуктов с целью сделать их сопоставимыми с международными стандартами. КОП была разработана в основном для повышения сопоставимости различных областей экономической и связанной с ней статистики, а также для повышения роли национальной отчетности в качестве инструмента для координации экономической статистики. Она создает основу для перекомпиляции исходных статистических данных из их первоначальных классификаций в стандартную классификацию для аналитического использования (UNSD, 2009).

Коренные и племенные народы. Племенные народы - это жители независимых стран, где социальные, культурные и экономические условия отличают их от других частей национального сообщества, и чей статус целиком или частично регулируется их собственными обычаями и традициями, либо специальными законами и постановлениями; племенные народы - это жители независимых стран, которые рассматриваются как коренные в силу их происхождения от населения, обитавшего в стране или географическом регионе, где расположена данная страна, в период завоевания или колонизации, либо установления современных государственных границ, и которые независимо от их юридического статуса сохраняют некоторые или все свои собственные социальные, экономические, культурные и политические институты» (ILO, 1989).

Культурная деятельность воплощает в себе или передает произведения культуры независимо от коммерческой цены, которую они могут иметь. Культурная деятельность может быть конечной целью сама по себе или вносить вклад в производство культурных товаров и услуг.

Культурная индустрия - производство и распределение культурных благ или услуг, как отмечено ниже.

Культурное наследие включает предметы материальной культуры, памятники, группы зданий и территории, обладающие различной ценностью, включая символическую, историческую, художественную, эстетическую, этнографическую или археологическую, и имеющие научное и общественное значение (UNESCO, 1972). 
Культурное разнообразие относится к способам, которыми выражается культура различных групп и обществ. Эти выражения культуры передаются в рамках и среди групп и обществ из поколения в поколение. Однако, культурное разнообразие проявляется не только через различные способы, которыми выражается, обогащается и передается культурное наследие, но также благодаря различным формам художественного творчества, производства, распределения, распространения и обладания независимо от того, какие при этом используются средства и технологии.

Культурные товары определяются как потребительские товары, передающие идеи, символы и представления об образе жизни, т.е. книги, журналы, продукты мультимедиа, программное обеспечение, музыкальные записи, кино, видеофильмы, аудиовизуальные программы, народные промыслы и мода.

Культурные услуги направлены на удовлетворение культурных интересов или потребностей. Сами по себе они не являются материальными культурными товарами, но облегчают их производство и распространение. Например, культурные услуги включают лицензионную деятельность и другие услуги, связанные с авторскими правами, распространением аудиовизуальной продукции, пропагандой исполнительских видов искусства и культурных мероприятий, а также культурные информационные услуги и хранение книг, записей и артефактов (в библиотеках, центрах документации, музеях).

Культурный ландшафт представляет собой объединенную работу природы и людей и выражает долгие и тесные отношения между людьми и естественной средой их обитания (UNESCO, 2007).

Культурный цикл охватывает культурное производство через ряд взаимосвязанных процессов или стадий, которые вместе образуют культурный цикл, цепочку добавленной стоимости или цепочку предложения.

Кустарные продукты или продукты народных промыслов определяются как продукты, которые «произведены ремесленниками либо полностью вручную, либо с помощью ручных инструментов, или даже механическими средствами, но лишь в том случае, если непосредственный ручной вклад ремесленника остается основной составляющей готового изделия. Особая природа кустарных продуктов определяется их характерными чертами, которые могут носить утилитарный, эстетический, художественный, творческий, связанный с культурой, декоративный, функциональный, традиционный, религиозный и общественно символический и значимый характер» (UNESCO-ITC, 1997).

Ландшафтный дизайн охватывает дизайн земель и садов, которыми пользуются люди. Обычно он связан с дизайном участков, примыкающих к частным или общественным зданиям, но может относиться и к большим общественным пространствам, таким как парки и заповедники (Statistics New Zealand, 1995).

Международная стандартная отраслевая классификация (МСОК) предназначена стать стандартной классификацией всей производственной деятельности. Ее главная задача состоит в предоставлении комплекса типов деятельности, который может быть использован для сбора и представления статистических данных в соответствии с этими видами деятельности. Поэтому МСОК стремится представить этот комплекс типов деятельности таким образом, чтобы их можно было классифицировать в соответствии с экономической деятельностью, которую они воплощают (UNSD, 2008). 
Музеи. Некоммерческие постоянные институты, служащие обществу и целям его развития, открытые для публики, приобретающие, хранящие, исследующие, передающие и демонстрирующие материальное и нематериальное наследие человечества и его окружающей среды в целях образования, изучения и развлечения. Сюда входят музеи под открытым небом.

а. Приведенное выше определение музея применимо без всяких ограничений, которые могут возникнуть в связи с природой руководящей организации, территориальным характером, структурой функционирования или ориентацией коллекций данного института.

б. В дополнение к институтам, определяемым как «музеи», к их числу относятся следующие учреждения:

i. Естественные, археологические и этнографические памятники и территории, исторические памятники и места, имеющие характер музеев, которые приобретают, сохраняют и передают материальные памятники человечества и окружающей его среды;

ii. Организации, имеющие и экспонирующие живые образцы животных и растений, такие как ботанические и зоологические сады, аквариумы и виварии;

iii. Научные центры и планетарии;

iv. Некоммерческие художественные галереи;

v. Заповедники, заказники, постоянные выставки, проводимые библиотеками и архивами, и природные парки;

vi. Международные, национальные, региональные или местные музейные организации, министерства, управления или общественные учреждения, ответственные за музеи в том их определении, которое здесь дано;

vii. Некоммерческие институты или организации, занимающиеся исследованиями хранения, образованием, подготовкой кадров, документацией и другой деятельностью, связанной с музеями и музейным делом;

viii. Культурные центры и другие организации, облегчающие хранение, преемственность и управление материальными или нематериальными ресурсами культурного наследия (как самого наследия, так и связанной с ним цифровой творческой деятельности); и

ix. Такие иные институты, которые Исполнительный совет после одобрения Экспертной комиссии сочтет имеющими некоторые или все характеристики музея, либо содействующие музеям и музейному персоналу в области музейных исследований, образования или подготовки кадров (ICOM 2007).

Нематериальное культурное наследие определяется как «обычаи, представления, творчество, знания, опыт - а также инструменты, предметы, артефракты и связанное с ними культурное пространство, - которые сообщества, группы, а в некоторых случаях отдельные лица признают частью своего культурного наследия. Нематериальное культурное наследие, передаваемое из поколения в поколение, постоянно воспроизводится общинами и группами в соответствии с изменениями окружающей среды, их взаимодействием с природой и историей, и дает им ощущение самобытности и непрерывности, тем самым обеспечивая уважение к культурному разнообразию $и$ человеческому творчеству» (UNESCO, 2003). 
Неформальный сектор в широком плане охватывает небольшие производственные единицы с низким уровнем организации при незначительном или отсутствующем разделении между трудом и капиталом как факторами производства, главной целью которого является получение дохода и занятости людей, которые там работают. Для удобства этот сектор определяется на основе национального подхода как некорпоративные предприятия, принадлежащие домашним хозяйствам, которые производят на рынок какую-либо продукцию, но не имеют достаточного числа занятых и/или не зарегистрированы в соответствии с данным национальным законодательством или постановлениями, относящимся, в частности, к обязательствам или нормативным актам по уплате налогов или социальному обеспечению (OECD, 1993).

Обследование рабочей силы является стандартным опросом домашних хозяйств, связанным со статистикой занятости (ILO).

Опрос общественного мнения - выборочный опрос, имеющий целью выяснить или установить мнения членов данного сообщества людей в отношении определенных проблем (OECD, 2008).

Опросы по расходам домашних хозяйств представляют собой выборочные опросы, в ходе которых ответственных за домашние хозяйства просят представить данные или оценки расходов на потребительские товары и услуги, а также другие цели, за определенный период. Их также называют опросами потребления домашних хозяйств или опросами бюджетов домашних хозяйств (OECD, 2008).

Переписи населения - проводятся по всему кругу вопросов, связанных с данным населением или генеральной совокупностью (UNSC, 2000).

Природное наследие состоит из естественных объектов, географических и фризикогеографических отложений, районов, считающихся территорией обитания животных и растений, которым угрожает исчезновение, а также природных зон, имеющих значение с точки зрения науки, сохранения или естественной красоты. Оно включает природные парки и заповедники, зоопарки, аквариумы и ботанические сады (UNESCO, 1972).

Реестр фирм - список, содержащий названия предприятий (UNSC, 2000).

Рекламные услуги предоставляются компаниями или лицами, в основном занятыми планированием, разработкой и проведением рекламных кампаний.

Сохранение. Цель сохранения состоит в том, чтобы избежать ущерб, который может быть нанесен условиями окружающей среды или случайными фракторами, угрожающими непосредственному окружению сохраняемого предмета. Соответственно, превентивные методы и средства обычно применяются не непосредственно, а через контроль микроклиматических условий окружающей среды с целью устранения вредных веществ или элементов, которые на временной или постоянной основе могут вызывать повреждение предмета (UNESCO, 1988).

Спорт и фризические упражнения включает компании и лиц, в основном занятых предоставлением или оказанием услуг в области спорта, фризического восстановления и т.п. Сюда включаются услуги тренеров и образовательные услуги в области фризической подготовки, а также компании, производящие и торгующие оптом $и$ в розницу спортивными товарами и принадлежностями для фризического восстановления. 
Традиционные знания «относятся к знаниям, новшествам и обычаям коренных народов и местных общин во всем мире. Традиционные знания, обретенные на основе опыта, полученного на протяжении столетий и приспособленного к местной культуре и окружающей среде, передаются в устной форме из поколения в поколение. Обычно они имеют коллективную принадлежность и принимают форму рассказов, песен, фольклора, пословиц, культурных ценностей, верований, ритуалов, законов сообществ, местного языка и сельскохозяйственных обычаев, включая разведение растений и животных. Традиционные знания носят в основном практический характер, в частности, в области сельского хозяйства, рыбной ловли, здоровья, садоводства, лесного хозяйства и регулирования природопользования в целом» (SCBD, 2007).

Участие в культурной жизни - это участие в деятельности, связанной с искусством, и повседневной деятельности, связанной с определенной культурой. Оно касается «способов, которыми различия этнического характера в культурных вкусах, ценностях и поведении проявляются не просто как художественные и информационные предпочтения, но заложены в повседневный ритм жизни; а также

способов, которыми они связаны с другими значимыми социальными характеристиками, например, такими, как класс и пол» (Bennett, 2001).

Хранение - меры по продлению жизни культурного наследия с целью усиления его свойств, передающих значимые послания и ценности наследия (ICCROM, 1998). В области культурной собственности цель сохранения состоит в поддержании физических и культурных характеристик объекта, чтобы его ценность не снижалась и он сохранился для будущего (UNESCO, 1988). 


\section{Библиография}

African Union (AU) (2005). Nairobi Plan of Action for Cultural Industries, at the First Ordinary Session of African Union Conference of Ministers of Culture, 10-14 December 2005, Nairobi, Kenya.

African Union (AU) (2008). Plan of Action on the Cultural and Creative Industries in Africa. Second Session of Conference of African Union Ministers of Culture, 19-23 October 2008, Algiers, Algeria.

Australian Bureau of Statistics (ABS) (2001). Australian Culture and Leisure Classifications. Adelaide.

Australian Bureau of Statistics (ABS) (2002). ABS Culture, Sport and Recreation Statistics: Current Activities and Future Strategy. Adelaide.

Australian Bureau of Statistics (ABS) (2006). Discussion paper: Arts and Cultural Heritage in Australia Key issues for an information development Plan. Adelaide.

Australian Bureau of Statistics (ABS) and Statistics New Zealand (2009). ANSZCO Alternative View Culture and Leisure Occupations in Australian and New Zealand Standard Classification of Occupations. First Edition, Revision 1. http://www.abs.gov.au/AUSSTATS/

abs@.nsf/DetailsPage/1220.0First\%20Edition,\%20Revision\%201?OpenDocument

Barrowclough, D. and Z. Kozul-Wright (Eds.) (2006). Creative Industries and Developing Countries: Voice, Choice and Economic Growth. London.

Bennett, Tony (2001). Differing Diversity: Cultural Policy and Cultural Diversity. Strasbourg: Council of Europe Publishing.

BIMSTEC countries (2006). Paro initiative and Plan of Actions, at the First BISMTEC on Cultural Cooperation, Paro, Bhutan, May 2006.

Canadian Heritage (2008). (not publicly available) Comments on the UNESCO FCS Draft 2007.

Caribbean Regional Negotiating Machinery (2006). The cultural industries in CARICOM: trade and development challenges.

Centre for Cultural Policy Research (2003). Baseline Study on Hong Kong's Creative Industries. Central Policy Unit, Hong Kong Special Administrative Region Government: University of Hong Kong.

Centre for Cultural Policy Research, Home Affairs Bureau (2005). A study on creativity index. Home Affairs Bureau, Hong Kong Special Administrative Region Government: University of Hong Kong.

Centro de Estudios Regionales Cafeteros y Empresaiales (2005). Guide for Drawing up Regional Mapping of Creative Industries. Bogota.

Christensen, L. et al (2001). Refuge for Integration: A Study of How the Ethnic Minorities in Denmark Use the Libraries. Moellegade: Aarhus Public Libraries, pp.1-23. http://www.aakb.dk/graphics/pub/refuge.pdf.

Convenio Andres Bello (2004). La fiesta, la otra cara del patrimonio. Valorización de su impacto económico, cultural y social. Economía and cultura 8. Bogota D. C. Colombia

Council for Cultural Affairs (2004). Cultural Policy White Paper. Taiwan Council for Cultural Affairs.

Cunningham, S. (2003). The Evolving Creative Industries. Transcript of a seminar, 9 May 2003. Brisbane: QUT.

Cunningham, S. and Peter Higgs (2008). Creative Industries Mapping: Where have we come from and where are we going? In Creative Industries Journal, Vol. 1, No. 1, Hockley, United Kingdom.

Department of Culture Media and Sports, United Kingdom (DCMS) (2001). Creative Industries Mapping Document. London: Department of Culture, Media and Sport. 
DCMS (2003). Regional Data Framework for the Creative Industries: Final Technical Report for the Department of Culture, Media and Sport and the Regional Cultural Consortia. London: Department of Culture, Media and Sport.

Economic Review Committee, Services Subcommittee Workgroup on the Creative Industries (2002). Creative Industries Development Strategy: Propelling Singapore's Creative Economy.

European Commission (2001). Report by the Task Force on Cultural Expenditure and Finance. Luxembourg.

European Commission, Eurostat (2002). European's Participation in Cultural Activity: A Eurobarometer Survey, Executive Summary.

European Commission (2006). The economy of culture in Europe. Luxembourg.

Eurostat, OECD, UN and UNWTO (2001). Tourism Satellite Account: Recommended Methodological Framework. www.world-tourism.org.

Eurostat. (2007). Eurostat Pocket book: Cultural statistics, European communities. Luxembourg.

Girard, A. (1982). Creative Industries: A Challenge for the Future of Culture. Paris: UNESCO.

Girard, A. (1982a). "Cultural industries: A handicap or a new opportunity for cultural development?" In UNESCO, Cultural Industries: A Challenge for the Future of Culture, pp. 24-39. Paris: UNESCO.

Gupta, A. and J. Ferguson (Eds.) (1999). Culture, Power, Place: Explorations in Critical Anthropology. Durham, North Carolina: Duke University Press.

Held, T., C. Kruse, M. Sondermann and A. Weckerle (2005). Zurich's Creative Industries Synthesis Report. Zurich: Office for Economy and Labour of the Canton of Zurich and City of Zurich Economic Development.

Hoehn, J., and A. Randall (1989), 'Too Many Proposals Pass the Benefit Cost Test', The American Economic Review, Vol. 79.3, pp. 544-551.

Hui, D. (2005). "Learning from Mapping Exercises: from Baseline Study to Creativity Index", paper presented to the conference "Asia Pacific Creative Communities: A Strategy for the $21^{\text {st }}$ Century", UNESCO Senior Expert Symposium on Cultural Industries, Jodhpur, India, 22-26 February 2005.

Inter American Development Bank (IABD) (2007), Cultural Industries in Latin America and the Caribbean: Challenges and Opportunities, Washington: IABD.

International Center for the Study of the Preservation and Restoration of Cultural Property (ICCROM). (1998). Risk Preparedness: A Management Manual for World Cultural Heritage. Roma: ICCROM, 1998.

International Council of Museums (ICOM, 2007). Article 3, Statutes, adopted by the 22nd General Assembly, Vienna, Austria, 24 August 2007.

International Labour Organisation (ILO) (1988). International Standard Classification of Occupations, ISCO 88. Geneva: ILO.

ILO (1989). Indigenous and Tribal Peoples Convention, (No. 169). Geneva: ILO.

ILO (2008). International Standard Classification of Occupations, ISCO 08.

International Standard Organisation (ISO) (2006). 2789, Information and documentation - International library statistics.

International Monetary Fund (2008). Balance of Payments and International Investment Position Manual, Six Edition (BPM6), pre-publication draft. December 2008. Statistics Department, IMF.

Keaney, E. (2006). From Access to Participation: Cultural Policy and Civil Renewal. London: IPPR. 
LEG Eurostat (2000). "Cultural statistics in the EU", Eurostat Working Paper; Population and Social Conditions Series, 3/2000/E/No1. Final report of the LEG. Luxembourg.

Manninen, A. (2002). Cultural Consumption and Practices: A National and Cross-National Perspective. City of Helsinki, Department of Urban Facts. Proceedings of the International Symposium on Culture Statistics, UNESCO Institute for Statistics, Montreal, 21-23 October 2002.

Michalos, A. (2003). Essays on the Quality of Life, Social Indicators Research Series, Vol. 19. Kluwer, Dordrecht.

Michalos, A. (ed.) (2005). Citation Classics from Social Indicators Research: The most cited articles, Social Indicators Research Series, Vol. 26. Springer, Dordrecht.

Ministry of Cultural Affairs, Statistics New Zealand (1995). New Zealand Framework for Cultural Statistics 1995.

Ministry of Cultural Affairs, Statistics New Zealand (1996). Household Spending on Culture.

Ministry for Culture and Heritage, Statistics New Zealand (2003). A Measure of Culture: Cultural Experiences and Cultural Spending in New Zealand.

Ministry for Culture and Heritage, Statistics New Zealand (2005). Employment in the Cultural Sector 2005.

Ministry of Education (1998). Cultural Industry Committee Final Report. Helsinki: Ministry of Education.

Myerscough, J. (1988). The Economic Importance of the Arts in Britain. London: Policy Studies Institute.

Navrud, S. and Richard C. Ready (2002). Valuing Cultural Heritage: Applying Environmental Valuation Techniques to Historic Buildings, Monuments and Artefacts. London: Edward Elgar Publishing Ltd.

Observatoire de la culture et des communications du Québec (2003). Québec Culture and Communications Activity Classification System 2004. Québec City: Institut de la statistique du Québec.

Observatory of Cultural Policies in Africa (OCPA), Interarts, UNESCO (2004). Cultural Indicators of Human Development in Africa, final report, International Seminar, Maputo 3-5 March 2004.

Observatory of Cultural Policies in Africa (OCPA). (2006) Indicateurs culturels pour le développement humain en Afrique, projet de recherche. Maputo

OECD (1993). The System of National Accounts, 1993 - Glossary. Paris: OECD.

OECD (2007). International Measurement of the Economic and Social Importance of Culture. Paris.

OECD (2008). OECD Glossary of Statistical Terms.

Organisation Internationale de la Francophonie (OIF) (2002). Les industries culturelles des pays du Sud: Enjeux du projet de convention internationale sur la diversité culturelle.

Pratt, A. C. (2001). "Understanding the cultural industries: Is more less?" Culturelink 35, pp. 51-68.

Pratt, A. C. and N'deck Ndiaye (2004). The Music Industry in Senegal: The Potential for Economic Development, report for UNCTAD. London.

Scanlon, R. and R. Longley (1984). "The arts as an industry: the economic importance to the New YorkNew Jersey Metropolitan Region" in W. Hendon, D. Shaw and N. Grant (Eds.) The Economics of Cultural Industries, pp. 93-100. Association for Cultural Economics, United States of America: University of Akron.

Secretariat of the Convention on Biological Diversity (SCBD) (2007). "Article 8(j): Traditional knowledge and the convention on biological diversity". Montreal. http://www.cbd.int/programmes/socioeco/traditional/default.shtml 
Secretariat of the Pacific Community (SPC) (2002). Regional Framework for the Protection of Traditional Knowledge and Expressions of Culture.

Sen Amartya (2000). Culture and development. World Bank Tokyo Meeting, 11-13 December 2000.

Siwek S. (2002). Copyright Industries in the U.S. Economy: The 2002 Report. Washington, D.C: The International Intellectual Property Alliance.

South African Cultural Observatory. The Economics of Culture and Cultural Statistics in South Africa : http://www.culturalobservatory.org.za/pdf_files/econ_of_culture.pdf

Statistics Canada (1997). Canada's Culture, Heritage and Identity: A Statistical Perspective. Ottawa: Statistics Canada.

Statistics Canada (1998). Quality Guidelines. 12-539-XIE. Third Edition, October 1998.

Statistics Canada. (2004a) Culture, Tourism and the Centre for Education Statistics. Canadian Framework for Culture Statistics. Ottawa: Statistics Canada.

Statistics Canada. (2004b) Culture, Tourism and the Centre for Education Statistics. Economic Contribution of Culture in Canada. Ottawa: Statistics Canada.

Statistics Canada. (2004c) Culture, Tourism and the Centre for Education Statistics. Economic Contribution of the Culture Sector in Canada - A Provincial Perspective. Ottawa: Statistics Canada.

Statistics Finland (2005). Cultural Statistics [Online] (http://www.stat.fi/til /klt_en.html).

Statistics Finland (2005). Leisure Survey [Online] (http://www.stat.fi/til /klt_en.html).

Statistics Finland (2006). Mass Media [Online] (http://www.stat.fi/til/klt_en.html).

Statistics Finland (2006). Mass Media Market 2000 - 2004 [Online] (http://www.stat.fi/til/klt_en.html).

Statistics Finland (2006). Time Use Survey [Online] (http://www.stat.fi/til /klt_en.html).

Statistics New Zealand (2000). Government Spending on Culture - article [Online]

(http://stats.gov.nz/products-and-services/Articles/spemd-on-cult-90-99).

Statistics New Zealand (2003). Cultural Experience Survey [Online] (http://stats.gov.nz/NR/exeres).

Steinberg, C. (2001). "Culture and sustainable tourism". Recognising culture: a series of briefing papers on culture and development. Comedia, Department of Canadian Heritage, UNESCO.

Thorhauge, J. (2003). "Danish Strategies in Public Library Services to Ethnic Minorities", paper prepared for the World Library and Information Congress: $69^{\text {th }}$ IFLA General Conference and Council, Berlin, 1-9 August 2003.

Throsby, David. (2001). Economics and culture. Cambridge University Press.

Throsby, David. (2005). On the Sustainability of Cultural Capital. Research Papers No. 510, Sydney: Macquarie University.

Uganda, Ministry of Gender Labour and Social Development (2006). Uganda national culture policy. Kampala.

United Nations (2002). European Commission, IMF, OECD, UNCTAD, WTO. Manual on Statistics of International Trade in Services. Statistical Papers, Series M No 86.

United Nations (2005). A Guide to Producing Statistics on Time Use: Measuring Paid and Unpaid Work. Department of Economic and Social Affairs Statistics Division. New York: United Nations.

United Nations (2007). Principles and Recommendations for Population and Housing Censuses Revision 2. Statistical Papers, Series M No 67/Rev2. Department of Economic and Social Affairs Statistics Division. United Nations, New York. 
United Nations Statistics Division (UNSD) (2008). International Standard Industrial Classification of All Economics Activities (ISIC), Revision 4. Statistical Papers: Series M, No 4, Rev. 4. United Nations. New York.

United Nations Statistics Division (UNSD) (1998). Trial International Classification of Activities for TimeUse Statistics. International Conference on Time Use, University of Luneberg, 22-25 April 1998.

United Nations Statistics Division (UNSD) (2009). Central Product Classification, Version 2. http://unstats.un.org/unsd/cr/registry/cpc-2.asp

UNCTAD/WIPO (2001). Developing Countries Becoming a Global Player: Opportunities in the Music Industry. Cuban Music Industry Development and Marketing Plan. Geneva: UNCTAD/ WIPO.

United Nations Development Programme (UNDP, 2005). Human Development report 2004: Cultural Liberty in Today's Diverse World. New York: UNDP.

UNESCO (1970). Recommendation concerning the International Standardization of Library Statistics. Records of the General Conference Sixteenth Session Paris, 12 October to 14 November 1970.

UNESCO (1972). Convention Concerning the Protection of the World Cultural and Natural Heritage. Paris: UNESCO.

UNESCO (1986). The UNESCO Framework for Cultural Statistics. Statistical Commission and Economic Commission for Europe, UNESCO, Conference of European Statisticians. Third Joint Meeting on Cultural Statistics, 17-20 March 1986. CES/AC/44/11. 13 February 1986.

UNESCO (1988). Traditional restoration techniques: a RAMP study. Paris: Unesco, 1988.

UNESCO. (1992) Culture industries for development in Africa: Dakar plan of action, Organization of African Unity. Dakar.

UNESCO (1995). Our creative diversity. Report of the World Commission on Culture and Development. Paris: UNESCO.

UNESCO (1997), Methodological Guide to the Collection of Data on Crafts.

UNESCO (1999). The value of culture. Paper for the Forum Development and Culture. IADB-UNESCO, Paris 11-12 March 1999.

UNESCO (2001). UNESCO Universal Declaration on cultural diversity. Paris: UNESCO.

UNESCO (2003a). Atelier sur la culture et le développement dans le programme d'action du NEPAD.

UNESCO (2003b). Convention for the Safeguarding of the Intangible Cultural Heritage. Paris: UNESCO.

UNESCO (2003c). Language Vitality and Endangerment, Paris: UNESCO.

UNESCO (2005a). Convention on the Protection and Promotion of the Diversity of Cultural Expressions. Paris: UNESCO.

UNESCO (2005b). Diagnóstico y metodología para diseñar indicadores culturales en los países centroamericanos. Documento de Trabajo, Seminario subregional sobre indicadores culturales en Centroamérica, San José Costa Rica, 6-8 de septiembre de 2005. Oficina de la UNESCO en México.

UNESCO (2007). World Heritage: [Online] http://whc.unesco.org/en/culturallandscape/

UNESCO (2008). La cultura en números: hacia un sistema de indicadores culturales para Centroamérica. UNESCO San José: CECC. San José, Costa Rica.

UNESCO (2009a). Culture sector.

http://portal.unesco.org/culture/en/ev.php-URL_ID=35263\&URL_DO=DO_TOPIC\&URL_SECTION=201.html

UNESCO (2009b). UNESCO's Atlas of the World's Languages in Danger, New Edition. http://portal.unesco.org/en/ev.php-URL_ID=44605\&URL_DO=DO_TOPIC\&URL_SECTION=201. html 
UNESCO-UIS (2005). International Flows of Selected Cultural Goods and Services, 1994-2003. Montreal: UNESCO Institute of Statistics.

UNESCO-UIS (2006a). Creating Global Statistics for Culture: Expert Scoping Study. Paper submitted to the UIS by BOP Consulting.

UNESCO-UIS (2006b). Guidelines for Measuring Cultural Participation. Paper submitted to the UIS by Adolfo Morrone. Montreal: UNESCO Institute of Statistics.

UNESCO-UIS (2006c). Evaluating Language Statistics: The Ethnologue and Beyond. Paper submitted to the UIS by John C. Paolillo. Montreal: UNESCO Institute for Statistics.

UNESCO-UIS (2006d Re-edition). International Standard Classification of Education (ISCED97). Montreal: UNESCO Institute of Statistics.

UNESCO-UIS (2007). Draft Revised 2009 Framework for Cultural Statistics. Montreal: UNESCO Institute of Statistics.

UNESCO International Trade Centre (UNESCO-ITC) (1997). International Symposium on "Crafts and the International Market: Trade and Customs Codification", Manila.

United Nations Statistical Commission (UNSC) and Economic Commission for Europe (ECE). (2000). Terminology on Statistical Metadata. Conference of European Statisticians Statistical Standards and Studies - No. 53. UN, New York.

Wallis, R. (2001). Best Practice Cases in the Music Industry and their Relevance for Government Policies in Developing Countries, report for WIPO-UNCTAD.

Williams, R. (1977). Marxism and literature. London: Oxford University Press.

World Intellectual Property Organisation (WIPO) (1957). International Classification of Goods and Services for the Purposes of the Registration of Marks under the Nice Agreement. Geneva: WIPO.

WIPO (1971). International Patent Classification. Geneva: WIPO.

WIPO (1979). Berne Convention for the Protection of Literary and Artistic Works. WIPO Database of Intellectual Property WIPO Legislative Texts. Geneva.

WIPO (2003). Guide on Surveying the Economic Contribution of the Copyright-based Industries. Geneva: WIPO.

World Tourism Organization (UNWTO) (2004). Indicators of Sustainable Development for Tourism Destinations, a Guidebook. Madrid: UNWTO. 


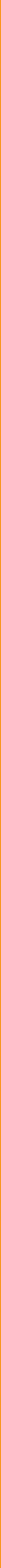

